\title{
Article
}

\section{South Asian mobilisation in two northern cities: a comparison of Manchester and Bradford Asian youth movements}

\author{
Ramamurthy, Anandi
}

Available at http://clok.uclan.ac.uk/2096/

Ramamurthy, Anandi (2011) South Asian mobilisation in two northern cities: a comparison of Manchester and Bradford Asian youth movements. Ethnicity and Race in a Changing World, 2 (2). pp. 26-42. ISSN 1758-8685

It is advisable to refer to the publisher's version if you intend to cite from the work.

For more information about UCLan's research in this area go to http://www.uclan.ac.uk/researchgroups/ and search for < name of research Group>.

For information about Research generally at UCLan please go to http://www.uclan.ac.uk/research/

All outputs in CLoK are protected by Intellectual Property Rights law, including Copyright law. Copyright, IPR and Moral Rights for the works on this site are retained by the individual authors and/or other copyright owners. Terms and conditions for use of this material are defined in the policies page.

\section{CLoK}

Central Lancashire online Knowledge www.clok.uclan.ac.uk

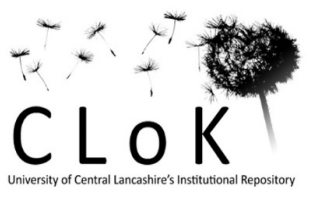




\section{Ethnicity and Race in a Changing World: A Review Journal}

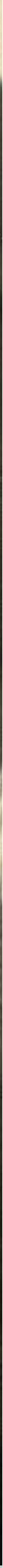

Volume 2

Issue 2

Winter 2011 
While copyright in the journal as a whole is vested in Manchester University Press, copyright in individual articles belongs to their respective authors and no chapters may be reproduced wholly or in part without the express permission in writing of both author and publisher. Articles, comments and reviews express only the personal views of the author.

Published by Manchester University Press, Oxford Road, Manchester, M13 9NR

www.manchesteruniversitypress.co.uk

ISSN $1758-8685$

Ethnicity and Race in a Changing World: A Review Journal is a biannual journal, semi peer reviewed and freely available online.

Those planning to submit to the journal are advised to consult the guidelines found on the website.

The journal is created and edited by the Ahmed Iqbal Ullah Race Relations Resource Centre, University of Manchester, J Floor, Sackville Street Building, Sackville Street Area, M60 1OD

Telephone: 01612752920

Email: racereviewjournal@manchester.ac.uk 


\title{
Ethnicity and Race in a Changing World:
}

A Review Journal

\author{
Volume 2 \\ Issue 2 \\ Winter, 2011
}




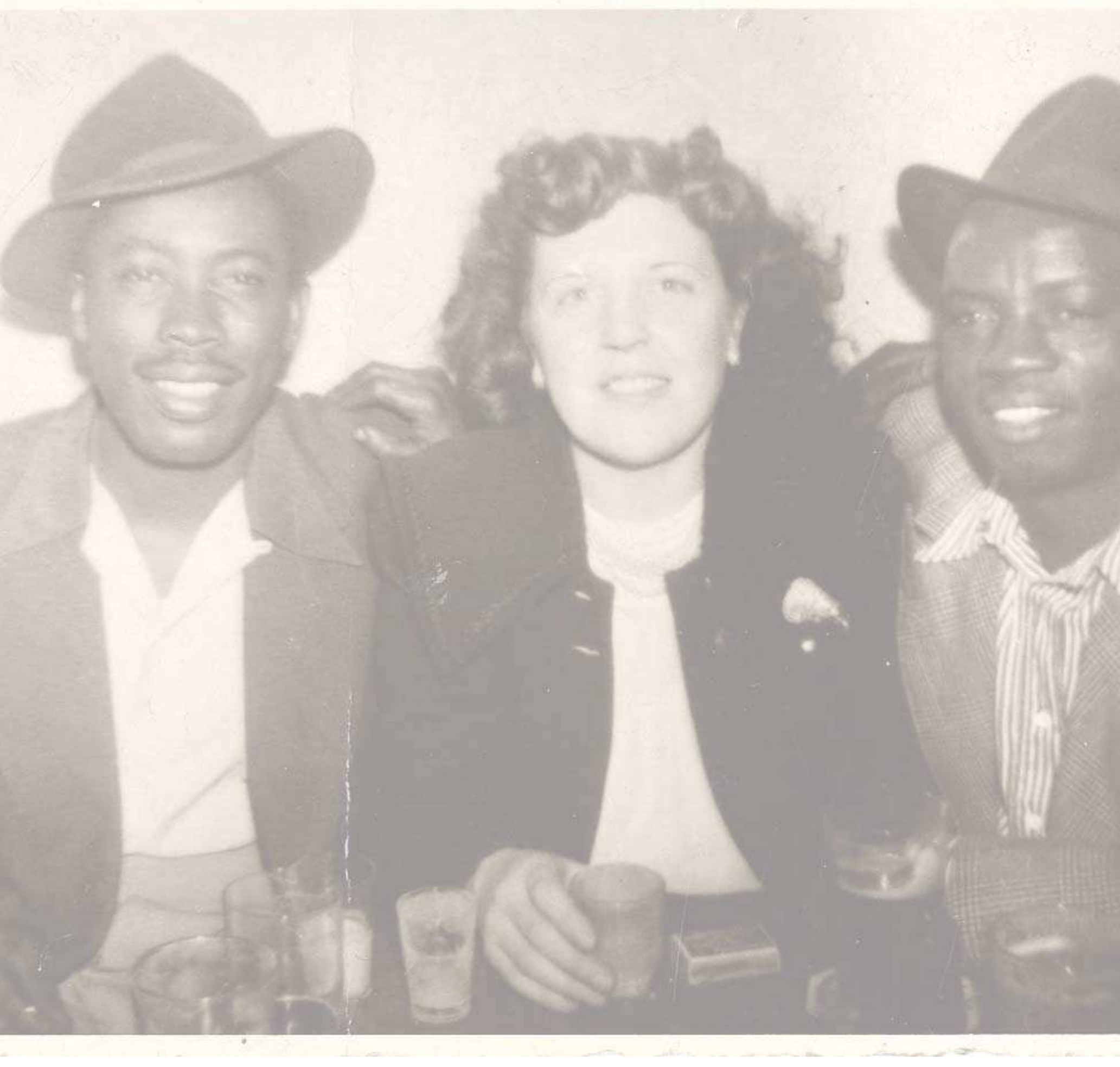




\title{
Ethnicity and Race in a Changing World:
}

\section{A Review Journal \\ Volume 2, Issue 1, 2011}

\author{
Journal Editors:
}

Emma Britain, University of Manchester

Julie Devonald, University of Manchester

Journal Sub-editors:

Ruth Tait, University of Manchester

\section{Associate Editors:}

Professor Emeritus Lou Kushnick, University of Manchester Chris Searle, University of Manchester

The Editorial Board:

Akwasi Assensoh, Professor, Indiana University

Alexander O. Boulton, Professor, Stevenson University

Andrew Pilkington, Professor, University of Northampton and Director of Equality and Diversity Research Group

Aubrey W. Bonnett, Professor, State University of New York

Beverly Bunch-Lyons, Associate Professor, Virginia Tech

Brian Ward, Professor, University of Manchester

C. Richard King, Associate Professor, Washington State University

Catherine Gomes, Dr. RMIT, University Melbourne

Celine-Marie Pascale, Assistant Professor, American University

Dana-ain Davis, Associate Professor, Queens College

David Brown, Dr., University of Manchester

David Brunsma, Associate Professor, University of Missouri

David Embrick, Assistant Professor, Loyola University

Dorothy Aguilera, Assistant Professor, Lewis and Clark College

Fazila Bhimji, Dr., University of Central Lancashire

Glenn Omatsu, Professor, California State University

H. L. T. Quan, Assistant Professor, Arizona Sate University

James Frideres, Professor, University of Calgary and Director of International Indigenous Studies

james Jennings, Professor, Tufts University

Jo Frankham, Dr., CERES, Liverpool John Moore's University 
Kris Clarke, Assistant Professor, California State University

Laura Penketh, Dr., University of Manchester

Lionel Mandy, Professor, California State University

Lisa Maya Knaver, Professor, University of Massachusetts

Lucia Ann McSpadden, Coordinator of International Support and Adjunct Faculty, Pacific School of Religion

Mairela Nunez-Janes, Assistant Professor, University of North Texas

Marta I. Cruz-Janzen, Professor, Florida Atlantic University

Melanie E. Bush, Assistant Professor, Adelphi University

Michele Simms-Burton, Associate Professor, Howard University

Mojúbàolú Olúfúnké Okome, Professor, Brooklyn College, City University of New York

Monica White Ndounou, Assistant Professor, Tufts University

Nuran Savaskan Akdogan, Dr. , TODAIE

Paul Okojie, Dr. , Manchester Metropolitan University

Pedro Caban, Vice Provost for Diversity and Educational Equity, State University New York

Rajinder Dudrah, Dr., University of Manchester

Richard Schur, Associate Professor and Director of Interdisciplinary Studies, Drury University

Roderick D. Bush, Professor, St. John's University

Roland Armando Alum, DeVry University

Samia Latif, Dr., University of Manchester

Silvia Carrasco Pons, Professor, Universitat Autonoma De Barcelona

Teal Rothschild, Associate Professor, Roger Williams University

Thomas Blair, Editor, The Chronicle

Thomas J. Keil, Professor, Arizona State University

Traci P. Baxley, Assistant Professor, Florida Atlantic University

Uvanney Maylor, Dr., London Metropolitan University

Willie J. Harrell, Jr., Associate Professor, Kent State University

Zachary Williams, Assistant Professor, University of Akron 


\section{Contents}

Editorial Statement:

by Associate Editor, Professor Emeritus Louis Kushnick

Essays:

Consuming Slavery, Performing Cuba: ethnography, carnival and 3 black public culture

by Lisa Maya Knaver, University of Massachusetts

South Asian Mobilisation in Two Northern Cities: A Comparison of 28 Manchester and Bradford Asian Youth Movements

by Anandi Ramamurthy, Univesity of Central Lancashire

Comment and Opinion:

Blacks and the 2010 Midterms:

A Preliminary Analysis

by David A. Bositis

William G. Allen in Britain

by Marika Sherwood

\section{Extended Book Review:}

The Transatlantic Indian, 1776-1930 Kate Flint

review by Humaira Saeed 


\section{Editorial Statement}




\section{Essays}

Consuming Slavery, Performing Cuba: ethnography, carnival and black public culture

by Professor Lisa Maya Knaver, University of Massachusetts

South Asian Mobilisation in Two Northern Cities: A Comparison of Manchester and Bradford Asian Youth Movements by Dr. Anandi Ramamurthy, Univesity of Central Lancashire

Peer Reviews for this issue were provided by: 


\title{
Consuming Slavery, Performing Cuba: ethnography, carnival and black public culture ${ }^{1}$
}

\author{
Professor Lisa Maya Knaver, University of Massachusetts
}

Anthropologist Michel-Ralph Trujillo notes that "any historical narrative is a particular bundle of silences." ${ }^{2}$ This article explores the silences and gaps around slavery and its legacy in the historical narratives that animate Cuba's heritage landscape and inform cultural performances. I argue that the ways slavery is, and, more tellingly, is not represented at heritage sites, and in state-sponsored cultural performances provides a lens for examining a larger ambivalence concerning race in the Cuban national imaginary. ${ }^{3}$ Rather than focusing on slavery as a mode of institutionalized violence, a set of social relations, and ideological structures, Cuban heritage narratives, cultural productions and visual representations highlight cultural contributions made by peoples of African descent to Cuban national identity. ${ }^{4}$ While slave resistance is sometimes mentioned or enacted, racism and race are usually relegated to a fairly distant past. Cuban narratives thus downplay the racialized history of the nation and instead promote an inclusive, post-racial nationalism. It is as though enslaved people left an imprint, while the institutions, social relations and ideologies responsible for their enslavement vanished without a trace.

In particular, I want to interrogate the intricate and dialectical interplay between two modes of cultural presentation that Cuban cultural institutions deploy in their treatment of black culture that I call "the ethnographic" and "the carnivalistic". "The ethnographic" is a form of cultural presentation that purports to be historically and cultural accurate or authentic (itself a problematic concept), often drawing upon ethnographic research. "The carnivalistic" emphasizes spectacle, staging, and theatricalization. These are not, I argue, mutually exclusive or separate endeavors, cleanly distinguished in time, space, or sponsorship, but can be competing or even complementary impulses that inform a single museum display or music and dance performance. Nor are they the exclusive province of state cultural functionaries, although the most of the icons and performances I discuss are produced and circulated with at least the tacit permission of the state, if not direct state sponsorship. Performers, vendors and ordinary citizens, in Cuba as elsewhere, can adopt these modes of selfpresentation for strategic or other reasons.

My analysis is based on a close reading of two sets of cultural productions. ${ }^{5}$ First, I look at the circulation and consumption of a series of inanimate objects representing Black people and Black culture in Cuba - principally dolls, small statues and carvings found at tourist sites and throughout the heritage landscape - and also how these are animated by Cubans who perform these or similar identities, particularly noting which characters are minimized or silenced in the tourist industry. I also explore how similar icons are consumed and used in everyday settings. I then examine more structured cultural performances that actively encourage the enactment or representation of accepted slave experiences, focusing on an annual re-enactment of a colonial-era "black carnival" parade. ${ }^{6}$

The theatricalized spectacles seem, at first glance, to occupy a different register than the more ethnographically informed representations in museums or discussions of black culture in scholarly publications. Yet, I argue, that they are part of a continuum. Each one references, in distinct ways, a lengthy history of popular and high art renditions, folkloricized performances and ethnographic displays of black-identified cultural forms in Cuba. Since most of these performances and sites come under the aegis of state cultural institutions, they can be seen as efforts to governmentalize and "contain" Afrocuban religion and black public culture through preservation and re-enactment.7 I suggest that the meanings of these productions are not static, nor are they determined solely by 
cultural and heritage officials. Instead, I view this terrain as a zone of friction, in which the (mostly black) producers of these cultural performances, audiences as well as everyday Cuban citizens, actively complicate and contest the encoded meanings and create counter-narratives, and use them to advance their own agendas. ${ }^{8}$

To contextualize my discussion of the interplay between race and national identity in present-day Cuba, I start with a brief sketch of the emergence of the tourist economy, including how both race and the commoditization of culture have been shaped by larger dynamics. While Cuba has its own particular constellation of ideologies and debates about racial and national identities, the ironies and frictions I discuss are not unique to the island. Nor is the commoditization of culture, usually combining ethnographic and carnivalistic approaches, a recent development. However, it has become more ubiquitous than ever, and is a hallmark of neoliberalized development strategies and tourist economies in many parts of the world. ${ }^{9}$

\section{Old and new cultural economies of race in Cuba}

Racial ambivalence came into sharp relief immediately following the collapse of the Soviet Union, a period of severe economic, social and political crisis in Cuba that the authorities euphemistically labeled "the special period in a time of peace". In the wake of the loss of Soviet economic supports, the Cuban government shifted its economic policies to promote tourism as a source of hard currency to prevent economic collapse and support social spending. While Cuba and its foreign investors have developed numerous "sun and sand" resorts, there have also been efforts to promote cultural (and also medical) tourism. Consequently, the "heritage industry" has exploded as a result of foreign and domestic investment in heritage projects. These include museums, the reconstruction of Habana Vieja (Old Havana) under the aegis of UNESCO "patrimony of humanity" designation, and Cuba's component of the transnational "Slave Routes" project. ${ }^{10}$

By the start of the twenty-first century, tourism revenues accounted for over a third of Cuba's hard currency income. ${ }^{11}$ Although tourism fell off after September 11, 2001, it remains one of the largest sources of hard currency and is a pillar of Cuba's economy. ${ }^{12}$ At the same time, the Cuban government implemented several other market-oriented initiatives, such as re-establishing farmers' markets which allowed farmers to directly sell part of their yield to consumers, ${ }^{13}$ and opened the door for certain kinds of self-employment and independently-owned small businesses. ${ }^{14}$

In 1993, the state legalized the possession of U.S. dollars and allowed ordinary citizens to patronize the hard-currency stores which sold goods not available via the libreta (ration-book); these were formerly limited to diplomats, other foreign visitors and party officials. The government also opened hundreds more hard-currency stores, not only in tourist zones but in ordinary residential neighborhoods in Havana and other cities. The dollarization and marketization of the economy was at the same time an effort to legalize but also regulate and contain the vast informal sector that had sprung up as thousands of Cubans began to inventar (literally, to invent, but often meaning "to hustle"), so that they could resolver (resolve) their economic needs in the wake of the economic collapse. ${ }^{15}$

This growing marketization, combined with increased numbers of both foreign and diasporic tourists, spurred consumption, consumerism, and the commercialization of daily life. ${ }^{16}$ Some of Havana's prerevolutionary shopping streets that had fallen into disuse or disrepair were refurbished and turned back into commercial zones. In residential neighborhoods like Cayo Hueso in Centro Habana (Central Havana), streetscapes featured a mixture of small enterprises, Cuban peso stores and hard-currency stores. ${ }^{17}$ By contrast, streets like Calle Obispo in the tourist zone of Habana Vieja are lined with many upscale boutiques and eateries. 1997 saw the opening of Havana's first multi-story mall - and the first shopping center of any sort to be located in an historically "inner city" neighborhood -- the Plaza Carlos III. During my years of field visits to Centro Habana, the mall was usually crowded, with people 
congregating in the downstairs food court and the sidewalk outside the main entrance. Cubans sought not only daily necessities like soap and cooking oil that had been in short supply during the harshest years of the special period but brand-name clothing, electronics and other consumer goods sported by tourists and available at relatively high prices in state-owned hard currency stores (or in the still-vibrant informal economy). ${ }^{18}$ Going to la shopping - Cuban slang for a hard-currency store -- became a daily activity and, for many, a form of entertainment. ${ }^{19}$

As hotels, resorts, hard-currency stores and small enterprises have mushroomed, Cuban culture, and especially Black-identified culture, has become increasingly commoditized and packaged for touristic consumption. And herein lie some of the most potent ironies. Recent studies, most notably by Cuba's Centro de Antropología (Anthropology Center), have substantiated what many scholars and others argued earlier based upon anecdotal evidence: that the marketization of Cuba, its rearticulation into the global economy through tourism, assorted joint ventures and remittances, have helped produce new forms of stratification and possibly a nascent class formation, whose contours are influenced by race, gender and geography. Blacks have a harder time finding a foothold in some sectors of what scholars are labeling the "emergent economy" (front-desk jobs in tourism and joint enterprises). Instead, they are hired for more menial jobs in tourism such as chambermaid, waiters, parking attendants, doormen and bellhops. ${ }^{20}$ Blacks receive less remittance money from relatives in the diaspora to finance self-owned businesses, and therefore seek opportunity in the informal sector. Black men are over-represented in the ranks of street hustlers, or jineteros, who frequent tourist locales. Rehearsing racialized (and gendered) tropes that date back over a century, black women's bodies (and to a degree, black men's bodies) are highly desirable commodities for foreign tourists seeking sexual adventure. ${ }^{21}$ Black male bodies are still construed as dangerous and disruptive in public space (and commoditized private spaces such as resorts), and black men are subject to disproportionate surveillance by police and hotel and resort staff.

That race is being discussed at all - the Centro de Antropología's research was covered in Granma, the official Communist Party daily newspaper -- represents a shift. However, official discourse largely describes racism as a matter of prejudiced views held by individuals and an unfortunate legacy of the past. It thus sidesteps institutional or structural factors -- such as the historical ambivalence concerning whether blacks could ever be good Cuban citizens, and the post-revolutionary silencing of discussions of race. ${ }^{22}$

At the same time blackness has become a desirable commodity in other arenas of the tourist economy. ${ }^{23}$ Cultural practices marked as "black" - folkloric music, dance and "religions of African origin" - which the authorities formerly frowned upon and discouraged, or sought to convert into vehicles for the promotion of socialist values-- have been turned into valuable cultural currency. Foreign and Cuban tour operators offer opportunities to study "traditional" Afrocuban music and dance and observe religious ceremonies. ${ }^{24}$ Some enterprising santeros and santeras (santeria priests and priestesses) and other Afrocuban religious specialists have been able to register their homes as state-recognized cultural centers. ${ }^{25}$ Many performers, artisans, and religious practitioners have thus been able to parlay their expertise (real or ascribed) in black culture into a means of supporting themselves and their families.

As I detail below, performances, museum displays and tourist souvenirs reinforce deeply embedded racialized and gendered images. For example, Havana's legendary Tropicana nightclub, which dates back to the late 1930 s when Cuba was promoted as a tropical paradise for thrill-seeking foreigners, still presents nightly cabaret performances featuring a chorus line of statuesque and scantily clad mulata (light-skinned black women) dancers. ${ }^{26}$ The expansion of the tourist industry led to the recent opening of two additional branches of the Tropicana in Cuba's eastern city of Santiago and near the beach resort of Varadero. The music and dance revues at the Tropicana and other cabarets usually 
offer highly stylized and sometimes quite fanciful versions of black-identified "folkloric" genres like rumba and Afrocuban religious music and dance ${ }_{1}{ }^{27}$ along with guest appearances by more "traditional" performers of Afrocuban folkloric music. Meanwhile, there has been a small explosion of open-air and indoor venues for more "authentic" Afrocuban folkloric music (along with the emergence of several new folkloric ensembles seeking performance opportunities).

The upbeat, celebratory tone of most of these performances, and the emphasis on festive ethnicity, the folkloristic and the performative fit well with the government's promotion of a raceless or racially inclusive nationalism..$^{28}$ Emcees at cultural performances frequently recite José Martís aphorism, "In Cuba there will never be a race war ... Cuban is more than white, more than mulatto, more than black..."29 The hit song "La Vida es Un Carnaval", popularized on the island by Isaac Delgado, could well serve as a musical version of one of the carnivalistic master tropes deployed by the state tourist industry - a sun-drenched island paradise where people sing their cares away (the song's chorus exhorts the listener, "Ay, there's no need to cry, life is a carnival, and singing will take away your cares." $)^{30}$

The performativity of these varied registers of cultural production - the breathing actors alongside the static icons -must be interpreted within the context of Cuba's heritage landscape, which has been shaped by the intersecting, sometimes complementary and sometimes competing desires, and projects, of global capital, the Cuban state, cultural promoters, cultural producers and performers, everyday Cuban citizens, and tourists. In this contact zone, varied imaginaries and identities are constructed, narrated, negotiated and contested. As Daina Harvey notes in her discussion of black heritage sites in New Jersey, spaces are experienced differently by tourists and residents. ${ }^{31}$ The promotion of these images, objects and performances by both public and private actors in the tourist and heritage industries speaks volumes about the racialized and gendered cultural economy of contemporary Cuba.

The performative spectacles, both the ethnographic reconstructions and the everyday commoditized enactments, are set within a heritage landscape that avoids mention of racial disharmony, past or present, or, largely, of slavery itself except safely enshrined inside museums, and there usually only obliquely. The idealized quaintness of the restoration of Habana Vieja is itself a kind of whiteface minstrelsy: it evokes the glory of the Spanish colonial past while never mentioning colonialism. Urban spaces are palimpsests, but historic restorations or reconstructions are always selective in the slices or fragments of the past they chose to recover or recreate; they inevitably omit or suppress certain narratives while reframing and emphasizing others. In selecting one particular historic freezeframe, even the most faithful reproduction (involving legions of archaeologists and architectural historians) ignores everything that preceded or followed it. ${ }^{32}$ History often becomes a vehicle to promote consumption, particularly by foreign tourists. Further, planning decisions are usually made by developers, bureaucrats and experts; present-day residents of the surrounding area are either left out or given limited voice. 33

The Centro Histórico (historic center) of Habana Vieja was restored and reconstructed under the auspices the Office of the City Historian of Havana (referred to herein by its Spanish acronym OHCH). $\mathrm{OHCH}$ is a unique semi-autonomous governmental agency that has been charged with supervising the reconstruction of Old Havana and promoting tourist development. ${ }^{34}$ The Cuban government has given the $\mathrm{OHCH}$ extraordinary powers to raise revenues for reconstruction through tour agencies, commercial ventures, and admission fees to museums, pseudo-museums and historic sites, and to establish joint ventures with foreign companies and governments. 35 The governments of Spain and the Canary Islands (and also Spanish banks) underwrote much of the reconstruction of Habana Vieja, sparking quips that this amounted to a reconquista or reconquest by the former colonial power, a century after independence. 
There is little in the historic center that directly signals the presence of enslaved (and some free) Africans who undoubtedly contributed much of the labor that built the houses, fountains, churches, and laid the paving stones. A recent mural depicting Havana "society" of the nineteenth century includes two or three black faces (see figure 1). More alarmingly, the whitewashed facades of the majestic Plaza Vieja are narrated by a billboard with a blandly nationalistic quote from José Antonio Saco, the chief promoter of the colonial-era policy of blanqueamiento -- whitening Cuba's population through increased Spanish immigration. The specter of Haiti as the world's first free black republic haunted nineteenth century Cuba, and the explosion of the black population produced by Cuba's sugar boom stoked racial fears even within the anti-colonialist movement. Saco and many others now heralded as great Cuban nationalists did not want a Cuba libre (free Cuba) with a black majority. The silencing of this narrative produces a weird kind of kaleidescoping; by ignoring or deleting any mention of these past efforts to literally whitewash Cuba's population, the authors and architects of these and other historic sites also whitewash the racially troubled present, and deflect any suggestion

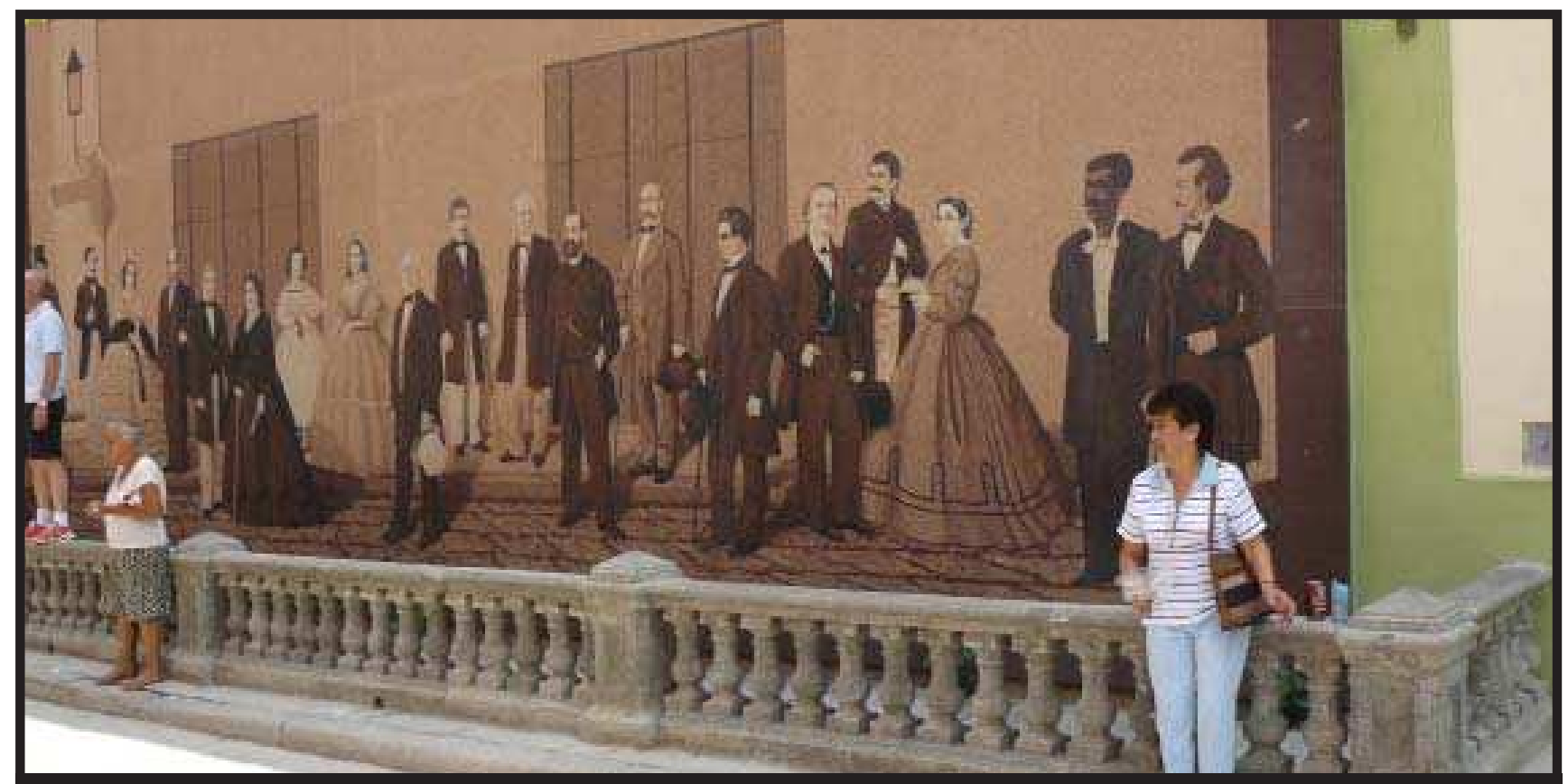

Figure 1: A recently-installed mural depicting nineteenth century Havana society, on a busy pedestrian street in the Centro Histórico

that race continues to be an issue in Cuba. There is nothing in the official signage to unsettle the claim that Cuba is a raceless society.

The absence of direct reference to slavery in Havana's historic (and touristic) center contrasts with the hulking socialist realism of the Monument to Carlota's Rebellion, commemorating a nineteenth century slave uprising (see Figure 2). This imposing sculpture, however, is located in an isolated (although strikingly beautiful) corner of Matanzas province. When I visited in June 2007, accompanied by an official of the provincial Department of Patrimony, we were the only visitors. Cuba participated in the initial UNESCO-sponsored discussions that led to the Slave Routes (La Ruta del Esclavo) initiative, and has identified and inventoried numerous sites of historic significance -ruins of plantations, sugar mills, slave barracks or barracones, slave cemeteries, many of which are located well outside of Havana, in what anthropologist Anna Tsing calls "out of the way places"..$^{6}$ The Museum of the Slave Route is housed in the restored Castillo de San Severino, on the outskirts of the city of Matanzas, and is not easily accessible except by automobile or tour bus. ${ }^{37}$ Matanzas boasts 
many beautiful colonial-era buildings and is recognized as a center of Afrocuban religion and music, and it is not far from the resort town of Varadero, but many tourists head straight for the beaches. ${ }^{38}$

\section{Objectifying (and selling) blackness}

With this contextual sketch, I now turn to the objects and performances. My analysis begins with the nearly ubiquitous figure of a black female doll I purchased at a tourist shop in Habana Vieja (see figure 4). These dolls, which come in varied sizes, are made of black cloth and dressed in colonial-era dresses, often covered with an apron. Characteristically, they wear matching headscarves and sometimes golden-colored hoop earrings. The dolls are available from street vendors and at souvenir shops throughout the Centro Histórico, and also at handicraft markets and tourist shops across the island. Similar dolls are sold at tourist sites throughout the Caribbean; when I presented a preliminary version of this article at a conference in Barbados, and held up my Cuban doll, several people asked me if I had purchased the doll in Barbados.

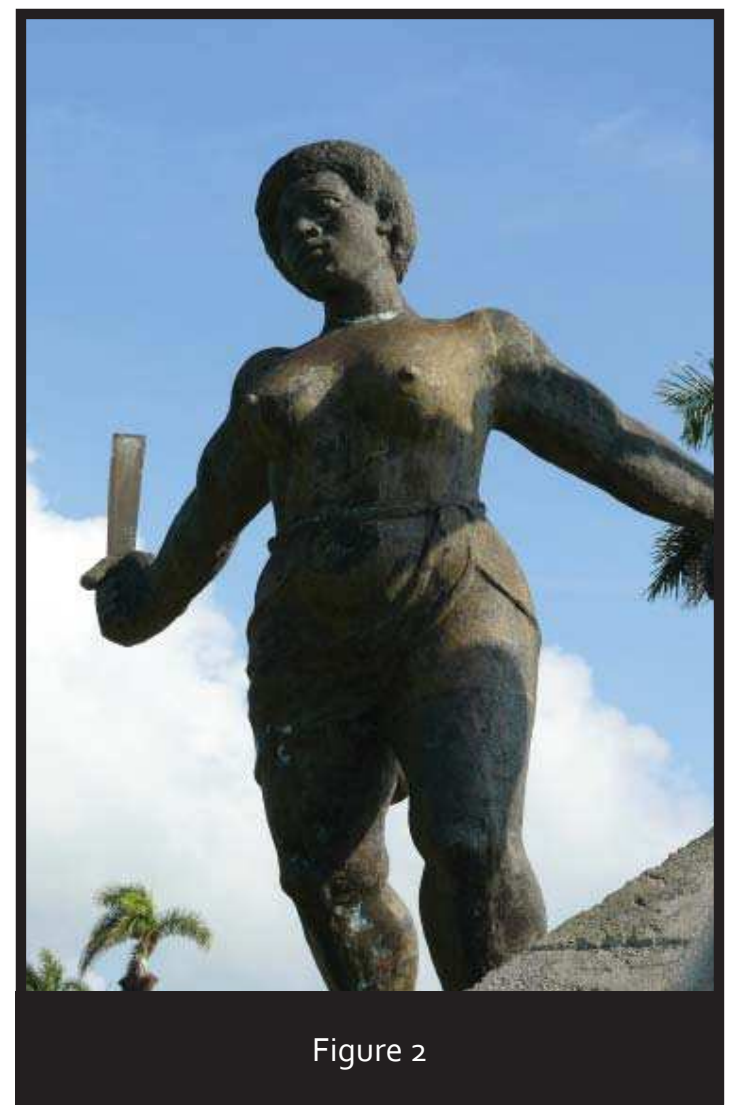

Other images of blackness are on display and for sale in tourist areas and museums throughout the island. Carved wooden statues, painted ceramic figurines and paintings rehearse other racialized and gendered tropes that are part of both the national and touristic imaginaries: the smiling and ever-available mulata, usually clad in a skin-tight dress emphasizing her ample hips and bosom, which is sometimes barely contained by the dress, and jovial black men rolling cigars, playing drums or holding serving trays. Some of these figures are relatively realistic, but others are gross caricatures, with bulbous lips, or extravagantly exaggerated breasts and bottoms.

Silenced are the stories of the origins of these figures: their post-colonial minstrelsy has roots in the exoticized caricatures or more romanticized representations of the colonial imaginary: the blackface theater, negrista literature and costumbrista visual arts that flourished in nineteenth century Havana. ${ }^{39}$ What makes these images problematic is not solely the nature of the tropes themselves, but also the contexts in which they are disseminated. All of the venues where these icons are sold are either licensed or run by state enterprises. Here images of smiling complacency, servility and sexual availability - the enslaved or subordinate status often implied rather than articulated -- are juxtaposed with equally exoticized but more generic "African" style carvings that began to appear in Cuba's tourist zones in the 1990s, and other more genuinely national icons such as hand-rolled cigars, bottles of rum and the superficially more rebellious visage of Che Guevara that is endlessly reproduced on t-shirts, caps or newspapers..$^{40}$

Vendors, of course, offer what they think the tourists want. But very little takes place in the Centro Histórico without the permission or imprimatur of the Office of the City Historian of Havana. All of the vendors operating in the historic district, whether in stores or stands in the artisans' fair, must be licensed by the $\mathrm{OHCH}$, and the $\mathrm{OHCH}$ 's power to award (or deny) licenses is a source of contention for local residents who want to operate small businesses.

These kinds of carnivalistic figurines and dolls are sold not only in stores and fairs that are clearly 
commercial and geared towards tourists, but also at gift shops in ostensibly more high-minded museums. Figure 3 shows a shelf in the gift shop at the Museo Histórico de Guanabacoa (the Historical Museum of Guanabacoa), a municipal museum with a more serious ethnographic and historical mission, and one that is internationally recognized for its carefully designed and "authentic" dioramic displays of Cuba's religions of African origin..$^{41}$ Similar figures are sold at other equally high-minded museums. ${ }^{42}$

The high-art and commercial originals of these archetypes are on display at the newly refurbished Museum of Fine Arts in Habana Vieja. A small room tucked away off the main exhibition space contains an exhibit devoted entirely to the nineteenth century tobacco marquillas (cigar box labels), lavishly illustrated by some of the most noted artists of the day, often with scenes of plantation and black urban life; they are a rich source of information about the highly gendered racial economy of colonial Cuba. ${ }^{43}$ In addition, there are several paintings by French artist Victor Landaluze, who was celebrated for his colorful and "authentic" depictions of everyday scenes of black urban life in Cuba. Dandified black men in brightly colored clothing swagger and flirt with equally resplendent women. Completely absent is any curatorial or critical commentary about costumbrismo, the colonial gaze, or slavery; indeed few works are even labeled. ${ }^{44}$

These figures are further complicated by the existence of their real-life counterparts on the streets outside. The sweeping plazas of Habana Vieja, many now restored or refashioned a nearly-pristine colonial-era veneer, are also stages for costumed men and women (mostly women) who seem to have stepped out of the costumbrista canvases inside the museum. In front of Havana's massive seventeenth century cathedral a heavy-set, dark skinned, middle aged woman, sits at a small table and offers spiritual advice and readings. She is dressed in voluminous white skirts and a headscarf, and wears numerous beaded necklaces; for many Cubans and some foreign visitors familiar with Afrocuban religions, these are easily legible symbols of religious affiliation. ${ }^{45}$ She frequently puffs on a fat cigar (which doubles as a national and religious icon) and can be found here year round. There are a few other similarly outfitted women in different sites throughout the Centro Histórico, although none seem quite as emplaced and authoritative as she.

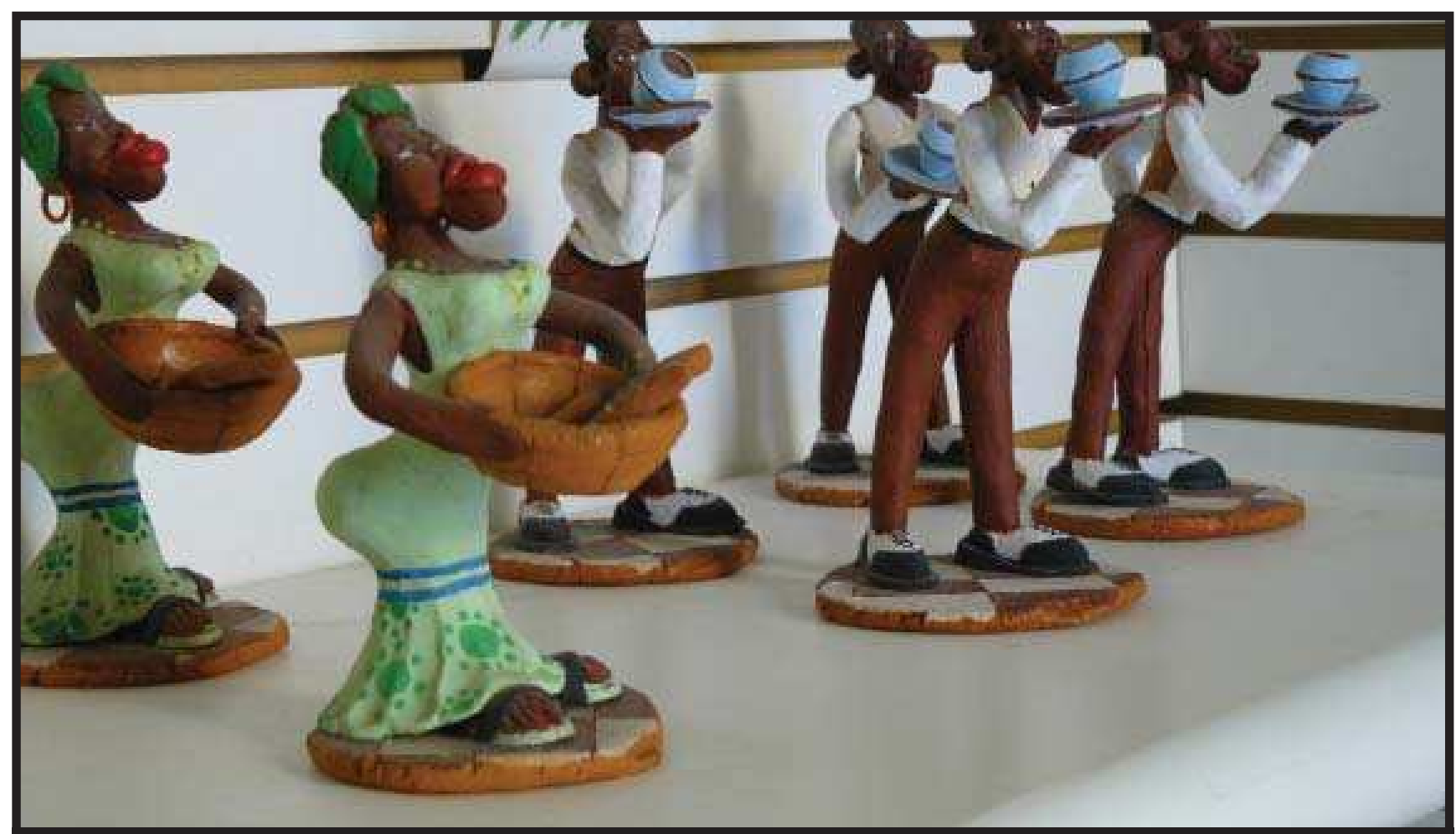

Figure 3: Gift shop, Museo Historico de Guanabacoa 
Occupying a slightly different niche in the tourist imaginary are several younger, more nubile women enacting the roles of colonial-era vendors, dressed in colorful flowing gowns, bearing baskets of flowers or fruits and bright smiles. Where the older women are stationary, planted in their spots, the younger women are mobile, approaching tourists as they are disgorged from buses or simply wandering on foot through the historic district, offering to pose for photographs for a small fee. The somewhat more abject or rebellious figures of the male slaves, usually in small ceramic figures or wooden carvings, do not have real-life counterparts outside of staged folkloric performances, many of which include a choreographed set piece of a slave revolt, but the carved and painted waiters and musicians come to life in tourist spots across the country. Hundreds of professional musicians -a majority of whom, for historic reasons, are black men, all of whom are state employees - regale patrons at indoor and open-air bars, cafes and restaurants, while other men (and some women) many of whom are black -- prepare and serve the food and drink that the patrons consume..$^{46}$

While a full analysis of each of these iconic images and performances would be an intriguing and useful exercise, it is beyond the scope of this article. However, it is worth delving into one common figure, the dark-skinned female cloth doll who looks like a Cuban counterpart to the "Aunt Jemima" or "mammy" dolls in the U.S., and who has a complicated legacy in Cuban popular culture. ${ }^{47}$ The stout, dark-skinned woman wearing a head wrap was a popular image in nineteenth century marquillas, which are a rich source for studying racial and gender ideologies in colonial Cuba. Well-known fine artists such as Victor Landaluze created designs for many of the labels, and they blur the boundaries between high art and commercial culture. Although Jill Lane argues that blackface minstrelsy was sometimes used for anti-colonial ends, the visual narratives in the marquillas often played out racialized fears about Cuba's future and specifically the place of blacks. ${ }^{48}$ The dark-skinned woman or negra in the tobacco marquillas is often the mother of the light-skinned mulata, who is depicted as alluring and highly desirable. She reflects a national racial/gender ideal. While the negra is thus implicitly or overtly the sexual partner of a white man, she is never his wife, and the visual portrayal of their relationship sometimes suggests rape or seduction on the one hand, or a commercial transaction on the other. While the dark-skinned woman is thus shown as a sexual being (unlike some of the more desexualized portrayals of dark-skinned black women in U.S. popular cultural iconography), she is clearly less desirable than, and inferior to, her lighter-skinned offspring. ${ }^{49}$

However, turning an ethnographic lens on how the dolls in circulation today are consumed, we find that not all are purchased by tourists. I saw numerous dark-skinned female dolls with head wraps -- sometimes older, visibly careworn, and with less exaggerated features -- in the homes of Cuban friends. In some cases they were simply decorative items, placed on crocheted doilies on a sofa or shelf, but often they were part of an altar for one of the African-origin religions. In these contexts a doll may personify a person's spirit guide in espiritismo (spiritism), one of the orishas in la regla de ocha or santeria (the deities Yemayá and Oyá are both represented as dark-skinned black women), or a similarly powerful female figure in palo monte. The dolls serve as entry points for the divine healing energies of these religious practices, and are thus sacred items. When I photographed my friend Caridad Moré, she chose to sit in front of her altar with one of her dolls in her arms (see Figure 5).

As material cultural artifacts associated with African-origin religions, older dolls which are no longer used for religious purposes have passed into the collections of museums with ethnographic displays devoted to these religions such as the Historical Museum of Guanabacoa or Casa de Africa, becoming "objects of ethnography." $5^{\circ}$ Their real-life counterparts are not limited to the self-exoticizing fortune tellers of Habana Vieja, but can be found in religious ceremonies, markets and households across the island.

Aside from a few scholars and artists, few Cubans (including black Cubans) seemed troubled by these images. They have become naturalized as part of the island's visual iconography and abound in local 
domestic material culture. An African American female scholar reported questioning some vendors in old Havana (while trying to conceal her own troubled response to the images). She noted that they seemed genuinely proud of the items, and thought them beautiful and important representations of authentic Cubanness with no trace of irony. ${ }^{51}$

Alexis Esquivel, a Cuban artist whose work critically interrogates race, has produced a series of paintings and performances based on these dolls. He noted that many Cuban viewers do not "get" the critical component of his work but instead view the paintings as high-end, slightly abstracted versions of the kitschy popular culture items. To underscore how much these stereotyped images have become normalized and taken for granted, he added that since he purchases dolls as models for paintings or to include in performances, once he has finished using the dolls, his mother asks for them afterwards to decorate her apartment. ${ }^{52}$

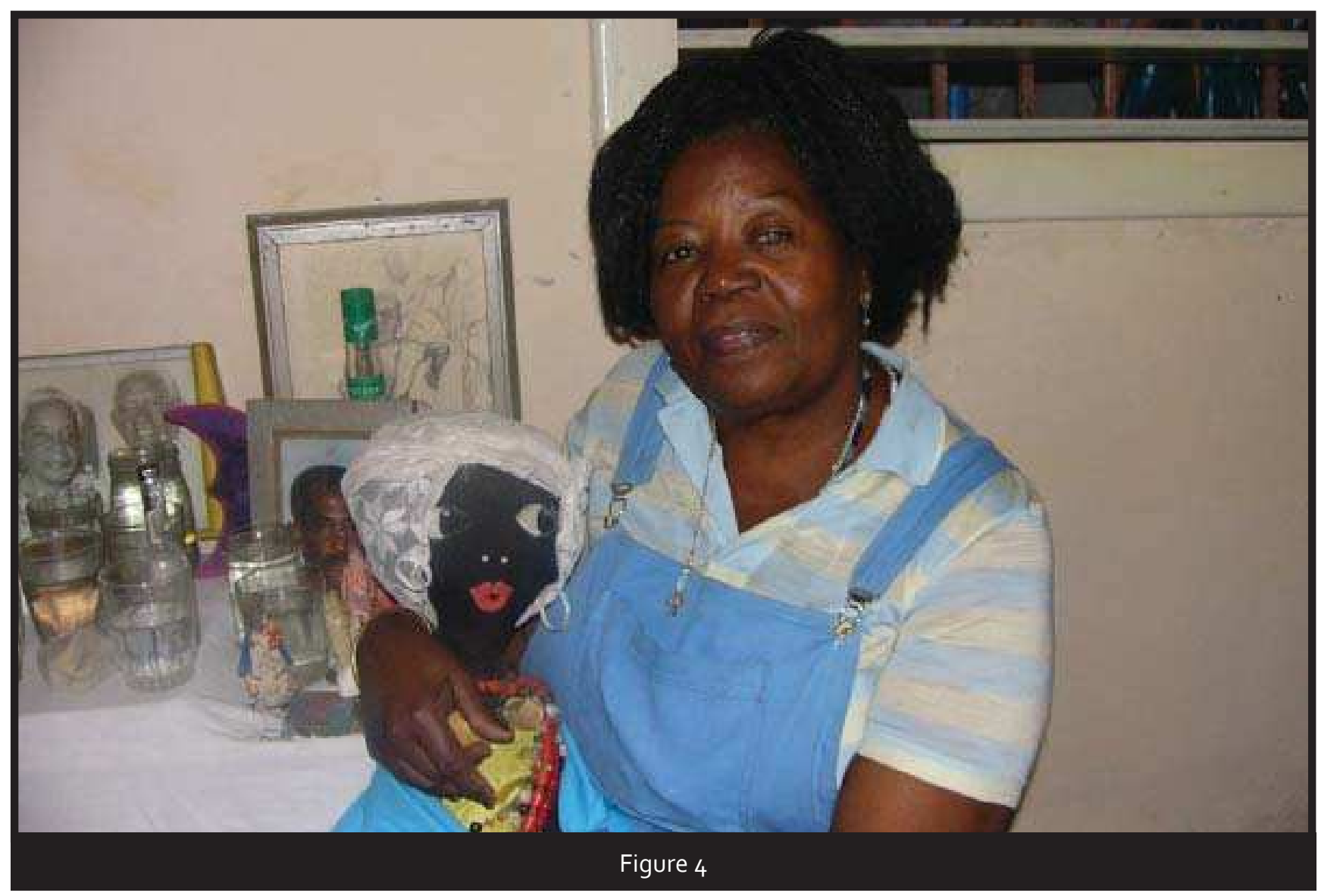

\section{Performing the nation}

I now turn to a fully theatricalized performance drawing upon Afrocuban religious music and imagery. For the last decade or so, on January 6 at around mid-day, a festive, noisy and colorful parade has snaked its way around the streets of Habana Vieja. Led by a regally-attired couple, the King and Queen of the parade (see figure 5), the event labeled "La Salida de los Cabildos" is sponsored by Casa de Africa (Africa House), a museum that houses a substantial part of the collection of Fernando Ortíz, often heralded in scholarly and bureaucratic discourse as "the third discoverer of Cuba" for his efforts to document and legitimate African-derived religious and musical practices as authentic and essential components of the ajiaco or "stew" of Cuban national cultural identity. ${ }^{33}$ And the date of this procession - January 6 - was not randomly chosen. The procession purports to be a recreation of the Día de los Reyes (literally, "day of the kings" but usually translated into English as Three Kings" 
Day), the Feast of the Epiphany on the Catholic calendar. During Spanish rule this was the only day when Havana's substantial population of Africans and their descendants - both free and enslaved - were permitted to "go out" (salir) onto the city streets with drums and costumes and "perform themselves".

The exact itinerary of the recreated parade varies from year to year, as the parade organizers must factor in the state of reconstruction and preservation efforts, and both performers and the ambulatory audience must work their way around scaffolding, wooden beams and potholes. However, unlike the quotidian and more informal cultural performances described above, the modern-day parade was designed as a somewhat more high-minded endeavor and attempts to provide an "authentic" representation of the African contributions to Cuban culture. At each of the central plazas, the procession stops and performers present a short set piece of music and dance from one of the sacred Afrocuban traditions: the regla de ocha or santeria (derived from the Yoruba-speaking peoples of what is now Nigeria), Palo Monte (based on Bantu or Congo cultures of West-Central Africa), and the masked dancers, called iremes or diablitos ("little devils") of the all-male Abakuá secret society (based upon similar sodalities in the Calabar region of what is now Nigeria). However, for the passing tourist, there is little to distinguish this once-a-year parade from the everyday, more overtly commoditized spectacles that I have just described; there is no emcee or explanatory brochure.

The event of which it is a somewhat aestheticized and fanciful reinterpretation, the Díia de los Reyes, is part of the complex and doubly bifurcated carnival tradition in Cuba. ${ }^{54}$ The modern-day event, the Salida de los Cabildos, takes its name from the one form of sociocultural organization that blacks were permitted during the tiempo de la colonia (colonial times) - the mutual aid societies called cabildos. The cabildos, originally established under the auspices of the Catholic Church, were relatively autonomous and established their own internal social organization. They were often able to purchase buildings and land (as well as the freedom of their enslaved members), and since the authorities often left them alone, they provided a fertile ground for the preservation or recreation of African religious and cultural practices. ${ }^{55}$

During the colonial period, Havana, like many other cities in the circumCaribbean, had black and white carnivals that were separated spatially and temporally. The Creole (island-born) elite held a pre-Lenten Carnival rooted in medieval European

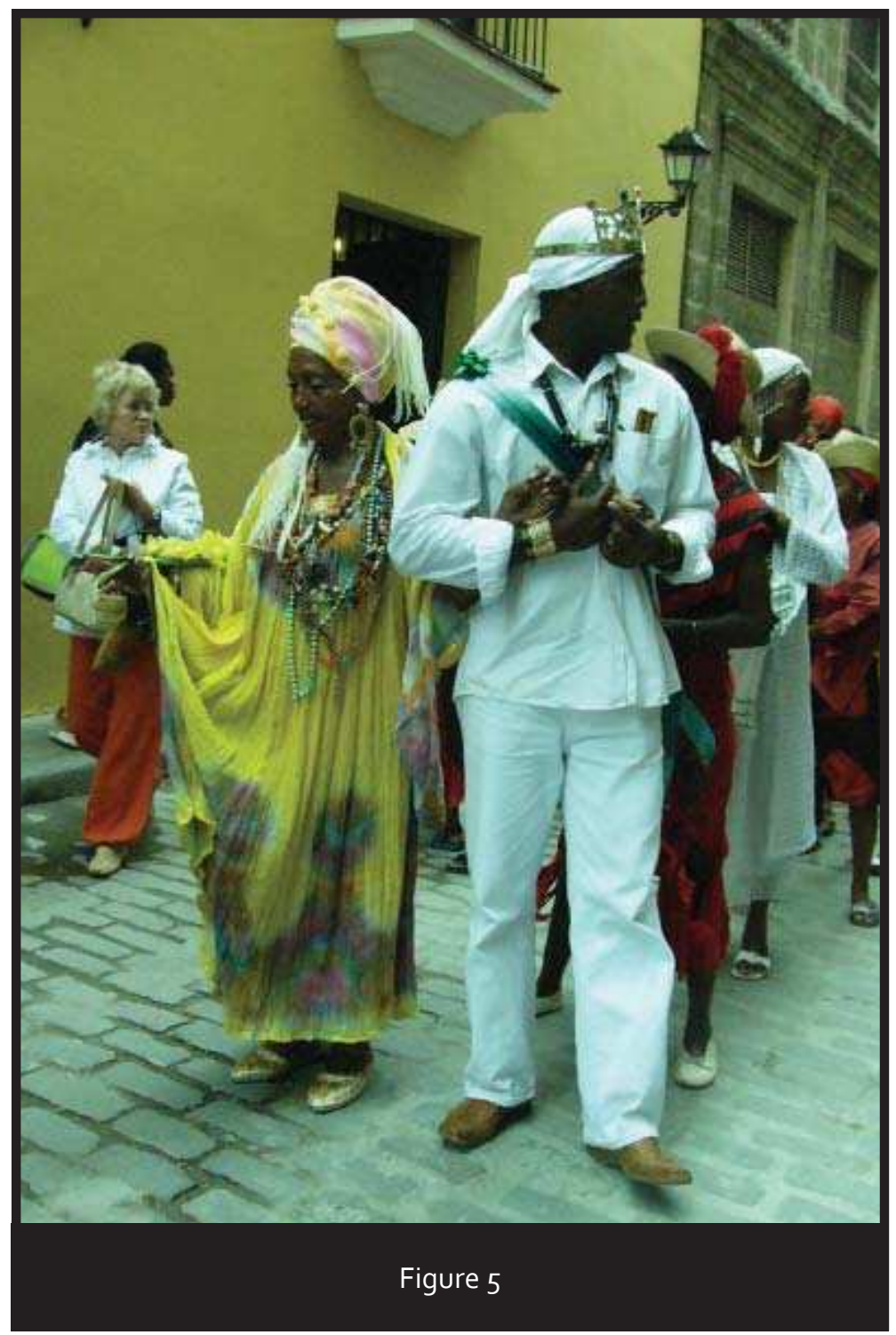


traditions. Blacks were only allowed to participate in the white carnival in a limited way but not to organize their own comparsas (street bands).

However, Blacks were allowed to parade in the streets with costumes and comparsas on January 6. While blacks reveled in the streets and plazas, whites watched from the safety of their balconies. The streets of the old city, on that day, were a black space. The closest we have to an ethnographic or historical record of these events are a few verbal and visual sketches, mostly from European visitors, and some police records. According to these accounts, the Día de los Reyes was exuberant, festive and noisy.

The Día de los Reyes, like other forms of black cultural production, especially those involving drums and disorder (real or imagined), was subject to disciplining and repression by the colonial authorities. During Cuba's protracted wars of independence (starting in the 186os), colonial officials and the elite feared that blacks might join the anti-colonial struggle or revolt on their own. The authorities closed down many cabildos, and the Día de los Reyes was restricted and eventually banned in the mid$18805 .{ }^{57}$ According to older Habaneros (Havana residents), people continued to celebrate the Día de los Reyes but in smaller, more private ways..$^{8}$

Most of the actual cabildos, the mutual aid societies that historically served enslaved and free blacks, no longer exist today. Some of those that were closed by colonial authorities were later allowed to reopen. However, black culture again became a flashpoint for racial fears after Cuban independence in the early twentieth century. Many blacks had fought in the liberation army as they saw independence as the way to end slavery, and perhaps achieve Marti's vision of a raceless society. However, their hopes for full inclusion were not realized, and some black veterans formed the Partido Independiente de Color (the Independent Party of Color) in 1908. The authorities reacted by outlawing parties based on race or class. The PIC led demonstrations in Oriente Province that the press immediately labeled a race war or an armed revolt. The government response was bloody and brutal: several thousand blacks (not all of them supporters of the PIC) were killed by soldiers dispatched to "put down" the revolt. Newspapers carried wild reports about blacks murdering and raping whites, and civilian militias killed dozens of people throughout the island who had nothing to do with the protests. ${ }^{59}$

In this climate, the modernizing elite launched efforts to wipe out what they saw as backward, savage and atavistic elements of Cuban culture. A wave of "witchcraft" scares swept the country and Afrocuban religious practitioners were harassed and arrested. Several abductions and murders of white children were attributed to black "sorcerers". The police harassed and sometimes arrested Afrocuban religious practitioners, broke up ceremonies and seized religious objects. The cabildos that managed to survive until the triumph of the Cuban revolution in 1959 ironically fell victim to the new government's proscription of race-based organizations. Since the revolution had abolished racial discrimination, the argument went, historically black organizations were at best an anachronism and unnecessary, and at worst, divisive and racist. Thus most of the remaining cabildos were closed. ${ }^{60}$

The history of Carnival follows a similarly bumpy course. During the final war of independence, the colonial government pre-Lenten Carnival (the "white" carnival) was also suspended, but was reinstated by the U.S. occupation government. Blacks demanded the right to participate and eventually were granted a place, and by the early twentieth century the pre-Lenten Carnival combined elements of black and white traditions: white beauty queens on floats (usually with corporate or political sponsors) surrounded by black comparsas. The comparsas, which have been severely under-studied, were highly localized, based in the historically black and working class barrios marginales (marginal neighborhoods) of Havana, and to this day, the competition between them reflects longstanding place-based identities and rivalries. ${ }^{61}$ During the political and economic turmoil of the 19305 and 405 competing political factions often turned Carnival into a political arena, and many popular carnival 
songs (some of which are still sung today) contained subtle (or not so subtle) political critique or even campaign slogans.

While much of the nationalist elite saw black culture as anachronistic and atavistic, in the 19205 a section of the Cuban intelligentsia turned to Afrocuban culture as an authentic source of national cultural identity free of foreign influences. ${ }^{62}$ Pioneering ethnographers like Fernando Ortiz, Róomulo Lachatañeré and Lydia Cabrera painstakingly documented Afrocuban cultural and religious practices. ${ }^{63}$ Ortiz used his research to lobby for the reinstatement of the black comparsas in Carnival. ${ }^{64}$

As was true elsewhere in the Caribbean, unstable or dictatorial governments often feared that boisterous public cultural expressions like Carnival, that brought masses of people into the streets, would give way to something more seriously threatening, and in the 1950 s the dictator Fulgencio Batista again banned Carnival. The cultural fervor of the early years of the Cuban revolution included efforts to revive (as well as document) "authentic" popular cultural traditions like Carnival, while infusing them with socialist values. Fidel Castro proclaimed Cuba an "Afro Latin" nation and Africanbased cultural practices and religions were revalorized as national patrimony (although as culture and not as religion). In the early 1960 s the comandantes (commanders) paraded in what was billed as "Santiago-style" Carnival; a much-quoted aphorism from Che Guevara describes Cuba's as a "revolution with pachanga"(or "swing").

As part of the effort to inscribe Carnival into the revolutionary project, during the campaign for the 10-million ton sugarcane harvest in the 1970s, the authorities shifted Carnival from February to July so as not to interfere with the sugar harvest. During the severe economic crisis in the early 1990 s that followed the collapse of the Soviet Union, the government cancelled Carnival, and then reinstated it in $1995 .{ }^{65}$ By the late 1990s, as part of the government's efforts to package Cuban culture for touristic consumption, Carnival was made more "commercial". Traditional neighborhood-based comparsas alternate with floats bearing dancers from the re-opened Tropicana and other cabarets. Although these cabarets are all owned by the state, the floats resemble those from the pre-revolutionary carnival. All along the Malecón, the seafront drive along which the parade proceeds, there are now food and beverage kiosks that are open for much of summer, and several relatively new cabarets and discotheques (in hard currency) where people can go for live entertainment after the Carnival parades.

Carnival is actually not a single event but a series of parades and competitions (with panels of judges appointed by the Ministry of Culture) that take place throughout the country over a period of several weeks. Each municipality is given a specific date for its local Carnival, with the festivities in Havana (which usually extend over two or three weekends) as the culmination.

Although Carnival is promoted as something that belongs to all Cubans, it is hard to avoid the conclusion that it is, in fact, largely a "black" thing. Based on my observations of Havana's Carnival over several years, nearly all of the comparsa performers are black, and blacks are somewhat overrepresented in the boisterous crowds that line the Malecón to watch the parade. Like many black-identified cultural and musical forms, including popular musics like timba and reggaetón, many Cubans associate Carnival (and the street) with rowdiness, excessive consumption of alcohol, and the Cuban equivalent of "slackness", and it is subject to intense policing. ${ }^{66}$

The revival of Carnival and the "invention" of the Salida de los Cabildos, although directed at somewhat different audiences, are both part of the But this Afrocuban "revival" did not begin after the collapse of the Soviet bloc but has its roots in the 1980s. In 1986, the government established Casa de Africa, a combination museum and research center, to further the work of Fernando Ortiz (and house some of the artifacts he had collected). In that same year, dockworker Francisco Moya (popularly known 
as "Pancho Quinto") and some of his co-workers formed an "amateur" folkloric group called Yoruba Andabo, significant in that it revived the use of wooden boxes (cajones), a percussion instrument that had fallen out of use in the 1940s. Yoruba Andabo, which eventually gained "professional" status, set the stage for the folkloric "boom" of the 1990 .

The push to develop international tourism (which included a vast historical restoration effort in Old Havana) thus overlapped with a modest renewal of scholarship on Afrocuban culture and, cautiously, on race more generally. ${ }^{67}$ A scholarly symposium on Afrocuban culture produced the proposal to revive the Día de los Reyes celebration for Casa de Africa's tenth anniversary in 1996. Using a germinal essay by Fernando Ortiz as a guide, the museum professionals planned a parade and mapped out a route, and contracted folkloric performers to enact the parade. ${ }^{68}$ In several conversations and interviews, the professional staff reiterated a concern with authenticity and cultural preservation, and continually invoked Ortíz as a guiding and legitimizing force. ${ }^{69}$ However, it is almost certain that he never witnessed a Día de los Reyes parade himself: he was born in 1881, and thus would have only been a few years old when the event was banned by the Spanish authorities around 1884. Although when Ortíz wrote his essay in 1920 s he would have been able to find informants who had witnessed or participated in the previous century's celebrations, it does not appear that he sought any out; his descriptions of the processions are drawn largely from published accounts by costumbrista writers, and nineteenth-century European visitors to Havana.

In their efforts to faithfully recreate a nineteenth century event, the heritage professionals also looked at work by artists of that era such as Landaluze - the same sources consulted by Ortíz. Ironically, then, the colonialist gaze became a guide to cultural authenticity in the present. In particular, they drew upon a well-known lithograph by Landaluze, "El Día de los Reyes", that depicts an open-air plaza in Habana Vieja as a scene of carnivalistic excess. In this widely-reproduced print, as costumed and masked dancers whirl, a black man with an open shirt collar vigorously pounds a drum, while another lifts his arms skyward in abandon. ${ }^{70}$

At the same time, the museum staff understood that the procession had to "play" to contemporary audiences. The event's dramatization draws upon the established conventions of state-sponsored folkloric spectacles. It is selective and representative. The seeming spontaneity is highlychoreographed so that the parade hits numerous plazas to catch as many different groups of tourists as possible as they sit in cafes or make their way to other sights and spectacles.

But the presentation also relies upon embodied knowledge of folkloric performers; these "culture bearers" have different performative criteria and many have their own agendas. ${ }^{71}$ The artistic director, Daniel Rodriguez, is a religious practitioner whose professional career as a folkloric performer extends back to the early years of the Revolution. He views this as an opportunity to "open a space" for black public cultural production and to encourage a lot of young people to learn traditional music and dance. Many of the performers are children and teenagers whom he has taught, and he sees their participation in the Salida de los Cabildos as crucial to ensuring that this embodied knowledge gets transmitted to new generations and remains vital. ${ }^{22}$

There is thus some tension and confusion about who controls the spectacle, the museum professionals or the performers. In 2005, I witnessed one open clash when Natasha, the parade director, decided that the performance by Ojun D'gara, a group of folkloric performers who had made a several hour bus journey from a rural town in Matanzas province, was dragging. Natasha is a white professional whose knowledge of Afrocuban culture came primarily through courses she received as part of her job. With no warning, she abruptly signaled another group to start playing in the middle of a song by Ojun D'gara, in order to "move things along." The Matanzas performers stopped, confused, and let the other group continue. Natasha later told me that she had intended to ask Ojun D'gara to play 
again at another point in the parade, but she did not get a chance. The performers were offended by the way they had been treated, but did not openly challenge Natasha, as they were, after all, state employees and this performance was part of their monthly "quota". However, they decided that they had completed their contractual obligations and quietly packed up their instruments, and walked back to their bus. I chatted briefly with them, along with some of their Havana-based friends and relatives who had turned out to see them perform. Then they boarded the bus without much fanfare and headed back to Matanzas while the parade continued. ${ }^{73}$

Events like the Salida de los Cabildos evoke contradictory reactions from Havana residents and those most concerned with Afrocuban cultural production. Some folkloric performers and cultural observers I knew dismissed the event as a show for tourists. However, many of the performers, as well as some community residents, see it in a positive light, as a means of reclaiming and preserving cultural traditions that might otherwise be forgotten or marginalized. Daniel Rodriguez, the musical director, explained to me that he had made a conscious choice to "take advantage" (his term) of the opportunity. It is also, quite literally, temporary reclamation of an increasingly privatized public sphere, as more and more of Old Havana (and other World Heritage sites like Trinidad) is turned over to tourist-friendly enterprises and local residents often feel that their neighborhoods and cities no longer belong to them. Historic restorations have often been carried out with an eye towards tourists rather than the needs of local residents. The majestic plazas are lined with restaurants, cafes and stores that are beyond the means of most Cubans (although the upper floors of many of the buildings still contain residential apartments), and metal bollards help define and discipline the space. ${ }^{75}$ Several friends noted with some irony that while the centerpiece of the restoration of Plaza Vieja was a lavish water fountain, it was surrounded by a wrought-iron fence.

Black cultural performances in public spaces - even when sponsored by state cultural institutions -- still evoke anxiety and racialized fears of social disorder. ${ }^{76}$ Events that draw large crowds -- such as the revived Carnival celebrations -- are constructed as unruly and heavily policed. These attitudes are widely shared by many Cubans. Many of my Cuban friends disdainfully proclaimed that they never attended the Carnival parade on the Malecón because it was too noisy, rowdy and dangerous, and preferred to watch it on TV. They treated my interest in observing it firsthand as one of those idiosyncratic notions that foreigners are prone to, and reminded me to be on my guard. ${ }^{77}$ Black male bodies are treated as especially problematic. On two occasions, black male friends who had accompanied me to the Carnival parade ended up spending a night in police custody because they were not able to produce a carnet de identidad (national identity card) when stopped by the police. ${ }^{78}$

Open-air sites where rumba and other folkloric music/dance genres are performed usually have a visible police presence and the organizers often strive to ensure that performances start and stop on time and do not turn into all-day or all-night jam sessions. ${ }^{79}$ Although the Salida de los Cabildos is usually held on a weekday afternoon and draws relatively small crowds it is not completely controllable and often threatens to overspill its bounds. The parade is popular with local residents and Cubans who work in some of the numerous unglamorous jobs in the Centro Historico. As the procession passes, Cuban workers and residents lean out of their windows, spill onto the sidewalks, or take an impromptu break and join the procession in their work uniforms. (See Figure 7). The heritage professionals at Casa de Africa commented that in staging the parade, they had to be concerned about the crowd behavior since bystanders sometimes got too enthusiastic, and they were worried that if they did not keep the parade moving, it would turn into a free-for-all. ${ }^{80}$

Taken together, the parade and the dolls can help us understand some of the complex intertwinings of the ethnographic and the carnivalistic in contemporary Cuba. An ethnographic approach to the carnivalistic in Cuba would necessitate, of course, analyzing the perspectives and agendas of the various social actors engaged in the production and consumption of each of these performances or 
items, and the multiple contexts implied or involves. For example, it would be fascinating to more fully analyze the figurines and other souvenirs, and the cultural and political economiesy of their production and circulation. Similar items are sold in a variety of locales: at hard currency shops located in tourist areas, in hotel lobbies and museums, at open-air markets known as ferias, but also at hard currency shops in ordinary neighborhoods where few tourists go. In the case of the ferias, especially those outside of Havana, sometimes the artisans themselves are vendors, but most frequently the vendors are not the producers, so it would be interesting to know something more about how the artifacts are producedtheir production, and how the designs and styles are selected (whether by individual artisans working independently, through design codes or production quotas established by the Ministry of Culture or other government bodies, or a combination).

Likewise, there is need for more in-depth ethnographic research on folkloric performance in "late socialist" Cuba, and the life-world of folkloric performers in the special period and beyond. The few book-length studies that have been written to date are based on fieldwork conducted either prior to the special period or with émigré performers in the United States. ${ }^{81}$ How do individuals and ensembles navigate between commerce and cultural preservation, between the ritual sphere and the market?

My intention in leaving some rough edges and unanswered questions is to argue against intellectual maneuvers that artificially separate some of these productions as authentic (and thus innocent) and demean others as cynically opportunistic. The lines are much more blurred. As George Yúdice argues, grassroots social actors consciously make use of the same cultural symbols and performances that are promoted or presented by state institutions or nongovernmental organizations for their own ends. ${ }^{82}$ The Cuban social actors I have described here may participate in several registers of cultural performance: many, if not most, of the performers who enact

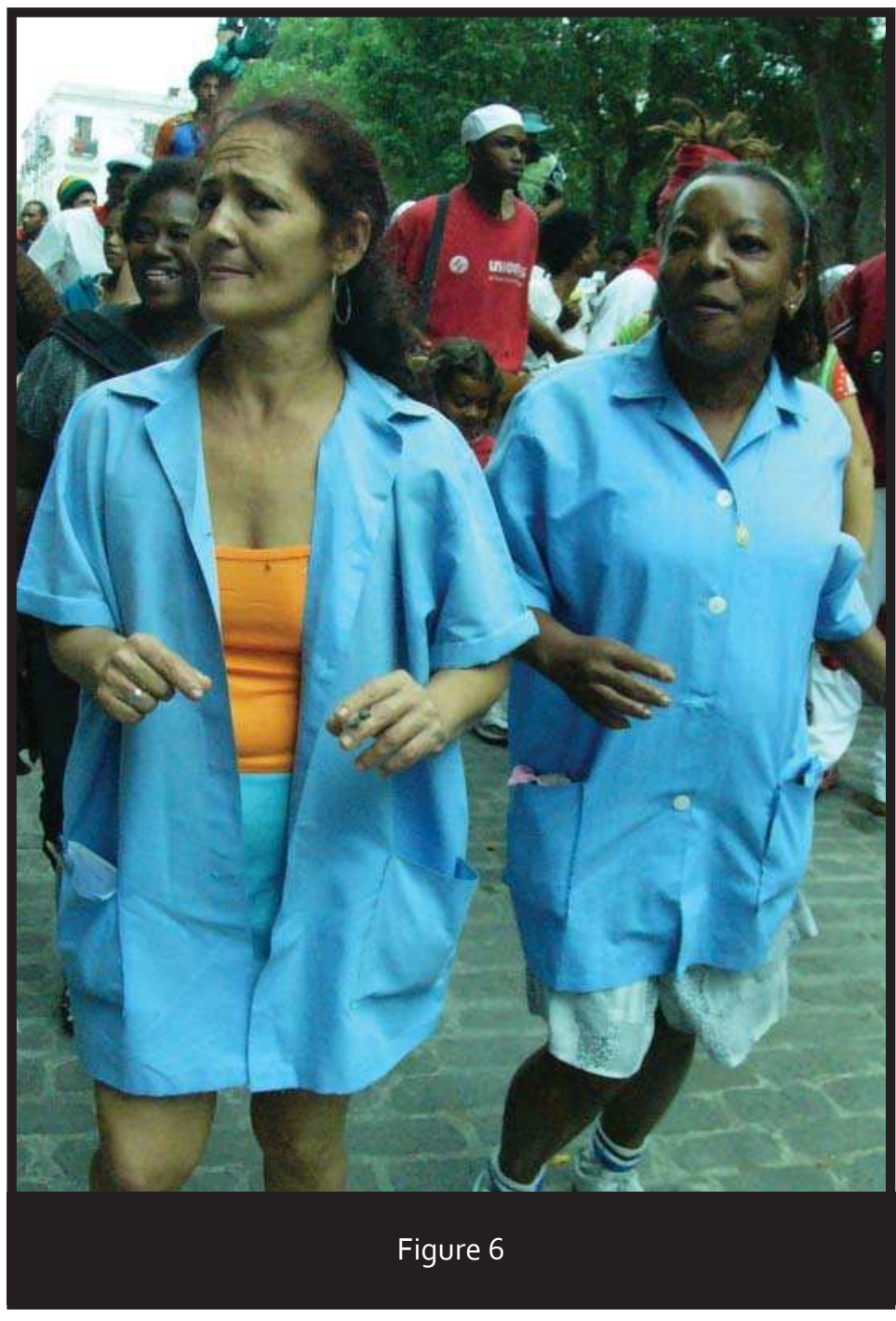
the staged Orisha dances in the Salida de los Cabildos are initiated priests and priestesses. ${ }^{83}$ Some are professional dancers or musicians who also perform in nightclubs and cabarets. The woman who enacts the role of a spiritualist or fortune teller in the Plaza may in fact be a respected healer in her community. The multiple agendas sometimes dovetail, overlap, intersect or clash. Tourist development and commoditized self-eroticization may seem like reasonable - if remote -- options to localized actors in the rural zones around Matanzas and Trinidad where most of the "Slave Routes" sites are located and where old slave quarters are still used as housing. Residents in one community I visited in rural Matanzas province have repurposed slave-era relics, including some that are on the Office of Patrimony's registry; for example, the huge metal cauldrons used for boiling sugar cane juice are used as water tanks. 
The un- or under-narratives nature of the ethnographic displays and spectacles may be unsettling, but it also allows me to make a different analytical point: that the scholarly text, the ethnographic display and the blatantly touristic commodity do not occupy completely separate realms but are closely interrelated registers through which slavery and its legacy are simultaneously silenced and consumed. I want to close with a comment made to me by Cuban historian Leyda Oquendo when I came to interview her for this project: she noted wryly that our own scholarship was part of the consumption. ${ }^{84}$

\section{References}

1. The present article draws upon papers I presented at the conference of the Association for the Study of the World African Diaspora (ASWAD) in Georgetown, Barbados, October 7-10, 2007, and the conference, Carnival: 'A People Art' and Taking Back the Streets, held at York University, Toronto, July 30 -August 3, 2008, and benefitted from the generous feedback of co-panelists and other participants. The analysis presented in this article has been sharpened by many conversations over the years with other students of race and Cuban culture, both in and out of Cuba, many of whom are cited in what follows. I am extraordinarily grateful to the two anonymous peer reviewers for Race and Ethnicity in a Changing World, who read the manuscript in record time and provided thoughtful and precise comments. They were models of what the peer review process should be. I was not able to fully utilize the many excellent suggestions they offered, but the article is much improved by my efforts to respond to them. Any deficiencies or weaknesses in the discussion are mine alone. I am also grateful to the editors of the journal for their unflagging enthusiasm and patience.

2. Trouillot, Michel R. Silencing the Past: Power and the Production of History. Boston: Beacon Press, 1995 p. 85

3. There is a growing body of scholarship about the problematic relationship between race and national identity during the last century and a half of Cuban history. Historian Ada Ferrer has argued that the status of Cuba's growing (mostly enslaved) black population vexed the nineteenth century independence movemen - see Ferrer, A. Insurgent Cuba: Race, Nation and Revolution, 1868-1898. Chapel Hill: University of North Carolina Press, 1999. See also Moore, R. Nationalizing Blackness: Afro-Cubanismo and Artistic Revolution in Havana, 1920-1940. Pittsburgh: University of Pittsburgh Press, 1997.; De la Fuente, A. A Nation for All: Race, Inequality, and Politics in Twentieth-Century Cuba. Chapel Hill: University of North Carolina Press, 2001., and Helg, A. Our Rightful Share: The Afro-Cuban Struggle for Equality. Chapel Hill: North Carolina Press, 1995.

4. The brochure distributed at the Museo Histórico de Guanabacoa is a case in point. The opening essay by Cuban scholar Marta Arjona extols the "immense aesthetic value" of the ceremonial objects, and expresses gratitude to "the children of Africa who have ... left upon our culture their indelible imprint." Marta Arjona, "Museum of Guanabacoa: A Wealth of Afrocuban Traditions." Introductory essay in Museum of Guanabacoa: A Wealth of Afro-Cuban Traditions (Museum catalog, Museo de Guanabacoa: Ciudad de la Habana, Cuba: no date), p. 9.

5. I use the term "cultural production" as a very broad rubric, encompassing material objects such as tourist souvenirs, as well museum exhibits and cultural performances.

6. Fernando Ortiz uses the terms "black carnival" and "white carnival" in his 1920 essay "La antigua fiesta del dia de los reyes," reprinted in Barnet, M. and Fernandez, A., eds. Ensayos Etnográficos Havana: Editorial de Ciencias Sociales, 1984, pp. 11-40.

7. Other discussions of the Cuban state's efforts to regulating cultural expression (including black identified cultural forms) are found in Perry, Marc. Consuming Blackness: Neoliberal Economies of Race in Late Socialist Cuba, unpublished manuscript., and Fernandes, S. Cuba Represent! Cuban Arts, State Power and the Making of New Revolutionary Cultures Durham, NC: Duke University Press, 2006., among others. More specific analyses of the state efforts to institutionalize "folklore" can be found in Vélez, Maria T. Drumming for the Gods: The Life and Times of Felipe Garcia Villamil. Philadelphia: Temple University Press, 2000., Hagedorn, K. Divine Utterances Washington, DC: Smithsonian Institution, 2001., and Hernandez-Reguant, A. Cuba's Alternative Geographies. Journal of Latin American Anthropology, 10(2), 2006, pp.275-313.

8. The concept of "encoding" is drawn from the work of cultural theorist Stuart Hall - Hall, S. Encoding/ 
decoding. In: Hall, S. Culture, Media, Language (1980) New York: Rutledge, pp.128-138. The concept of "cultural performance" was first articulated by anthropologist Milton Singer in 1955. For Singer, the term cultural performance encompasses both those activities usually defined as "cultural" (such as theater and music) but also festivals and rituals (including more private ones) that are usually categorized as "religion" or "ritual". See Singer, Milton The Cultural Pattern of Indian Civilization: A Preliminary Report of a Methodological Field Study. The Far Eastern Quarterly 15(1), 1955, pp. 23-36.

9. There is a large and growing bibliography of anthropological and other critiques of how cultural property (including artifacts, performance and sites) and cultural identities are shaped by tourism and other neoliberal approaches. A good starting point is Barbara Kirshenblatt-Gimblett's essay, "Objects of Ethnography" - see Kirshenblatt-Gimblett, B. Objects of Ethnography. In: Karp, I and Lavine, S. eds. Exhibiting Cultures: The Politics and Poetics of Museum Displays. Washington: Smithsonian Institution, 1998, pp. 386-443. Kirshenblatt-Gimblett further develops some of these arguments in her book Destination Culture: Tourism, Museums and Heritage - see Kirshenblatt-Gimblett, B. Destination Culture: Tourism, Museums and Heritage Berkeley: University of California Press, 1998. Other useful works include Brown, Michael F. Who Owns Native Culture?, Cambridge, MA: Harvard University Press, 2004. Audra Simpson's forthcoming work on the Kahenwake Mohawk and Jessica Cattelino's study of the Florida Seminole explore the neoliberal treatment of indigenous identities in North America. See Simpson, A. To the Reserve and Back Again: Kahnawake Mohawk Narratives of Self, Home and Nation. Durham : Duke University Press, forthcoming, and Cattelino, J. Casino Roots: The Cultural Production of TwentiethCentury Seminole Economic Development. In: Hosmer, B. and O'Neill, C., eds. Native Pathways: Economic Development and American Indian Culture in the Twentieth Century. Boulder: University of Colorado Press, 2004, pp. 66-9o. As Quetzil Castañeda and other scholars have argued, anthropology (and especially archaeology) is often complicit in the touristic reprsentation and consumption of racialized identities. See, among other works, Castañeda, Q. In the Museum of Maya Culture: Touring Chichen Itza. Minneapolis: University of Minnesota Press, 1996.

10. In recent years, scholars both inside and outside Cuba have begun to challenge (and break) the official silences around race. A signal publication was the 1990 publication of Cuban scholar Tomas Fernandez Robaina's book El Negro en Cuba 1902-1958 - see Fernandez Roba, T. El Negro en Cuba 1902-1958. Havana: Edition de Ciencias Sociales. 1900. - but as the title makes clear, Robaina's analysis stops at the eve of the revolution. Since the mid-1990s, several U.S.-based and other international scholars have explored racial dynamics after the 1959 revolution. Alejandro de la Fuente's A Nation For All (ref. 3_includes several chapters on post-revolutionary Cuba, and race is a central theme in Robin Moore's Music and Revolution: Cultural Change in Socialist Cuba - see Moore, R. Music and Revolution: Cultural Change in Socialist Cuba. Berkeley: University of California Press, 2006 - as does Nadine Fernandez's book Revolutionizing Romance: Interracial Couples in Contemporary Cuba - Fernandez, N. Revolutionizing Romance: Interracial Couples in Contemporary Cuba. New Brunswick, NJ: Rutgers University Press, 2010. See also, among other sources: De la Fuente, A. The New Afro-Cuban Cultural Movement and the Debate on Race in Contemporary Cuba. Journal of Latin American Studies. 40(November) 2008, pp.697-720; Fernández, N. The Changing Discourse of Race in Contemporary Cuba. Qualitative Studies in Education. 14(2), 2001, pp.117-132; and Hernández-Reguant, A. Cuba's Alternative Geographies (ref.7). Within Cuba, several researchers at the Centro de Antropología conducted a long-term study of race - the publications they have produced include Espina Prieto, R. and Rodriguez Ruiz, P. Raza y desigualdad en la Cuba actual (Race and inequality in Cuba today). Temas, 45(Jan-March), 2006, pp. 44-54. Roberto Zurbano, an essayist and vice-president of the National Union of Cuban Artists and Writers (UNEAC), has published several pieces on race, including Zurbano, R. El triángulo invisible del siglo XX cubano: raza, literatura y nación (the invisible triangle of the Cuban 2oth century: race, literature and nation). Temas 46(AprilJune), 2006, pp. 111-123.

11. For background on Cuba's "touristic turn", and some of the social and cultural implications, see Schwartz, R. Pleasure Island:Tourism and Temptation in Cuba, Lincoln, Nebraska: University of Nebraska Press, 1997. Both Cuban government sources and external observers have tabulated the ups and downs of Cuba's tourist sector over the past decade, with foreign (especially U.S.-based) sources often making dire predictions based on periodic downturns. Over the 1990 s tourism grew to around 2 million visitors annually, with tourism revenues accounting for a substantial share of the national economy.

12. There was a noticeable slump in international tourism overall and tourism to Cuba in particular following the September 11, 2001 attack on the World Trade Center but tourism appears to have recovered somewhat. According to Cuban government sources, there were 2.3 million visitors in 2008 - see: Grogg, 
P. Big Hopes for Tourism Industry. [Online] 2009 (Retrieved July 12, 2009) Interpress Service (IPS) Url http: http://ipsnews.net/news. asp?idnews $=46218$

13. The Cuban government had established farmers' markets in the early 1980 s but they were closed after a few years.

14. See Henken, T. Condemned to Informality: Cuba's Experiments with Self-employment During the Special Period, Ph.D. dissertation, Stone Center, for Latin American Studies, Tulane University; Sacchetti, E. Experimenting with Change: An Anthropological Perspective on Cuban Micro-Enterprise. Cuba In Transition. 16, 2008, pp. 301-315.

15. Pérez-López, Jorge F. Cuba's Second Economy. New Brunswick, NJ: Transaction Books, 1995.

16. See Gordy, K. Sales+Economy+Efficiency=Revolution? Dollarization, Consumer Capitalism and and Popular Responses in Special Period Cuba. Public Culture, 18(2), 2006, pp. 383-412.

17. I use the term "hard currency stores" throughout, although this label is not used in Cuba. Cuba currently has two official currencies: pesos cubanos ("Cuban pesos", also called moneda nacional, "national money") and pesos convertibles ("convertible pesos") that can be used at hard currency stores. Prior to the special period, ordinary Cubans were only allowed to use moneda nacional, and diplomats and party officials were able to use U.S. dollars at highly restricted hard-currency stores that were popularly called diplo-tiendas. After the Cuban government legalized the possession of U.S. dollars by ordinary citizens in 1993, the stores were colloquially called "dollar stores" and although ordinary Cubans were allowed to enter, few had the means to make purchase. In 2004, in retaliation for the Bush Administration's tightening sanctions against Cuba, the Cuban government declared U.S. dollars would no longer be accepted in retail stores, and switched to a currency called the peso convertible (abbreviated as CUC) that had been introduced in a limited way a few years earlier. The name is extremely ironic as this currency is not accepted anywhere outside of Cuba. U.S. dollars, Euros and other foreign currencies can be exchanged for CUCs or moneda nacional at currency exchanges and banks but the government levies an additional $20 \%$ fee on U.S. dollars.

18. MISSING!

19. The passion for acquiring consumer goods was often satirized in Cuban popular culture. A highly gendered critique is found in the song "La Shopimaniaca" (the female shopping maniac) by Los Van Van (from their 1998 CD Te Pone La Cabeza Mala). The male narrator of the song exasperatedly but affectionately laments his girlfriend's endless purchases in dollar stores.

20. Espina Prieto, R. and Rodriguez Ruiz, P. Raza y desigualdad en la Cuba actual (Race and inequality in Cuba today). Temas, 45(Jan-March), 2006, pp. 44-54.

21. A discussion of sex tourism is beyond the scope of this article, but numerous scholars both in and outside of Cuba have noted the racialized contours of sex work in contemporary Cuba - for example, Lucia Cabezas, A. Discourses of Prostitution in Cuba. In: Kempadoo K. and Doezema, J. eds. Global Sex Workers: Rights, Resistance and Redefinition, New York: Routledge, 1998, pp. 79-86.; and Fusco, Hustling for Dollars: Jiniterismo in Cuba. In: Global Sex Workers: Rights, Resistance and Redefinition, New York: Routledge, 1998, pp. 151-166.

22. See Nadine Fernadez's critique of the Centro de Antropologia's study of race in Fernandez (ref.10). See also De La Fuente (ref. 3)

23. See, for example, Perry, M. Consuming Blackness (ref. 7) and Hernandez-Reguant, A. Multi-Cubanidad. In: Hernandez-Reguant, A. ed. Cuba in the Special Period: Culture and Ideology in the 1990s. New York: Palgrave MacMillan, 2009, pp. 62-88.

24. See Hagedorn, K. Divine Utterances (ref. 7), Moore. R, Music and Revolution (ref.3)

25. State support or recognition of Afrocuban religious practitioners is not as developed in Cuba as it is in Salvador de Bahia, Brazil, where the Ministry of Culture has sponsored events honoring some of the most influential Candomble priestesses.

26. Cubans use a fluid and multi-tiered system of racial categorization in everyday speech. Terms like mulata and prieta (dark) are widely used, both as physical descriptors and terms of endearment that may not reflect a person's appearance. I am Euro-American, and yet Cuban friends will often greet me as "mi negra" (literally, "my black woman)". According to longtime observers, the Tropicana's performative aesthetics have not changed substantially in the fifty years since the Cuban revolution - including the extravagant and revealing costumes and choreography, and the selection of dancers by physical appearance: tall, long-legged and "mixed race" but light skinned. There are few if any dark-skinned blacks or whites. Although in the early twentieth century the Tropicana was run by the Mafia and associated with their drug and prostitution businesses, it escaped the fate of other nightclubs, most of which were 
closed shortly after the revolutionary government took power in 1959, because it was so popular with Cuban audiences. It was eventually closed in 1968 but reopened in 1970, and was heavily promoted when foreign tourists started arriving in large numbers in the 1990s. In 2003, the club's management announced that they were changing the show, replacing the music/dance revue "Tropicana: La Gloria Eres Tu" (Tropicana, the glory is you), in which the showgirls played a prominent role, with a show called "Tambores en Concierto" (drums in concert), focusing on the "roots" of Cuban rhythms. See Vanessa Arrington, "Havana's Tropicana switching rhythms, easing show of flesh." Associated Press, November 2, 2004. Elizabeth Ruf Maldonado, who conducted research at the Tropicana in the early to mid 1990s, argues that the Tropicana's popularity with Cubans is due in part to the fact that the mulata embodies the national ideal of racial mixing or mestizaje and is thus a patriotic symbol, not only an object of desire. See MaldonRuf, E. Que linda es Cuba!: Issues of Gender, Color, and Nationalism in Cuba's Tropicana Nightclub Performance. TDR, 41(1), 1997, pp. 86-105. Kaifa Roland notes that female dancers tend to be "mulaticized" by headdresses and hairstyles that obscure their race. See Roland, K. Tourism and the Negrificacion of Cuban Identity. Transforming Anthropology, 14(2): 151-162, 2006 p. 158-9.

27. The correct terminology to describe African-origin or black-identified cultural practices in Cuba is the subject of some debate. The pioneering (and often problematic) scholar Fernando Ortiz used the term "Afrocuban religions," and other early twentieth century writers often referred to "Afrocuban cults". In recent years scholars and museum and heritage professionals have adopted the term, "religions of African origin" (although the word "cult" still appears from time to time). For a further discussion of this evolution, see Pedroso, Louis A. Las exposiciones de 'cultos afrocubanos' y la necesidad de su reconceptualización. Catauro: Revista Cubana De Antropología 3(5), pp. 126-141.

28. I use "festive ethnicity" here as a shorthand expression for the ways in which both state and non-state actors use performances, festivals, exhibitions and other visual and performative means to forge or reinforce ethnic, cultural, national, racial and other identities. The upbeat, celebratory tone of the narratives and performances effectively pre-empts or precludes any critical interrogation, and often serves the purpose of masking persistent inequalities with a veneer of harmonious inclusivity. In the hands of state institutions, festive ethnicity often undergirds specific nationalist projects, including official multiculturalism. On the other hand, ethnic and racial minorities can use festive ethnicity to challenge exclusionary practices and stake their own claims. There are many recent articles and a few books that provide nuanced analyses of these phenomena. David Guss' The Festive State: Race, Ethnicity and Nationalism as Cultural Performance examines festivals and performance in Venezuela - see Guss, D. The Festive State: Race, Ethnicity and Nationalism as Cultural Performance. Berkeley: University of California Press, 2000. Several of the chapters in Lisa Maya Knaver and Daniel Walkowitz, eds. Contested Histories in Public Space: Memory, Race and Nation explore these concerns in a variety of case studies see Maya Knauer, L. and Walkowitz, D. eds. Contested Histories in Public Space: Memory, Race and Nation. Duke University Press, 2009 - for example, Amar, P. Saving Rio's "Cradle of Samba": Outlaw Uprisings, Racial Tourism, and the Progressive State in Brazil. pp. 249-279; and Poole, D. Affective Distinctions: Race and Place in Oaxaca. pp. 197-227. See also Kuutma, K. Festival as communicative performance and celebration of ethnicity. Folklore: Electronic Journal of Folklore, 7, [online] pp. 79-86. 1998. (Retrieved July 12, 2009). (Url: http: www.ceeol.com.); and Steiner, C. The Invisible Face: Masks, Ethnicity and the State in Cote d'Ivoire. In: Roy Richard Grinker and Christopher Steiner (eds), Perspectives on Africa: A Reader In Culture, History and Representation. Oxford: Blackwell Press, 1997 pp. 671-679.

29. My translation. The original statement by Martí is "No hay odio de razas, porque no hay razas. .... Cubano es mas que blanco, mas que mulato, mas que negro..."

30. "La Vida es un Carnaval" (words and music by Victor Daniel). The song appears on at least two CDs by Delgado that were released in 2000: La Primera Noche (Caribe Productions), and La Formula (Ahi Nama Music). Delgado's music video of the song features hundreds of Cubans (mostly young women in skimpy clothing) gyrating and waving their arms as they sing and dance to the chorus. The song was also recorded by Celia Cruz, and numerous other performers.

31. Harvey, Daina C. (Re)Creating Culture Through Tourism: Black Heritage Space in New Jersey. In: Melanie Smith, Melanie K. ed. Tourism, Culture and Regeneration. Oxford: Oxford University Press, 2007. pp. 59-68.

32. Efforts to "preserve", renovate and/or restore urban sites such as New York City's Union Square Park have often been criticized for putting the interests of real estate developers and upper-middle class professionals over those of local residents. Aesthetic and design choices - reflecting elite visions and often enhancing the ability to secure and survey public spaces - have also come under critical scrutiny. See Deutsche, R. Evictions: Art and Spatial Politics. Cambridge: MIT Press, 1996.; Page M. and Mason, R. 
Giving Preservation a History: Histories of Historic Preservation in the United States. New York and London: Routledge, 2004; and Herzfeld, M. A Place in History: Social and Monumental Time in a Cretan Town.

Princetown: Princetown University Place, 1991.

33. See Michael Herzfeld (ref. 32)

34. In Spanish, the Oficina del Historiador de la Ciudad de la Habana (OHCH).

35. For a more thorough discussion of the role of the $\mathrm{OHCH}$ in the reconstruction of Old Havana, and the powers of the agency, see Hill, M. Globalizing Havana: World Heritage and Urban Redevelopment in Late Socialist Cuba. Unpublished PhD dissertation, University of Chicago, 2004.

36. Lowenhaupt Tsing, A. In The Realm of the Diamond Queen. Princetown: Princetown University Press, 1993

37. The museum narrative contains its own gaps and silences. The Castillo remained in use as a prison until the 1980s, a fact that is not mentioned by the guides who take visitors to see the cells where slaves were kept. I am indebted to Julio Moracen Naranjo and Andres Reyes Rodriguez for supplementing my understanding of the site.

38. On the several occasions that I have taken one of the higher-priced air-conditioned buses that run between Havana and Varadero, I was one of the few people who disembarked at Matanzas.

39. Costumbrismo is a form of literary or visual representation that focuses on scenes of everyday life, or "local color". It is derived from the Spanish word for customs -- costumbres.

40. The manifold ironies of the marketing of Che have been dissected by numerous scholars, including Ariana Hernandez-Reguant - see Hernandez-Reguant, A. Copyrighting Che: Art and Authorship under Late Cuban Socialism. Public Culture 2004 16(1) pp. 1-30; Skoller, J. The Future's Past: Re-imaging the Cuban Revolution. Afterimage. 26. 1999

41. The complexities of museumized representations of Afrocuban religions are discussed by Luis Pedroso. Las exposiciones de 'cultos afrocubanos (ref. 27). A more detailed analysis of the ethnographic displays in the Museo de Guanabacoa can be found in Lisa Maya Knauer, "Afrocuban Religion in Cuban Museums" in Daniel Walkowitz and Lisa Maya Knauer, eds. Contesting History in Public Space (ref 28)

42. The imbrication of carnivalistic and ethnographic is not unique to Cuba: I purchased my Barbadian "Mammy" doll from the gift shop at the National Museum.

43. See Kutzinski, V. Sugar's Secrets: Race and the Erotics of Cuban Nationalism. Charlottesville: University Press of Virginia, 1993

44. I want to thank Tomas Fernandez Robaina for pointing me in the direction of the Landaluze paintings in the Museo de Bellas Artes.

45. In most of the African-derived religions practiced in Cuba, white represents purity, and participants in religious ceremonies often wear white or light colors. In la regla de ocha (santeria), new initiates (iyawos) dress exclusively in white for a year, and in both ocha and the Congo-derived practices colloquially referred to as palo monte or simply palo, initiates wear beaded necklaces that represent specific guardian spirits or divinities (called orishas in la regla de ocha and nkisi in palo). Cigars have many uses in religious contexts. Certain orishas, and eguns or muertos (spirits of the deceased) favor cigars, and participants in religious ceremonies frequently smoke cigars in an effort to attract those deities or spirits, or place cigars on their home altars. There are several reliable sources on Afrocuban religious practices and symbolism, including Mason, M. Living Santeria: Rituals and Experiences in an Afro-Cuban Religion. Washington, DC: Smithsonian Institution, 1992. and Ramos, M. The Lukumi Pantheon: The Orishas Worshipped by the Lukumi. [Online] (Retrieved on 8 July 2009] Url: http://ilarioba.tripod.com/articlesmine/Pantheon.htm.

46. Most of the staged performances of music and dance from the palo/Kongo traditions depict scenes of slaves being brutalized by their masters or overseers (as all the performers are black), and then banding together and using spiritual powers to vanquish their oppressors and liberate themselves. See Moore, R. (ref. 3) for a discussion of the role of black musicians in the nineteenth and twentieth centuries.

47. I have not found a widely-used Cuban name for these dolls. Some have suggested that the label "la negra Francisca" is often used.

48. Lane, J. Blackface Cuba, 1840-1895. Philadelphia: University of Pennsylvania Press, 2005. My reading of the marquillas draws upon Kutzinski's analysis, in Sugar's Secrets (ref. 43), and that of Alison Fraunhar - see Fraunhar, A. Marquillas cigarreras cubanas: Nation and Desire in the Nineteenth Century. Hispanic Research Journal. 9(5), 2008, pp. 458-478. For a fuller discussion of the "mammy" or "Aunt Jemima" image in U.S. popular culture and racial imaginings, see Turner, Patricia A. Ceramic Uncles \& Celluloid Mammies: Black Images and Their Influence on Culture. New York: Anchor Books, 1994.; and WallaceSaunders, K. Mammy: A Century of Race, Gender and Southern Memory. Ann Arbor: University of Michigan Press, 2006. An early treatment of the subject can be found in Dubin, Steven C. Symbolic Slavery: Black 
Representations in Popular Culture. Social Problems, 34(2) 1987, pp. 122-140.

49. One of the most explicit depictions of the racial and gender codes is a series entitled "The Birth of the Mulata", which begins with the sexual relationship between white man and black woman, and progresses through the "coming out" of the mulata as an alluring young woman. See Kutzinski, Sugar's Secrets, (ref.

3.)

50. See Kirshenblatt-Gimblett In: Karp, I and Lavine, S. eds. (ref. 9 pp. 386-443). According to the director of the Museo Histórico de Guanabacoa, many of the museum's early acquisitions of Afrocuban religious artifacts were donated by individuals who were not themselves religious but whose deceased relatives had been devotees - a result, perhaps, of the revolution's early avowedly atheistic stance and discouragement of religious practice (Grisel Fraga, interview with author, August 2005). Casa de África, on the other hand, acquired part of Fernando Ortiz' personal collection after his death. While Ortiz in his later years obtained religious items directly from his informants, his collection started with items that had been confiscated by the police when they broke up ceremonies. For a discussion of the contradictory nature of Ortiz's ethnographic work and in particular, his beginnings as a Lombrosian criminologist, see Bronfman, A. Measures of Equality: Social Science, Race and Citizenship in Cuba, 1902-1940. Durham: University of North Carolina Press, 2003. The Museo Montaner de Antropologia, housed in the Calixto Garcia Hospital, still houses a small collection of Afrocuban religious items that are a remnant of a "criminal ethnology" exhibit that dates back to the 1930s, when medical training included learning how to recognize potentially criminal behavior and individuals. The museum is only open by appointment, and is, according to hospital staff, still occasionally used for teaching purposes.

51. This account was related to me by an audience member at a panel where I presented an early version of this paper, at the conference of the Association for the Study of the World African Diaspora (ASWAD), in Barbados in October 2007. The speaker identified herself as African American but I unfortunately did not note her name.

52. Alexis Esquivel Bermudez, interview with author, June 2007. Esquivel was one of the first contemporary Cuban artists still residing in Cuba to offer critical perspectives on race in Cuba. In 1997, he curated a controversial and critically acclaimed exhibit entitled "Queloide I", ("keloid" is a medical term describing scar tissue; the show's title reference to the scars slaves bore as a result of whippings) followed by a show entitled "Ni Músicos Ni Deportistas" (neither musicians nor athletes). The Queloides shows (the most recent exhibit opened in April 2010) and Esquivel's own artwork are discussed in Fernandes, S. (ref. 7), and De la Fuente, A. (ref. 3).

53. Ortiz, F. Cuban Counterpoint: Tobacco and Sugar. Translated by Harriet Onis. Durham, NC: Duke University Press, 1995.

54. It is important to specify that this discussion primarily concerns Havana's carnival. Eastern Cuba, and particularly Santiago de Cuba, has a somewhat separate and distinctive carnival tradition marked by the region's proximity to Haiti, and other large cities have local carnivals. While Havana is the capital city and its carnival to a degree represents a "national" carnival, most Cuban scholars (and many ordinary citizens) consider Santiago's carnival to be more "authentic". The critique of Havana's carnival as too commercial dates back several decades, as noted by Robin Moore in the one chapter he devotes to comparsas and Carnival in the early zoth century. It is also reflected in the paucity of contemporary scholarship about Havana carnival by either Cuban or foreign writers. The chapter on Cuba in Judith Bettelheim's authoritative work on Caribbean festivals focuses exclusively on Santiago's Carnival. Another frame for exploring the dialectic of the ethnographic and the carnivalesque is thus the relationship between national and local. See Nunley J. and Bettelheim, J. Caribbean Festival Arts: Each and Every Bit of Difference. Seattle: University of Washington Press, 1988. Bettelheim also edited a relevant volume - see Bettelheim, J. Cuban Festivals: A Century of Afro-Cuban Culture. Princeton, NJ: Markus Wiener Publishers, 2001 - her own two essays in this volume also concentrate upon Santiago.

55. See Howard, Philip A. Changing History: Afro Cuban Cabildos and Societies of Color in the Nineteenth Century. Baton Rouge: Louisiana State University Press, 1998. His work builds upon Fannie Rushing's unpublished doctoral dissertation - Rushing, F. Cabildos de Nación, Sociedades de la Raza de Color: AfroCuban Participation in Slave Emancipation and Cuban Independence 1865-1895. University of Chicago, 1992. Both Howard and Rushing argue that the cabildos allowed blacks to both retain cultures and identities and forge new ones. George Brandon, in Santeria from Africa to the New World: The Dead Sell Memories - Brandon, G. Santeria from Africa to the New World: The Dead Sell Memories. Bloomington: Indiana University Press, 1997 - argues that it was in the urbanized setting of the cabildos that the modern religion known as santeria took shape, as free and enslaved blacks, often from different cultural 
backgrounds, pieced together African religion and spiritual practices under the nominal sponsorship of the Catholic Church.

56. See Ferrer, A. (ref. 3)

57. See Moore, R. (ref. 3)

58. Felix "Pupy" Insua, Cuban folkloric performer, personal communication, September 2005 (New York City); Juan Bencomo, master drum maker, personal communication, August 2005 (Havana, Cuba).

59. For further discussion of the PIC and the "war" of 1912, see (ref. 3 ). The PIC remains a controversial subject in Cuba, but some recent publications have begun to breach the long silence. Filmmaker Gloria Rolando's 2001 documentary Roots of My Heart was followed by Silvio Castro Fernandez's 2002 book, El Masacre de los Independientes de Color en 1912 - Castro Fernandez, S. El Masacre de los Independientes de Color en 1912. Havana: Editorial de Ciencias Sociales, 2002. This was the first substantial scholarly work published in Cuba focused entirely on the PIC, and it is notable that the title of the book, which carries the imprimatur a state-run publishing house, uses the word "massacre." In 2008, the centenary of the formation of the $\mathrm{PCl}$, the government allowed a plaque to be mounted on the door of the home occupied by founder Evaristo Evanoz in Habana Vieja.

6o. This is very similar to the role blacks were allowed to play in New Orleans' Mardi Gras.

61. Filmmaker Gloria Rolando's 2000 documentary El Alacrán (the scorpion), examines the history of Carnival and specifically one comparsa, El Alacrán, founded in 1908 and dedicated to the deity Yemayá.

62. See Moore, R. (ref. 3)

63. Starting in the late nineteenth century, most middle-class and educated Blacks sought to gain social acceptance by distancing themselves from these "backward" cultural practices. Rómulo Lachatañeré (1909-1952) was one of the first black Cuban intellectuals to write about Afrocuban religion. Both Ortiz and Cabrera were white; they were also brother and sister-in-law. Lachatañeré's first book, O mio Yemaya (published in 1938) was a path-breaking collection based on extensive oral history interviews with a santero (santeria priest). It was republished in English as Afro-Cuban Myths: Yemayá - Lachatañeré, R. Afro-Cuban Myths: Yemayá And Other Orishas. New York: Markus Weiner Publishers, 2006. Lachatañeré also wrote El sistema religioso de los afrocubanos - Lachatañeré, R., El sistema religioso de los afrocubanos. La Habana: Ciencias Sociales, 2001 [1942]; and Manual de Santería - Lachatañeré, R., Manual de Santería, La Habana: Editorial de Ciencias Sociales, 1995. Lydia Cabrera wrote over a dozen books on Afrocuban religions. Her first book, originally published in French in 1936 when she was studying in Paris, was Cuentos Negros de Cuba - Cabrera, L. Cuentos Negros de Cuba. Ediciones Universal, 1993 (1936). During the 1940 and 1950 s she conducted extensive fieldwork in Matanzas province, including supervising field recordings of religious music. She published two substantial volumes in Cuba, the massive 1954 work on santeria El Monte - Cabrera, L. El Monte. Ediciones Universal, 1995 (1954) and a linguistic study of ritual language Anagó: El Vocabulario Lukumí - Cabreara, L. Anagó: El Vocabulario Lukumí. Ediciones Universal, 1996. She left Cuba in 1959 and her remaining books were published in the United States. For a thorough assessment of Cabrera's scholarship and her legacy, see. Rodríguez-Mangual, Edna M. Lydia Cabrera and the Construction of an Afro Cuban Cultural Identity. Durham: University of North Carolina Press, 2004. Rodríguez-Mangual argues that Cabrera's work, which blurs narrative and ethnography, is not simply a continuation of Ortiz's efforts but marks an important shift in positioning Black Cubans as subjects and authors of their own narratives, and not simply objects of the (white) scholarly gaze.

64. See Moore, R. (ref. 3)

65. See Sanchez, R. Carnaval in Cuba, though less grandiose, remains a tradition. [Online] Url: http://www.sunsentinel.com/news/nationworld/sfl-flbcuba081osbaug10,0,1858314.story (South Florida Sun-Sentinel)

66. See Roland, K. (ref.26, pp 1-162).

67. In the 1980s, Cuban publishing houses began a modest revival of interest in Afrocuban themes and over a period of several years reprinted several volumes of Ortiz' work. At the same time, contemporary researchers like Natalia Bolivar, Tomas Fernandez Robaina, Lazara Menendez and others published books and articles on race and Afrocuban religion. For a fuller discussion of the Afrocuban "revival", see Hernandez-Reguant A. (ref. 23)

68. Ortiz, F. (ref. 6, pp. 41-78) - the essay was originally published in 1920 and republished several times during Ortiz' lifetime.

69. As noted earlier, Cuban scholars usually uncritically celebrate Ortiz for his "rescuing" of Afrocuban cultural practices. His training as a Lombrosian criminologist, is usually glossed over, treated as a "phase" or completely separate from his later conversion to Afrocubanismo, or ignored. For a critical appraisal 
of Ortiz's work and legacy, see Bronfman, A. Measures of Equality: Social Science, Citizenship and Race in Cuba, 1902-1940. Chapel Hill: University of North Carolina Press, 2004.

70. Interested readers can view the image online at INCOMPLETE!

71. The term portadores culturales, which literally translates as "culture bearers", is used widely by Cuban scholars, heritage and museum professionals, and occasionally by performers themselves.

72. Daniel Rodriguez, personal communication, January 2004, 2005 and interview by author, August 2006.

73. Professional musicians and musical groups belong to one of the state cultural enterprises (empresas) that fall under the aegis of the Ministry of Culture. The empresas are a cross between a state union, a professional guild, an management company and an employment agency. In theory, the empresa arranges performances and pays the musicians a monthly stipend based on a minimum quota of engagements, and arranges transportation, meals and accommodations when necessary. In practice, performers are often responsible for making their own arrangements.

74. An interesting comparison can be drawn with Pelourinho, in Salvador da Bahia, Brazil, also a UNESCO World Heritage site, which got its name from the whipping post (pillory, pelourinho in Portuguese) used for the public punishment of slaves. Pelo, as it is called by residents and tourist brochures alike, has continued to be home to a majority black (and poor) population. After Pelourinho received designation as "patrimony of humanity", many local residents were displaced for the "restoration" of historical buildings (some were simply bought out; others were temporarily rehoused and then allowed to return). Clarindo Silva, longtime resident and restaurant owner in Pelourinho, interview, June 1, 2009. See Collins, J. But What If I Should Need to Defecate In Your Neighborhood, Madame? Empire, Redemption, and the 'Tradition of the Oppressed' in a Brazilian World Heritage Site. Cultural Anthropology. 23(2), 2008 pp. $279-328$

75. The bollards block off vehicular traffic, creating pedestrian zones, which are pleasing to tourists but not always favored by Havana residents, especially truck drivers, taxi drivers, and others whose livelihoods depend upon their maneuvering vehicles through Old Havana to deliver goods to stores or the nearby wharves. Tourists who take taxis to or through the historic district often find that getting from one point to another is a laborious process as many streets are blocked off.

76. See Fernandes, (ref. 7) and Marc Perry (ref. 7)

77. These fears were not entirely groundless. In 2001, while standing in line to pass through the police barricade and enter the Carnival stands, my small backpack was slashed with a knife or razor blade although nothing was stolen as I was not carrying a wallet.

78. Racial profiling by Havana's police has been noted by numerous observers including Fernandes S. (ref. 7) and Perry. M, (ref. 7). A more in-depth discussion of rumba, race and social control can be found Maya Knaver, L. Racialized culture and translocal counterpublics: rumba and social disorder in New York and Havana. In: Cervantes Rodriguez, M., Grosfoguel R. and Mielants, E. eds. Caribbean Migration to Western Europe and the United States: Essays on Transnationalism, Identity, and Citizenship. Philadelphia: Temple University Press, 2009, pp. 131-168.

79. Personal communication, various.

80. I am referring specifically to works on folkloric performance, not on Afrocuban religion more generally, as there have been several excellent books based on research conducted in the last two decades. There are some excellent articles and book chapters on these themes, based on more recent research including Delgado, K. Spiritual Capital: Foreign Patronage and the Trafficking of Santeria. In: Hernandez-Reguant, A. (ref. 23, pp. 51-67), and a few chapters in Moore, R. Music and Revolution (ref. 3)

81. Yúdice, G. The Expediency of Culture. Minneapolis: University of Minnesota Press, 2003

82. Daniel Rodriguez, interview with author, August 2006.

83. Leyda Oquendo, interview with author, January 2007. 


\title{
South Asian Mobilisation in Two Northern Cities: A Comparison of Manchester and Bradford Asian Youth Movements
}

\author{
Dr. Anandi Ramamurthy, Univesity of Central Lancashire
}

\begin{abstract}
Anti-racist movements develop and maintain their energy through the establishment of local, grass root networks. To date research on the anti-racist movement in Britain has focussed on the creation of national narratives that highlight the power and influence of the movement. This article compares two of the Asian Youth movements that operated in the late 1970 s and early 1980 s to explore the importance of investigating localised settings when researching the history and impact of the anti-racist movement as a whole. Oral histories and documents produced by the Asian Youth Movements are used to reflect and understand how the organisations operated and developed differently, highlighting the influence of specific urban environments which affected local migratory experiences and therefore the makeup and operations of the movements themselves.
\end{abstract}

Anti-racist movements develop and maintain their energy through the establishment of local, grass root networks. To date research on the anti-racist movement in Britain has focused on political events and mobilisations which unfolded on the national level. ${ }^{1}$ This article compares two groups which formed part of the Asian Youth Movement in Britain, which were active in the late 1970 and early 1980 s. The Asian youth Movements of the 1970 s and 1980 s in Britain sought to struggle against State and institutional racism and for basic civil rights for South Asian migrants who had come to Britain during the post war period. In pursuit of these objectives they were part of a wider anti- racist movement. These included both independent and State sponsored organisations including the Institute of Race Relations; The Campaign against Racism and Fascism; The Race Today Collective; Black People's Alliance; The Anti Nazi League; and many more which operated as national bodies. At the same time, however, the Asian Youth Movement (AYM) was also embedded in specific localities and gained their influence through their involvement in grassroots campaigns and activities. This essay will explore the local differences between the Asian Youth Movements in two northern cities: Bradford and Manchester, in order to consider how the cities themselves and the characteristics of the organisations in each town affected the development and actions of these local anti-racist organisations and the way they are remembered.

Acknowledging the local histories of these movements is not to undermine the national narrative of the anti-racist movement that developed in Britain during the late 1970 s and early 1980s, but to understand the complexity of this movement that incorporated a wide range of groups and individuals who believed in, and struggled for, equal rights for those living in Britain.

\section{Anti-racist movement history in Britain}

The anti-racist movement as a whole developed to take up issues of discrimination that Commonwealth migrants increasingly faced after the economic depression of the 1970s led to the scape-goating of Black communities as the root cause of the problem. Racism impacted on all areas of life: Black school children were forced into immigrant classes and into schools out of their communities after the policy of bussing Black children to school was introduced in the '6os to prevent too many black children being in one class; racism was experienced by Black families trying to find decent housing as well as on the street as the phenomenon of 'paki-bashing' took hold and racist policing led to the harassment of young men of African and Asian origin in particular. The State entrenched the concept of Black people as the problem by instituting ever more stringent immigration laws through 
the 1970 s that eventually, in 1981, took away the right to any child born in Britain from living here. Anti-racists began to organise both local grass roots campaigns through the 7os to take up issues for local communities as well as national campaigns against the immigration laws.

Sivanandan's From Resistance to Rebellion emphasises this quality of anti-racist organisations in the 1970 s and early 1980 s to form and function as a result of specific circumstances, such as a fascist attack or police harassment. He highlights this phenomenon noting a wide variety of organisations that sprang up across the country such as the Southall Youth Movement, People's Unite, Bradford Blacks and the Asian Youth Movement in Bradford. ${ }^{2}$ Sivanandan's article explores the development of these local organisations as a national phenomenon and also cites their place within the longer history of Black resistance in Britain from the mid twentieth century making links between anticolonial struggles of the mid twentieth century and anti-racist struggles of the late twentieth century. ${ }^{3}$ The organisations that Sivanandan refers to however, were often extremely different in the size, age, social and cultural background of their members and this gave rise to different ways of organising. This is not to suggest that they did not act nationally in the sense of organising national protests and liasing across cities and communities, which they did, but the specific migratory and industrial histories of the cities and districts in which these organisations emerged was also influential on the ways in which they operated. ${ }^{4}$

Recently, in the US, an increasing amount of research on the Civil Rights Movement has been directed towards looking at local organisation in order to present a more in-depth account of the Civil Rights Movement, recognising its contradictory currents, for example violent and non-violent struggles, legal and illegal action, and their influences in specific regions. ${ }^{5}$

Through my research on the Asian Youth Movements it is clear that when individuals speak about their involvement in the anti-racist movement they do so primarily in terms of their localized experience, even down to describing the geographies of streets where events occurred. The two booklets entitled Campaign for Racism and Fascism's are documentation of the local struggles in Southall and Newham that provide an understanding of a local community and its specific history. ${ }^{6}$ The particular experience of Asian youth in the north of England however has not been explored and there has been little consideration of the impact of specific city environments on the development of these youth movements. ${ }^{7}$ The existence of documentation on London based organisations rather than those in the north has meant that these London based organisations have stood for Asian Youth Movements in Britain as a whole. ${ }^{8}$ It should also be noted that throughout this essay I talk of the Asian Youth Movements rather than movement. I have discussed them in the plural in order to recognise that each city group was in fact a separate organisation. While they were part of a wider anti-racist movement and their actions were part of a wider series of actions and impulses towards struggling against racism in Britian during the 1970 s and 1980s, they chose to use the term 'movement 'in the name of their organisations and it is organisationally that I refer to them in the plural.

\section{The City, the Grassroots and the 'structure of feeling'}

Castells' influential text on the City and the Grassroots argues for the importance of investigating space and place in a social movement organisation. He also asserts the crucial role that social movements play in the development and identity of the city: 'the process of production of the cities by societies is most evident in the case of social revolt and spatial innovation. ${ }^{\prime 9}$ Castells' definition of an urban social movement as campaigning for improved collective consumption; struggling for a community culture as well as for political self-determination reflects the role that the Asian Youth Movements in Britain of the 1970 and 1980 s were involved with. Investigating localised experiences enables us to understand why some movements were more successful, lasted longer and had a more lasting impact on the communities and cities in which they operated. The focus on the local also enables us to understand these cities as complex geographic and social spaces that impinge on what Williams described as the 'structure of feeling' of a society. 
The article will make use of archival materials produced by the youth movements as well as fourteen in depth interviews with key members of the Asian Youth Movements in Manchester and Bradford. They were not collected as a representative sample but were collected from individuals who through the establishment of trust were prepared to talk about a period of history that they wished to preserve but wanted to share with a researcher who they felt was sympathetic to their past and what they were trying to achieve. As an individual who was involved in anti-racist campaigns in Manchester during the late 1980 s and early 1990s, I met many of the individuals as a fellow campaigner. It was these former members who shared their knowledge of the movement with me before I began the interviews and made suggestions as to who they thought would be good individuals to interview. There were some individuals who also for personal reasons excluded themselves from the sharing of their own histories. It is therefore not possible to see these interviews as a representative sample. For this reason the style of interview was qualitative and in-depth to explore the past and the movement in as reflective a way as possible. My approach has an affinity with Brian Alleyne's investigation of the New Beacon Books' circle in terms of his adoption of a reflective and critical humanist framework to investigate the circle and their participants. ${ }^{10}$

I will consider the migratory experiences of the cities, the geographies and industries that were embedded in them and explore how this impacted on the membership, size and organisational practises of the movements in both Manchester and Bradford. In exploring Manchester and Bradford, we are able to highlight the differences between two northern towns - a geographical area that is often lumped together as northern. In writing about the differences between the youth movements, the suggestion is not that one community was operating in a more successful way than the other, but simply to acknowledge that local geographies and the specificities of a community or communities change quite dramatically what can be done.

\section{Bradford}

\section{Migratory experience and the development of the Bradford Asian Community}

Northern towns and cities in Yorkshire and Lancashire such as Bradford saw the migration of a large number of migrants primarily from rural areas of Azad Kashmir and Northern Punjab.11 Bradford had the highest concentrations of Asians in comparison to any other northern town. In 1964 there were approximately 12,000 Pakistanis in Bradford. By 1970 the approximate figure was 21,000. As Badr Dahya notes these migrants were mainly employed in the wool and engineering industries. Of the ten members of Bradford Asian Youth Movement whom I interviewed, all of their parents were employed in the mills and factories of Bradford although many of them indicated that their parents quickly moved on after saving enough money to establish their own businesses:

'my father was a business man before he left Pakistan, and when he came here he started working in a foundry in the steel works. But he was there for a very short time, because he quickly got into his own business. ${ }^{12}$

'My father began working in England in a lighting factory as his first job but he very quickly established his own tailoring business. ${ }^{13}$

These key activists shared the migratory experience of the majority of Pakistanis in Bradford, not only in terms of the kind of work that their parents were involved with but also in terms of the de-classing experience which many experienced. The parents of these young people were mainly factory workers, especially mill workers, but also included parents or relatives who were bus drivers and shopkeepers. Their parents however were not all labourers in the sub-continent, so a significant proportion of the group included aspiring families and individuals. Two of the key members were grammar school boys. This de-classing experience and the desire to better themselves was an experience that Bradford Asians shared with those in other towns and cities. 
This experience can be seen as a contributory factor in why young people organised themselves and their need to establish a sense of self worth. As Dahya notes:

'the fact that the politically dominant group of the host society judges the immigrants as belonging at the bottom of the class structure in Britain, is not a valid reason for a sociologist to assume that the immigrants and the native proletariat share a single scale in values and preferences ${ }^{144}$

\section{As Anwar Qadir commented:}

'it was almost a magnet pulling us all together, ...'cos we were all coming from our... own experiences, but we were all coming together because we cared, because we were, in a way, a generation who were expected to go in and do all the jobs where our parents had left off - but we were a generation that was saying we're not going to be doing that. Life has a lot more to offer to us than working in the foundries and the mills, and driving the buses and cleaning hospitals, so we were a generation that was saying 'no', we were not the generation that was thinking about, well we've got family back home and we need to look after them etc., etc. Because our parents had done that. We were a generation that was saying 'no we won't take it lying down, no we won't do these jobs, yes we will want to have white collar jobs, yes, yes we want to be in management, yes we want to be in your colleges and teach, yes, we want to be in your schools and teach, and your banks etc etc. ${ }^{\prime 15}$

Dahya has noted how, by 1970 with a population of 21,000 , there were 260 immigrant owned and operated businesses in Bradford. ${ }^{16}$ The majority of these shops and businesses were in Mannigham. The development of a significant number of shops and businesses not only operated to enable the economic betterment of the community but also acted as a way of sharing culture and values, which could then be passed from one generation to the next. It is clear that this small but enterprising community stuck together to establish a space in Manningham that enabled the South Asian Migrants to support each other and survive, despite an environment where racism was endemic.

\section{Social and Political influences}

The overriding reasons for the creation of the Asian Youth Movement in Bradford was both the general level of racism and the strength of the fascist presence in Bradford in the 1970s. Institutional racism had created the de-classing experience that I have described above, and street racism created situations of violence and aggression which made it impossible to ignore. Many of the young people who joined the movement experienced racism in all areas of their lives and commented on these experiences and their impact:

'My first real political consciousness occurred probably before I was seven, when there was a huge demonstration in Bradford, organised by the Muslim community about a..so-called accidental shooting of a Pakistani boy that pulled out a toy gun and was shot.... I was a spectator on the side streets... But then growing up as an eight year old in Bradford, some interesting things happened to you ... the first thing that we faced was bussing, of course, and that was the education policy in the kind of late 6os and early 70 s to actually disperse Muslim communities ... but it was really the Black or Asian community at the time. So I had a seven mile journey as a four and a half year old to school, which is unheard of today, and you could go up quite a famous road in Bradford, Lumb Lane and could find something like 15 buses that would bus literally hundreds of Asian children to all parts of Bradford....17

Norrzaman's elder brother Jani, recalls incidents of racism in school:

'I was about nine years old... there was one particular guy whose name was James - was the sort of school bully basically - who decided to call me a 'monkey'. So first of all he started calling me a 'monkey' and then he started calling me a 'Paki' and then a 'blackie'. And he being a bully, he'd sort of managed to get other school children, you know, to call me names and that culminated in a fight eventually and it was in fact a student teacher that stopped the fight and you know he'd obviously had problems with this bully as well because his remark to me was ...'next time I should hit him harder '. 
But there was nothing said about it in terms of school, nobody suggested that he shouldn't be saying these sort of things... of a racial nature'. ${ }^{18}$

Anwar Qadir recalls how a skinhead's attack on his brother made him organise:

'I was in the youth club, one night my brother got beaten up by a group of skin heads, now until that point we had nothing to do with skinheads... my brother described what they looked like and ...we recognised some of the people that he was talking about cos we had seen them on the streets,... it wasn't "we're Asians and we're being exploited" and that, there was none of that, it was 'right well these skinheads are about to have a go at us Asians right, and we're going to teach them a lesson'... that was maybe the beginning of the journey...'

For Tariq Mehmood, the playground in school was itself a violent place:

'in the playground... we were forced to form sort of elementary organisations....without a structure of anything like that... if we were on buses it wasn't that you could just walk freely and on our playground it was very violent.. and in our classrooms I still remember very clearly I learnt to speak English and I was still learning English... I said to the teacher, I could speak English now, I could read it... why do I still have to remain in the stream learning English? ... I had to get my uncle to go into school and say look he speaks English why does he have to learn English again?'

It is clear from the memories cited above that racism galvanised and forced the youth to organise, often without conscious political understanding, but the importance of organising themselves was made clear to them in their daily lives. These experiences were not unique to Bradford but were part of the Bradford experience and there was a significant group within the local population that was unhappy about the presence of a growing South Asian community. In local political circles, as Dave Stark, a local trade unionist and trade union campaigner, mentions, 'Race was always on the agenda in Bradford from the early 1960 s onwards. And there were disputes between Councillors, between political parties about immigration and about race.' The town saw the establishment of the Yorkshire Campaign against Immigration in 1969 which eventually became the National Campaign against Immigration and then the National Front (NF). This indicates the centrality to Bradford in the debate and fostering of racist immigration policies and attitudes.

\section{The 1976 fascist march}

The difference between the theoretical debates and the practical realities of life were brought home for Tariq and others when the fascists decided to March through the area of Manningham in 1976. The strategy of marching through black areas by the NF was a deliberate attempt by fascists to declare the streets as theirs, to mark black people as not belonging to Britain and target them as the cause of the 1970 economic crisis. The NF believed that street marches and street action would enable them to 'march and grow' through the media profile that they would initiate. ${ }^{19}$ A number of former members comment on fascist activity as a clear impetus to the development of an Asian Youth Movement:

'I think there was a feeling that there was a need for an organisation to come together to fight against the injustices that young Asians, the young Asian community were facing at the time. We'd picked up on the activity of the National Front and how they were mobilising and wanting to essentially repatriate the Asian community,... all this talk about, the Asian community stealing our jobs, stealing our homes, stealing our women, that kind of stuff... and in fact, you know, in 1976 the National Front decided to hold a meeting in a school in the heart of where we lived and... that was my first recollection of a riot in Bradford basically, ... where police cars were turned over, paint was thrown at them, and being chased by police on horseback, And that was basically because they'd allowed the National Front, I think it was Martin Webster at the time, to come to Bradford and hold a meeting in a school in Manningham. So that was, I suppose, the first real campaign that I can recollect of any kind which was about defending our homes and our community basically, because that where 
most of us lived. I lived on Lumb Lane. ${ }^{20}$

In reflecting on the formation of the AYM Bradford, a number of key members talked about the 1976 fascist march and meeting that the NF attempted to stage in Manningham. Manningham was a predominantly working class community with relatively cheap terraced housing, surrounded by mills and factories and by the mid 1970 saw the settlement of a sizeable Asian community. Most of the members from Bradford had attended school in the area and had defended each other at school from racism. This meant that many had close bonds with each other from a young age. A large proportion of the activists whom I interviewed were from Mannigham. Out of 14 key activists in Bradford, ten lived in Bradford 8, the Manningham area, where they had defended their community against the fascists. ${ }^{21}$ Two were from Bradford 3 where the Indian Workers Association (IWA) were influential and two were from Bradford 7. The concentration of individuals from one specific community made a significant impact on the way in which the AYM were able to organise, the impact they had on their community and the way in which the community identified with them. The Asian Youth Movement, (Bradford)'s first office was also on Lumb Lane, an important thoroughfare in Manningham and it was an office which they established independently of any other community organisation. The close cultural and community ties, the experience of going to school together and defending each other all affected the strength and nature of Bradford AYM and its impact.

The key concern to defend their community can be seen by the differing positions taken by the Trades Council and the youth during the anti-fascist march and protests on 24 April 1976. As Race Today commented:

'For the organisers, Bradford Trades Council, the issue was mobilisation of massive opposition to the Front. The Black community, on the other hand, incensed at the fascist invasion, were concerned with defending their home territory. As the counter demo moved out of the immigrant area, many Black demonstrators stayed put. Those Blacks who continued with the march into the city centre soon returned when they heard that violence had broken out at home. ${ }^{\prime 22}$

Tariq Mehmood's recollections emphasise the feelings that the young people had at the time:

'We saw them [the fascists] as coming to wipe us out, kick us out of our streets... or start the process and we weren't going to have it and there was a very big march against the fascists... . and the march, the big anti-fascist march led by sort of the leaders of that time ended in the city centre. Now we lived in Manningham, or lots of us lived in Manningham, we marched to Manningham... broke through police lines, ran sneaked, because Manningham was ours and we had to protect it .... it was there that we really started thinking that we got to get our own house in order, we can't have this, we can't leave our future in the hands of people like... what we hated were the community leaders or the Labour Party types who would take control of our future.... We can fight and we can win...I think that there would have been the seeds of where the Asian Youth Movements began to be formed."

AYM (Bradford) was also inspired by the direct action taken by Asian Youth in Southall after the murder of Gurdip Singh Chaggar in 1976 by fascists. Chaggar's death on a main thoroughfare in Southall was seen as a direct attack on the south Asian community. While the elders and the Indian Workers Association (Southall) responded by holding a public meeting and demanding an enquiry. The youth however were not prepared to wait and marched on the police station demanding justice. When two young men were arrested as a consequence, the need to organise themselves was immediately apparent and the following day the Southall Youth Movement (SYM) was formed. ${ }^{23}$ Southall Youth Movement first acted primarily as a defence organisation, as Balraj Purwal recalls:

'we went round kind of giving support.... trying to make these areas that were no-go open for all.. and to make Southall a no-go zone for racists and that was pretty effective, just so many people, you know. ${ }^{24}$ 
in contrast, while coming out of the same experience of needing to defend their community against the fascists, was never simply a self-defence force, but a well organised group that campaigned and struggled for black rights in terms of housing, education, immigration and wished to offer a thoughtful political understanding of national and global politics. They were only integrated into the state's youth and community structures in the early 1980 s in contrast to SYM.

\section{The left in Bradford}

Socialist and trade union organisations as well as the Indian Workers Association (Bradford) - an organisation that was not simply a migrant welfare organisation, but one that was deeply integrated with the trade union movement in the UK and with the Communist Party of India (ML) were also influential on the development of the youth movements. The nature of the IWA in Bradford contrasted with that of Southall. While IWA (Southall) was much more pro-establishment, and had a history of supporting the Labour Party as highlighted by DeWitt, ${ }^{23}$ the IWA in Bradford was linked more closely with IWA (Birmingham) under Jagmohan Joshi, an organistion that had condemned the Labour Party's immigration strategies in the 1960 s and had taken a much more militant position with regards to the use of strike action. IWA (Bradford) like IWA (Birmingham) was also clearly supportive of militant activity against fascists as Dave Stark:

'when the National Front began to move into Bradford, they held meetings, they held marches, it would have been a mix of trade unionists including members of IWA, Asian, black and white students,....it was always direct action, it was confronting them on the streets and occupying the meetings in Bradford..... the police came in as usual, arrested people, threw people out, that was the normal tactic, it was direct action... I suppose there was a tacit and direct agreement that you should confront the National Front and don't just talk about it. They should be confronted... any time they appeared. ${ }^{26}$

The IWA in Bradford clearly provided guidance for the youth as they began to organise. They first encouraged the formation of the Indian Progressive Youth Association and also provided an example of an organisation that was involved in both anti-racist politics as well as trade union and socialist politics. The secretary of the IWA, Jagtor Singh Sahota, was an active member of the Transport and General Workers Union (TGWU), eventually becoming the regional secretary in 1979. Sahota, like the AYMs recognised the trade unions as an essential ally while also being aware of their racism. ${ }^{27}$ The IWA's influence is also clear in Tariq Mehmood's novel hand on the Sun where the young man Jalib clearly values the advice of the old comrade Dalair Singh: 'we must make our history into a weapon. We must learn from each defeat'. ${ }^{28}$

Asian Youth Movement (Bradford), unlike Southall also had three key members that were formerly members of white left, Trotskyite organisations before developing the AYM. One worked in Militant, another in the Workers Revolutionary Party and a third in International Socialists. This early influence of socialist organisation had a profound influence on the Bradford Asian Youth Movement and the way in which it developed and ran itself as an organisation. Tariq Mehmood recalls how he joined International Socialists, which he felt a lot of affinity towards as an organisation:

'because they seemed to have a lot more Asian people with them. They were coming from London. I think there was a group called Chingari or something, which Sunu Engineer and some of the others produced in Urdu and Hindi and different languages and it was at that time that I began to think that I could work with them. But I was really really angry with them as well because once they asked me to speak on racism because I must have been... one of the few non-whites in Bradford at that time. I had no idea, I just had no idea how to articulate what racism was, I knew how to fight it because I didn't have a choice, I couldn't articulate the theoretical concept that it's a device used which is what the SWP wanted me to say you know... it's something used to divide black workers and white workers... and I was also beginning to be unhappy with many other different concepts and some of these were theoretical things. I just couldn't get answers from the theoreticians within the Socialist Workers. ...(IS) I wanted a Socialist world because I felt, 'that's our only future' and I understood by 
socialism things different to my white colleagues. And some of those things were that could we build socialism in one country? For me the ideas of socialism means that somebody didn't have to leave their mother and go thousands of miles away, to have electricity, to have water, to go to school near where you lived and for all of you to have work, but we had all that in England.. with struggles..and I was thinking back home in my village and I said no, my concept would be to get what we've got here and it didn't make sense to say no, it has to be global...'.

Two of the three organisers whom I interviewed that were members of left organisations before joining AYM related tales of being used as the token Asian and their frustration with their organisation's privileging of class politics above issues of race. ${ }^{29}$ The experience of organising in a left organisation, was not only influential in terms of propelling these young men into action because of the frustration that they felt by working in an organisation which was not representing or meeting the needs of their own people but also in terms of learning the value of discipline. More than one member talked of how they operated almost like a party, and how individuals had to apply for full membership.

'the AYMs recruited members I think it was a bit like a Communist organisation in the early days, they had to be nominated. You couldn't just turn up and say 'I want to join', someone had to propose you, you had to be on a probationary period, the Executive Committee had to discuss your membership, your membership would then have to be approved after your probationary period was over, if you misbehaved or didn't stand up to the aims and objectives, you were warned and brought in front of a disciplinary committee and you were disciplined and thrown out if need be. And you know we were building a cadre based body and probably at our height, we might have had a couple of hundred members'.30

The movement also had very firm practises to avoid any activity that would bring the organisation into disrepute. For example, they were not allowed to drink before being involved in AYM activity and they were not allowed to date girls from families who the AYM were campaigning for, in immigration campaigns or any other. This was very different to Southall, which was almost entirely based around a street politics of self defence and where there does not appear to have been the formal discipline which you might find in a party, There was, however, extreme loyalty between members in Southall as was appropriate for an organisation that did sometimes worked outside of the law.

The need for a left organisation which was 'black' led could not be fulfilled by the IWA in Bradford because the community was mainly Pakistani and Kashmiri. As Jani Rashid commented: ' we were going around knocking on people's doors and asking them to join the Indian Progressive Youth Association... the feedback we were getting..was...

'well, you know, we're not Indian, we're Pakistanis', and of course we used the word Indian because it was the Indian sub-continent... but the people that we were trying to recruit felt alienated because we used the word Indian. So we very quickly, within a year I think.... changed it from Indian Progressive Youth Association to the Asian Youth Movement. ${ }^{\prime 1}$

The predominantly Azad Kashmiri and Pakistani population did not have workers' organisation that could support the development of a youth organisation.

It is clear that both fascist activity, the experience of trade union and socialist activism in Bradford, the presence of the IWA as well as what young people saw as the lack of effective direct action by large sections of trade unionists and left organisations, along with the lack of a migrant workers organisations which truly represented the population, made these young Asians believe that they had to organise themselves.

\section{A Second Generation Organisation}

The sense of home being in Britain, on the streets in which they lived rather than in the villages of Kashmir or Indo-Pak Punjab, which were becoming distant memories was also important for 
the development of the youth movement in Bradford. Rather than being aware of the differences between them in terms of the divides between India, Pakistan and Bangladesh, they searched out their commonalities. Having said this the migratory patterns pertaining to Bradford meant that the organisation was heavily Punjabi in its cultural and linguistic identity because of the number of members from both India and Pakistan that spoke, (what were regarded at the time) as various forms of Punjabi. The organisation however, was open minded and not chauvinistic in its cultural or religious outlook and included Gujerati members as well as individuals from Malaysia. The movement had members from all the major faiths in South Asia.

A number of members commented on this feeling of being here to stay, As Tariq Mehmood mentions:

I/ we were becoming conscious of the fact that you know whatever that was going on has become our life, I wasn't going back that easily... you know mother had become a bit of a faded memory...I wasn't able to write much to her anyway... I knew she couldn't read English so it was becoming difficult for me to write in the little bit of Urdu that I wrote... we were meeting lots of people and women were coming in as well... so it was a bit more of a family life developing at the time... ${ }^{132}$

The arrival of women into the migrant community was an important shift in the way the community thought about itself. During the early 1960 s men outnumbered women 40 to $1^{33}$. Many of the key members of the youth movements came to Bradford in the 1960 s when the number of families began to increase but the Asian population was still predominantly male. Many of the fathers of these young people had come to work first, as Shanaaz Ali recalls:

'My father came out in 1963, just after I was born... [he] came and then, I think he couldn't live here. I think he felt that because he was ill and various other things... He just missed his family. So he then decided to call us over, despite his friends and people, other men from our area saying, 'you're mad. We're all going to work for a few years and go back'.

Those who did bring children when they first came, brought their sons so that they would eventually be able to contribute to the family income through work and send money back home as soon as they came of age.

The make up of AYM (Bradford) reflects the influence of the early phase of migrant workers who brought their sons or nephews to Britain to work as well as the development of an emerging family life with the establishment of women and young children in the community. Many of the members who I interviewed came to Britain in the mid 1960s when the number of families would have been extremely small. The predominance of young men in the community and of course the difficulties of those women and girls who were present from these traditionally rural communities to gain access to independence that would enable them to participate in political activity, meant that Bradford AYM began its development as entirely male although later on there were women involved, but always only in small numbers.

'As Jani Rashid commented: 'We didn't have many Asian Women in the organisation, my sister was a member, she didn't always come to meetings cos we were a largely male group and we did increase our membership to more than just my sister later on,... but I have to say in terms of membership it was very very limited in terms of women... there were accusations from ... all sorts of groups that we were a sexist organisation... but I didn't feel it was... most young Asian women were still sort of... kept at home by their parents, and you know to be exposed to the likes of young men from the Asian Youth Movement wasn't the right thing to do...'

In character it is therefore not surprising that there were elements of machoism present in the behaviour of the young men and in their organisation. This was not simply a form of masculinity 
town of Bradford. ${ }^{34}$ The angry young man image that was often seen in leaflets and posters of that time characterises Asian Youth Movement (Bradford), was not only influenced by traditional forms of masculinity present within the migrant community but also by traditional forms of northern British masculinity that were present in northern mill towns, where young men had historically gained their place and purpose in society through hard physical labour. ${ }^{35}$

\section{Geographies and spaces}

Another key influence on AYM (Bradford) was the library. The central library in Bradford had a cafe and it became a focus for ad hoc meetings and educational discussions. It was accessible for young people all over the city and walking distance from Manningham. It was a public space that enabled the youth quite profoundly. Tariq Mehmood, who was estranged from his family ,practically lived in the library and he associates this with his growing political awareness.

'... I had the library to stay in, so I had the advantage over them in that sense. They were grounded in school and stuff... But I'd be in the library as soon as it opened. I'd be there until it closed. ... I just read a lot, I had nothing else to do during the day... didn't have family, didn't have a home, I just read as much as I could. I began to understand that the world I lived in was really fundamentally unfair. I began to understand that this country was rich because we were poor and I also began to understand that we were here because they were there and I really believed that.'

Another member, Gurnam Singh talks about the meetings and discussions that took place there:

'We used to kind of go in the library cafe when it opened in the morning, ... We didn't have much money so we'd all buy a cup of tea ... just to prove that we were bona fide. And we'd do crosswords; the Guardian crossword and things like that... we used to share what we were reading and then it would get into disputes about certain politics, and I would say, 'Go and get the book'. And so the library was like our kind of reference. It was there and we were talking and ... I can remember reading Capital, Marx's Capital, and discussing that. And talking about Gramsci and all these other people. And this was around the age of 16 to 17, and becoming politicised.

Sometimes I'd go to the library in the evenings as well as after school. Or actually slam from school, miss classes and end up in the library. Which I mean, I think back to that, and I think that was something to do with developing a critical education. ${ }^{136}$

The library did not act as an educator independently. The activities of the left in Bradford and their interaction with South Asian youth was important to the direction that AYM (Bradford) took. Near the library, the Fourth Idea Bookshop also provided a space of inspiration:

'The fourth idea bookshop was a bookshop plus with some sort of printing facility in there, and an old comrade... he's departed now, called Rubin Goldberg who used to work there. I think he was part of the International Marxist group of which Tariq Ali was a member as well And that's the place which had really provided us with a lot of support, ideological support, support with ideas and sometimes we would debate in the library and up at the fourth idea book shop, borrow books from there, read books...'37

Geographies and social and political influences worked together to influence the development and nature of the Asian Youth Movement (Bradford). The forms of self education that took place in the public space of the library and the Fourth Idea Bookshop, the lessons of discipline and socialist perspectives learnt from the white left, meant that the macho culture of street battles and street patrols were tempered in the Asian Youth Movement (Bradford). They also saw the value in communicating their ideas to their public by producing a magazine that represented their thoughts and ideas, just as left groups did. Through Kala Tara in particular they gave their work and campaigning longevity and formalism. The magazine outlined their aims and objectives 
'here to stay, here to fight' and their ideological perspectives: to struggle against 'all forms of discrimination based on race, colour, sex, religion etc ... and to promote the cause of equal rights'; to support national liberation movements and encourage cooperation between different nationalities in the Indian subcontinent, and recognised that the only real force in British society capable of fighting racism was a united workers 'movement.'

The strength of Manningham as a community, through the specific migratory experience of Asians in Bradford, the influence of the political climate in general and the existance of the IWA in an area where Pakistanis and Kashmiris dominated; the experience of working in the white left and the discipline of communist organising that some of the young people had learnt before establishing the AYM; the spaces such as the forth idea book shop and Bradford Library and its cafe in a central location close to Mannigham gave the Asian Youth Movement in Bradford the ability to organise effectively and a legitimacy because of their links with the main community of Manningham. All these factors influenced the longevity and power of $A Y M(B)$ to organise. At its height $A Y M(B)$ had about 200 paid up members working and organising, along with hundreds of supporters, running successful anti-deportation campaigns, campaigns against racism of the police, racism in education and struggling against street racism. Its size and influence was far larger than the Asian Youth Movement (Manchester) The size and influence of the $A Y M(B)$ meant that they were able to sustain themselves as an organisation right until 1986/7, although the organisation changed in its nature as it grew older, establishing itself more in its later years as as a community centre funding youth organisation than as an agitating and campaigning body.

\section{Manchester}

In contrast to Bradford, larger cities such as London and Manchester encouraged a wider range of migrants including students, professionals and labouring classes. These cities also saw a wider diversity in the cultural and ethnic origin of migrants, although large numbers of migrants still tended to settle where they had familial or community contacts and support. The cities themselves, the institutions and businesses that migrants established, as well as the historic institutions such as libraries and universities that were already established also impacted on how individual AYMs operated and are remembered.

\section{Migration to Manchester}

The history of Manchester is significantly different to the history of Bradford which is smaller and defined almost entirely by its textile industry. Manchester by contrast, while holding an enormously significant role in the history of the textile industry, also has a long history as a commercial and metropolitan centre. This has been recognised as a significant factor in its 'structure of feeling' and it is certainly the case that it has influenced the kind of migration that has taken place to the city. In 1971, the number of Manchester residents born in India was 2879 ( $0.5 \%$ of Manchester residents) and the number of those born in Pakistan was 3388 ( $0.6 \%$ of Manchester residents). By 1981 those born in India had actually decreased for Indians to 2742 ( $0.6 \%$ of Manchester population) and increased for Pakistanis to 4975 (1.1\% of Manchester residents). The number of Bangladeshis appeared for the first time as 607 (0.1\%of Manchester residents). The 1981 figures do not include those born in Britain so to some extent they are an underestimate of the actual population. ${ }^{38}$ In spite of this, it is clear that the Asian community in Manchester was smaller both in proportion to the entire population as well as in actual size to that of Bradford. The mix of immigrants from South Asia to Manchester was also much wider. Manchester's metropolitan status and size attracted individuals from India and Pakistan's professional classes as well as those from rural backgrounds. ${ }^{39}$ There were still specific areas such as Cheetham Hill, Longsight and Whalley Range to which South Asian migrants settled, but bearing in mind the size of Manchester and the scattering of South Asians across various localities, it is inevitable that migrant organisations would find it much harder to have a significant influence both within migrant communities as well as within the local politics of Manchester as a whole. It is also significant that Werbner's study of Pakistanis from the 1970 and 1980 s was not drawn from families employed within factories but from a group of families operating as entrepreneurs. $4^{\circ}$ Manchester's 
identity as a commercial city may have impacted on individual choices when choosing a location to settle and the pattern of chain migration which was strong in Bradford as well as smaller towns in Greater Manchester such as Oldham ${ }^{4^{1}}$ was less evident in Manchester and this made the community more fluid.

\title{
Social and Political influences on the formation of AYM (Manchester)
}

Unlike Bradford or Southall, where a specific attack on the Asian community galvanised individuals together, the Asian Youth Movement in Manchester did not develop in such a spontaneous way. The impetus for political action was different. From the start they were far more implicated and involved in already established local community structures. This is how one Manchester member, Nilofer Shaikh described the influences on her just before she helped establish the AYM (Manchester).

\begin{abstract}
'there were different kinds of influences and there were other community workers, Asian community workers, older community workers who formed a group called the Asian Workers Association..., and I joined that ... you know it was more around how do we support each other as Asian workers in our work with the Asian community; and I remember even helping to organise conferences,... people were using different ways to combat or tackle racism, you know, one was from the level of cultural sort of things to a really political level.'
\end{abstract}

What this reflection highlights is that members of an AYM (Manchester) were not necessarily completely disenfranchised. They were employed to work in their communities in areas such as community development, but they did also experience racism as black workers and as students and wished to make links with others that experienced discrimination and speak up against it. Of the eight initial members of an AYM (Manchester) that I learned about, two were overseas students and three were students with families living in Britain. Being a student is primarily an activity which is associated with and enables self-betterment. The three remaining members were working people, one of whom was a surgeon. Only one of the eight initial key AYM (Manchester) members had been to school in Manchester after migrating to Britain at the age of 13. Apart from the three that were registered students, the others were all working by the time they set up the AYM, one in a women's refuge, another in the WEA and a third as an electronic engineer. In terms of the membership therefore, AYM (Manchester ) had more formal education, included members that were substantially older and more mature and included a larger proportion of aspiring individuals. They were individuals who did not have the same roots in Manchester as the young people in Bradford, although they were extremely committed to struggling for social justice and in many senses they were not the second generation with parents working in Britain in quite the same way as Bradford. All these qualities impacted on how they mobilised and what they were able to achieve.

\section{The Left in Manchester}

While the British left in Bradford had a significant impact on an AYM (Bradford), the Asian Youth Movement (Manchester) although still influenced by left politics was more significantly influenced by left organisations in Pakistan and Bangladesh. The links between this international influence was different to Bradford's influence from the IWAs, because the IWAs were migrant organisations set up by the first generation migrants with influence from the various Indian Communist Parties. The influence for Manchester was more direct since two of its members had been involved in communist organisations in Pakistan and Bangladesh. Mohsin Zulfiqar had been involved with the National Student Federation in Pakistan as well as with the National Awami Party during the late 1960s, coming to Britain in 1971. Qumral Kabir, from Bangladesh had also been involved with a communist organisation in Bangladesh and with the movement for Bangladeshi independence before arriving in Britain as a student in 1971. Both individuals continued to organise within the left in Britain after their arrival here, but the influence of Trotskyism in the British left meant both were quick to move outside of the British left and begin to involve themselves in anti-racist and anti-imperialist struggles, including the Imperial Typewriters Strike in Leicester and the Overseas Students' Strike. The crippling rise in fees for overseas students in the 1970s impacted directly on these members and their friends 
and the Overseas students strike employed a number of direct actions such as sit ins to protest at the draconian increases that were imposed in universities across Britain including Manchester and Loughborough where these members were situated.

\section{Geographies and spaces}

AYM (Manchester) also operated in South Central Manchester- the areas of Longsight, Rusholme, Ardwick and Old Trafford - as well as in the Cheetham Hill area of North Manchester. The areas of Longsight, Rusholme, Ardwick and Old Trafford in particular lie very close to the city centre and are dominated by the university with its large and transient student population and regionally significant hospitals such as the MRI, St Mary's and Christie's Hospital. These spaces are ones that attract a wide variety of people with very different life experiences. Despite these large institutions and public spaces there wasn't, however, a central space as in Bradford library for young people to congregate. Longsight Library, which was used for meetings did not have a cafe and the spaces such as youth centres that the AYM did use to mobilise young people were spaces that were essentially there to organise young people, not spaces where they organised themselves.

The mix of individuals and experiences and the less unitary sense of place made the AYM (Manchester) less focused on a specific community although they had some community links in Longsight and Cheetham Hill, which they used to mobilise for specific immigration campaigns, but they did not as individuals all belong to those communities in quite the same way as Bradford did. The lack of a unitary place like Mannignham and its environs meant for example that while the AYM (Bradford) organised self-defence patrols in their communities and as one member said ' we were willing to break the law' and 'we wanted a mass base outside of the state', (in this sense they had an affiliation to Southall and did in fact have contact with them, which Manchester did not), Manchester was less involved in such self defence activities and rather than organising their own self-defence groups joined a telephone tree organised by South Manchester Law Centre to support individuals suffering racist attacks. ${ }^{43}$ AYM (Manchester) did however recognise the right to self-defence and organised meetings in support of a mosque that was being attacked and were very supportive of the kind of activities that Bradford and Southall were involved with.

In temperament Manchester and Bradford organisations were different-Manchester, as one member from Bradford mentioned was 'more mature' and less angry. Some of the members were older, they were from a more middle class and intellectual background and they had Marxist Leninist training in their home countries. They understood how political organisations worked, which members from Bradford only learnt through the experience of being involved with the white left and liasing with them. The angry young man image that is often associated with the youth movements, which very much applies to Bradford, does not characterise Manchester.

\section{Women and the AYM (Manchester)}

Apart from the middle class, intellectual and anti-imperialist experience of the Asian Youth Movement (Manchester), two key members of the movement were also women. Manchester as a much bigger, more affluent urban environment, attracting a more diverse group of people had women members from the subcontinent who came from educated middle class, urban families. This meant that as Manchester developed as an organisation, especially with the political experience that a couple of members brought with them, they were able to organise a women's wing to increase the involvement of women. They were the only AYM in the country that were able to do this, and although the women's wing was small, it did enable Manchester to not only mobilise women generally but also to offer women that were the focus of many immigration and anti-deportation cases, support from other women. Manchester became a centre for immigration campaigning over the years. The class and intellectual base of Manchester may be one of the reasons why their focus was largely on campaigning against the immigration laws rather than on issues of community self-defence. 
Although more women were involved in Manchester, the treatment of women in both the Bradford and Manchester AYMs was commented on by one of the women members in Manchester, Kuldeep, in quite favourable terms. She came from Southall to Manchester as a student and she compares the three organisations:

'what I like about Manchester was it was quite formal, and I think this is something, that discipline ... I think Bradford AYM was an inspiration in the way they were structured and they were quite formal about things in a way I think Southall wouldn't have been, because Southall had a degree of familiarity and a bit of a macho culture. And I liked the formality of Bradford and Manchester; their structures, committees, Chairs, you know, appointments, all that kind of stuff... it was not just about people's egos and about people who were popular being appointed to positions and it was more democratic and fair, and encouraged women to get involved as well as stand for positions... People were much more committed to the cause and it was less about egos. ${ }^{\prime} 44$

Kuldeep's comments make it important to look at the similarities as well as the differences of the various youth movements and perhaps the recognition by some members in Bradford of the political maturity of some of the AYM (Manchester) members, could imply that the methods and involvement of women in Manchester impacted on Bradford. It was in fact after the AYM (Manchester) was established that more women were involved in Bradford.

It is clear that the two organisations influenced each other in their work. The AYM (Bradford) had in fact supported the development of the AYM (Manchester) sending speakers to initial meetings to talk about the need for an AYM and to support the development of a youth movement in Manchester. The AYMs in Manchester and Bradford worked closely with each other for about 2-3 years from 1979-1982 and members of both Asian youth movements believed in the need for a national movement. Although this was never actually established, the fact that they chose to call themselves the AYM (Bradford) and the AYM (Manchester) rather than the Manchester AYM or the Bradford AYM was because they wanted to establish names that would suggest that they were branches of the same organisation. If we look at the aims and objectives of the AYM (Manchester) and the AYM (Bradford) they are almost identical. The AYM (Manchester) in fact appears to have copied the aims and objectives from Bradford's magazine Kala Tara when they established and published their own magazine, Liberation a year later. The close ties were partly created because two of the student members in the AYM (Manchester) were from Bradford and had been involved in the AYM (Bradford) before coming to Manchester. One of their elder brothers remained involved in the AYM (Bradford) so familial and friendship connections obviously created a strong bond. The two organisations supported each other's activities and also worked together in organising one key campaign - the Anwar Ditta Defence Campaign. ${ }^{45}$ Both AYMs in Manchester and Bradford were instrumental in enabling Anwar to successfully win the right to bring her young children to England in 1981, even when all legal processes of appeal were lost.

The close interrelationship should not however cloud a fundamental difference between the two organisations, which I think impacted on the legacy of influence in the towns in which they operated. Bradford, as a larger AYM with a range of younger members who had few family commitments, had members travel to various parts of the country, supporting activity in London, Sheffield, Southall, Leicester, Birmingham. As organisers from a left tradition, they realised the importance of building networks and their youthful energy enabled them to do this, while at the same time having a very strong local community base. Manchester did share some of these links but the more limited size of their organisation and the members' commitments in terms of jobs and families did not enable them to move for weeks or months to help organisers in other areas. Manchester, however, like all AYMs did support sister organisations in campaigns against police victimisation, deportation and in international solidarity campaigns including the anti-apartheid struggle, the Irish republican struggle and the Palestinian struggle. They attended meetings, demos and pickets. Bradford's strong base within a working class community also made them much more able and interested in supporting workers and trade union struggles. Manchester did not organise trade union activity, although they 
supported such activity, since as students and community workers, they were much less involved with workers' struggles on a day to day level.

Bradford generally was more prolific in terms of its organisational activity. Its size and its rootedness within Bradford as well as the young men's ability and energy to travel and make links meant that they were involved with dozens of anti-deportation campaigns, anti-fascist actions, campaigns against police violence, international issues such as Palestine, Ireland and the revolution in Iran. But they never forgot the importance of local community activity, and, for example, were instrumental in the success of the Drummond School Parents Action Committee which eventually led to the sacking of the racist Headmaster Ray Honeyford.

There is one final comparison that should be highlighted between Manchester and Bradford which enables us to think about the organisations and their impact, and that is the memory of them in the two cities. In Manchester itself there is very little community memory of the AYM and its activities, partly because the movement was smaller, but also because as a city with aspiring individuals and as an organisation partly made up of students, the majority of the key AYM members do not live in Manchester anymore. Many have moved to London. In Bradford there are many individuals who are still active in the city, in different - often more official capacities - as youth workers, education officers and one as an MP, but they are still there, as are others that worked on the fringes of the organisation. The AYM (Bradford) also continued as an organisation until 1989, although by this stage it had been absorbed into council structures and operated as a youth Centre. The AYM (Manchester) started later and had dissipated long before the AYM (Bradford) collapsed. The town of Bradford too and the local paper, The Telegraph and Argus retain the memory of the AYM and recalled them when the riots took place in 2001. As Anwar mentioned when talking about the 2001 riots:

'the newspaper after the troubles, The Telegraph and Argus said 'we wish the Asian Youth Movement was round again, at least with the Asian Youth Movement we could speak. ${ }^{146}$

Although the organisation in Bradford split into the AYM (Bradford) and the United Black Youth League (UBYL) in early 1981,47 their prolific activity and also their uncompromising belief in their right to defend themselves also explains why the Bradford 12 case took place in Bradford as opposed to a city like Manchester and why it won such widespread support. As one of the defence solicitor's from the trial, Ruth Bundy commented, 'it was the sons of the community that were on trial'. . $^{8}$ The Bradford 12 were charged with conspiracy to cause explosives and endanger lives after petrol bombs that had not been used were found in undergrowth after July 11th when it had been rumoured that fascists were coming to Bradford. The defence case rested on the right of the community to self-defence. The response to the campaign and their need for support which was given nationally was in many ways driven by their phenomenal ability in the previous years to make links, support other groups and individuals across the country in almost every town that had begun to organise. There were also other reasons which had national resonance such as the disturbances in towns and cities across the country in 1981 which meant that anti-racists nationally were looking to support a campaign against police victimisation and repression. It is undoubtedly the case however, that the AYM and UBYL, through local community organisation created a national campaign and legal history of the right of a community to self-defence.

It is clear from exploring the experiences of two Asian Youth Movements, that thinking about local experiences enables us to understand how and why community organisations develop in particular ways and with particular strengths. AYM (Bradford)'s integration with the local community enabled it to be large and influential. The experience of white left organisations by central members of the AYM enabled them to develop structures that would formalise the movement quite quickly. Physical landmarks such as the Central Library and the Fourth Idea Bookshop also enabled the youth. The movement was also made of very young school aged males and this characterised the way they worked 
including the activities which led to the Bradford 12 trial. Manchester with its older, middle class and intellectual base was calmer and formal in its structures. They were able to see the importance of involving women within the organisation, but were also hampered in their activities by the lack of an effective community base in any particular area. The nature of the cities themselves and the histories of migrations within them also impacted on the nature of the organisations that developed.

1. Renton, David. When we Touched the Sky: The Anti-Nazi League 1977-1981. Cheltenham: New Clarion Press, 2006; Shukra, Kalbir. The Changing Pattern of Black Politics in Britain, London: Pluto Press, 1998; Ramamurthy, Anandi. The Politics of Britain's Asian Youth Movements. Race \& Class,48(2), 2006, p.386o; Cohen, P. and Bains, H. Multi-Racist Britain. London: Macmillan, 1988; Hann, D. and Tilzey, S. No Retreat. Preston: Milo Books, 2003; Sivanandan, A. Communities of Resistance. London: Verso, 1990.

2. Sivanandan, A From Resistance to Rebellion: Asian and Afro-Caribbean Struggles in Britain. London: Institute of Race Relations, 1986, p40-41.

3. Sivanandan, see also Fryer, Peter. Staying Power. London: Pluto, 1987. Ramdin, Ron. The Making of the Black Working Class in Britain. Aldershot: Wildwood House, 1987.

4. Rex and Tomlinson. Colonial Immigrants in a British City: A Class Analysis, London: Routledge, 1979 .

5. Moye, J. Todd. Let the People Decide: Black Freedom and White Resistance Movements in Sunflower County, Mississippi 1945-1980. North Carolina: University of North Carolina Press, 2004.

6. Campaign Against Racism and Fascism. Southall: The Birth of a Black Community. CARF/Southall Rights, 1981;

7. Campaign Against Racism and Fascism. Newham: The Forging of a Black Community CARF/ NMP, 1991. See Sivanandan (ref.2).

8. Shukra (ref.1, p.45).

9. Castells, Manuel. The City and the Grassroots: A Cross-cultural Theory of Urban Social Movements. Berkeley: University of California Press,1983, p.11.

10. Alleyne, Brian. Radicals Against Race: Black Activism and Cultural Politics. Oxford: Berg, 2002.

11. Cohen, Abner. Urban Ethnicity. London: Routledge, 1974/2004.

12. Interview with Anwar Qadir, member of AYM (Bradford), 2007.

13. Interview with Noorzaman Rashid, member of AYM (Bradford), 2007.

14. Dahya, B. (1974). The nature of Pakistani Ethnicity in Industrial Cities in Britain. In: Cohen (ref. 11. p.83).

15. Interview with Anwar Qadir (ref. 12).

16. Dahya (ref. 14, p.90).

17. Interview with Noorzaman Rashid (ref.13).

18. Interview with Jani Rashid, member of AYM (Bradford), 2007.

19. See Hayes, Mark and Aylward, Paul. Anti-Fascist Action Radical Resistance or Rent-a-Mob? Soundings, 14(Spring), 2000. Renton (ref. 1); Hann, D and Tilzey, S (ref. 1).

20. Interview with Jani Rashid (ref. 18).

21. Interview with Tariq Mehmood, (member of AYM (Bradford) and later United Black Youth League), (2007).

22. Defend Manningham. Race Today. May, 1976.

23. Campaign against Racism and Racism (1981), (ref. 6).

24. Interview with Balraj Purewal, Member of Southall Youth Movement.

25. De Witt, John. Indian Workers' Associations in Britain. London: Oxford University Press, 1969, pp.1589.

26. Interview with Dave Stark, (member of Bradford Trades Council during the 1970 and 1980 and active anti-fascist campaigner), 2007.

27. 'Jagtor Singh Sahota, Sectretary of the IWA, Interviewed by Yogesh Patel' in Kala Tara, magazine of the Asian Youth Movement (Bradford), 1979.

28. Mehmood, Tariq. Hand on the Sun. Harmondsworth: Penguin, 1983, p.88.

29. The third member whom I interviewed, is now an MP and therefore relates the stories of his past in ways that do not contradict the image he wishes to present in the Labour Party.

30. Interview with Tariq Mehmood, (ref. 21).

31. Interview with Jani Rashid, (ref. 18).

32. Interview with Tariq Mehmood, (ref.21).

33. Bradford Libraries, Archives and Information Service. African-Caribbean and Asian. [Online].(retrieved 
January 17, 2011). (Url http://www.bradlibs.com/localstudies/vtc/destinationbradford/people/asian_ africancaribbean.htm)

34. For a discussion of the macho, physical and work related characteristics of northern masculinities see for example Winlow, Simon . Badfellas: Crime, Tradition and New Masculinities. Oxford: Berg, 2001, pp.25-58.

35. Russell, Dave Looking North : Northern England and the National Imagination. Manchester: Manchester University Press, 2004; Kirk, N. Northern Identities : Historical Interpretations of The North' and Northernness'. Aldershot, Ashgate, 2000.

36. Interview with Gurnam Singh, member of Asian Youth Movement (Bradford), 2007.

37. Interview with Tariq Mehmood (ref. 21).

38. Kalra, V. Writing British Asian Manchester. From Diasporas to Multi-Locality: Writing British Asian Cities, Leeds: Leeds University, 2009.

39. Taylor, I. Evans, K. \& Fraser, P. A Tale ofTwo Cities London: Routledge, 1996. p. 204-5.

40. Werbner, P. Migration Processes. Oxford: Berg, 1990.

41. Kalra, V. From Textile Mills to Taxi Ranks: Experiences of Migration, Labour and Social Change Aldershot:Ashgate, 2000.

42. Interview with Nilofer Shaikh, member of AYM, (Manchester), 2007.

43. Interview with Mohsin Zulfiqa, member of AYM, (Manchester), 2007.

44. Kuldeep Mann, member of Asian Youth Movement, (Manchester).

45. Anwar Ditta was a woman in Rochdale who fought to be reunited with her children who she had left in Pakistan while she re-established her home in Britain. She was born in Birmingham and had been sent by her father to Pakistan as a young girl.

46. Anwar Qadir, (ref. 12).

47. This split did not reflect a turn to black separatist politics as Farzana Shain suggests but was in fact over the issue of applying for state funding. See Shain, Farzana. Uneasy Alliances: British Muslims and Socialists since the 1950s. Journal of Communist and Transition Politics 25(1), 2009, pp.95-109.

48. Ruth Bundy, interview, 2007. 


\title{
Comment
}

\author{
And \\ Opinion
}




\title{
Comment and Opinion
}

\section{Blacks and the 2010 Midterms: A Preliminary Analysis}

\author{
David A. Bositis \\ Senior Political Analyst \\ The Joint Center for Political and Economic Activities
}

What follows is a brief review of some of the available evidence on what transpired on November 2, 2010, when the Democrats lost their majority in the US House of Representatives and at least 19 state legislative chambers, maintained control in the US Senate, and lost several important gubernatorial elections. The black vote was critical to the outcome of some closely contested elections, but not enough in many more. In particular, this review will focus on the behavior and significance of AfricanAmerican voters in the 2010 midterm elections; and the changing numbers and profile of black candidates for both federal and statewide office, as well as their performance at the polls.

\section{Black Voter Turnout in the 2010 Midterms: National}

National turnout in the 2010 midterms is up slightly from 2006. The Committee for the Study of the American Electorate estimates that 90 million total voters turned out on November 2, and overall turnout increased slightly from 40.8 percent in 2006 to 42.0 percent in 2010. Black voters turned out at slightly higher rates than in 2006 , reflecting the overall small secular increase. According to exit polls, the black share of the 2010 vote was 10 percent [Table 1]; the black share was also 10 percent in the 2006 midterms. This is a smaller percentage than in the 2008 presidential election when it was 13 percent, but presidential and midterm elections are not comparable, and further, 2008 was the first time an African American was a major party nominee for president. Thus, on balance, there is no evidence of a decline in the black vote nationally, but rather, black turnout appears to have increased slightly from the previous midterms.

\begin{tabular}{|c|c|c|c|c|c|c|c|c|c|}
\hline \multicolumn{3}{|c|}{$\begin{array}{c}\text { Black Share of the Total } \\
\text { Electorate }\end{array}$} & \multirow[b]{2}{*}{ GROUP } & \multicolumn{2}{|c|}{$\begin{array}{c}\text { Congressional Vote } \\
2006\end{array}$} & \multicolumn{2}{|c|}{$\begin{array}{l}\text { Presidential Vote } \\
2004\end{array}$} & \multicolumn{2}{|c|}{$\begin{array}{c}\text { Congressional Vote } \\
2010\end{array}$} \\
\hline $\begin{array}{c}2006 \\
\%\end{array}$ & $\begin{array}{c}2008 \\
\%\end{array}$ & $\begin{array}{c}2010 \\
\%\end{array}$ & & $\begin{array}{c}\text { Dem } \\
\%\end{array}$ & $\begin{array}{l}\text { Rep } \\
\%\end{array}$ & $\begin{array}{l}\text { Obama } \\
\%\end{array}$ & $\begin{array}{l}\text { McCain } \\
\%\end{array}$ & $\begin{array}{c}\text { Dem } \\
\%\end{array}$ & $\begin{array}{l}\text { Rep } \\
\%\end{array}$ \\
\hline 10 & 13 & 10 & Total Black Population & 89 & 11 & 95 & 4 & 90 & 9 \\
\hline 5 & 5 & 4 & Black Men & 87 & 13 & 95 & 5 & 84 & 14 \\
\hline 6 & 7 & 6 & Black Women & 91 & 9 & 96 & 3 & 93 & 6 \\
\hline
\end{tabular}

The Committee for the Study of the American Electorate also reports that the Republican vote in 2010 increased 2.1 percentage points from 2006, and the Democratic vote declined 4.7 percentage points.

\section{Black Voter Turnout in the 2010 Midterms: the States}

While black turnout nationally increased slightly between 2006 and 2010, the magnitude of black turnout across the country varied significantly from state to state [Table 2]. Our understanding of the total picture on black turnout - at least at this time - is made more difficult because there were several states with large black populations where state-specific exit polls were not conducted, including Alabama, Georgia, and Maryland. Black turnout information for these states will not be available until 


\begin{tabular}{|c|c|c|c|c|c|c|c|c|c|c|c|}
\hline \multirow{3}{*}{ State } & \multirow{3}{*}{$\begin{array}{l}\text { BVAP } \\
(\%)\end{array}$} & \multicolumn{3}{|c|}{$\begin{array}{c}\text { Black Share of the Total } \\
\text { Vote: Exit Polls }\end{array}$} & \multicolumn{3}{|c|}{ Total Vote Turnout } & \multicolumn{4}{|c|}{ Black Partisan Vote } \\
\hline & & \multirow{2}{*}{$\begin{array}{c}2006 \\
(\%)\end{array}$} & \multirow{2}{*}{$\begin{array}{c}2008 \\
(\%)\end{array}$} & \multirow{2}{*}{$\begin{array}{c}2010 \\
(\%)\end{array}$} & \multirow{2}{*}{$\begin{array}{c}2006 \\
(\%)\end{array}$} & \multirow{2}{*}{$\begin{array}{c}2008 \\
(\%)\end{array}$} & \multirow{2}{*}{$\begin{array}{c}2010 \\
(\%)\end{array}$} & \multicolumn{2}{|c|}{ Democrat } & \multicolumn{2}{|c|}{ Republican } \\
\hline & & & & & & & & Gov & Sen & Gov & Sem \\
\hline California & 6.4 & 5 & 10 & 9 & 38.4 & 51.2 & $\mathrm{n} / \mathrm{a}$ & 77 & 80 & 21 & 17 \\
\hline Delaware & 19.6 & $\mathrm{n} / \mathrm{a}$ & 17 & 22 & $45 \cdot 5$ & 63.0 & $47 \cdot 3$ & - & 93 & - & 6 \\
\hline Florida & 14.7 & 14 & 13 & 11 & 38.4 & 56.5 & 39.5 & 92 & 76 & 6 & 4 \\
\hline Illinois & 13.8 & 10 & 17 & $19 / 20^{1}$ & 41.0 & 57.1 & 42.9 & 90 & 94 & 10 & 6 \\
\hline Indiana & 8.1 & $\mathrm{n} / \mathrm{a}$ & 7 & 12 & 36.6 & 58.8 & 37.5 & - & 82 & - & 14 \\
\hline Kentucky & 7.1 & $\mathrm{n} / \mathrm{a}$ & 11 & 6 & 40.2 & $61 . .4$ & 42.4 & - & 86 & - & 13 \\
\hline Louisiana & 30.6 & $\mathrm{n} / \mathrm{a}$ & 29 & 24 & 27.7 & 68.0 & 37.4 & - & 86 & - & 11 \\
\hline Missouri & 10.4 & 13 & 13 & 13 & 49.7 & 64.2 & 44.0 & - & 92 & - & 5 \\
\hline Nevada & 8.3 & 6 & 10 & 6 & 36.8 & 52.8 & 41.3 & 86 & 78 & 10 & 11 \\
\hline New York & 14.8 & 10 & 17 & 18 & 35.2 & 51.5 & 32.5 & 93 & $\begin{array}{c}94 \\
(\mathrm{~s}: 90) \\
\end{array}$ & 6 & $\begin{array}{c}6 \\
(s: 7) \\
\end{array}$ \\
\hline Ohio & 10.6 & 12 & 11 & 15 & 47.2 & 68.7 & 43.4 & 90 & 85 & 8 & 9 \\
\hline Pennsylvania & 9.6 & 8 & 13 & 9 & 43.6 & 60.8 & 41.1 & 91 & 92 & 8 & 7 \\
\hline Texas & 11.6 & 8 & 13 & 13 & 32.3 & 48.8 & 32.3 & 88 & - & 11 & - \\
\hline \multicolumn{12}{|c|}{$\begin{array}{l}\text { Information on the black voting-age population and } 2009 \text { total turnout is from the U.S. Census, Current Population } \\
\text { Surveys, } 2008 \text {. The black share of the total vote for } 2006 \text { and } 2008 \text { are from the Edison-Mitofsky consortium exit } \\
\text { polls. Total turnout figures for } 2006 \text { and estimated turnout figures for } 2010 \text { are from the Committee for the Study of } \\
\text { the American Electorate. } 1 \text {. According to the exit polls, black voters represented } 19 \text { percent of the total votes cast for } \\
\text { governor and } 20 \text { percent of the total for U.S. Senator. }\end{array}$} \\
\hline
\end{tabular}

the US Census Bureau releases its report on Registration and Voting from the November 2010 CPS, which is likely to be at least a year hence.

There were several states where the exit polls indicate that black turnout increased substantially. However, in some of these states, nonhispanic white support went so strongly for the opposing side, that the black vote was not determinative. Given the small increase in the black vote nationally, but large increases in the black vote in some of the largest states, black turnout was certainly flat or declined significantly in some states.

While black turnout nationally increased only modestly, black turnout in 2010 was strategically effective in a few places, although not enough in others. There were large and impressive increases in black turnout in California, Delaware, Illinois, NewYork, Ohio, Texas, and perhaps Indiana; there were small increases in Pennsylvania and Nevada. Turnout was flat but strong in Missouri. For Indiana, there is no 2006 data to use as a comparison, but the black share of the state vote was higher in 2010 than it was in 2008, a banner year for black turnout. Finally, there was a significant decline (about 21 percent) in the black share of the state vote in Florida-from 14 percent in 2006 to 11 percent in 2010.

It is important for the narrative of the 2010 midterm elections to examines where black voters were a critical factor in the outcome of the elections. Strong black turnout in New York, California, and Delaware certainly contributed to a strong Democratic showing in those states. In New York, black voters increased from 10 percent of all voters in 2006 to 18 percent in 2010, and in California (where the Democrats won all of the top offices) the black share of the vote nearly doubled from 2006 with the black share increasing from five to nine percent; in Delaware, where the black share of the vote was at an all time high at 22 percent, the Democrats held the US Senate seat of Vice-President Biden and picked up a seat in the US House. The increase in black turnout in Nevada also contributed to 
Senate majority leader's Harry Reid's re-election, and while there were no exit polls in Connecticut, the Democrats held retiring Senator Chris Dodd's seat, and took over the Governor's office; the GOP candidate for governor was leading until the results from Bridgeport, which has a large black population, were counted.

Probably the two states most emblematic of 2010 for black voters were Illinois and Ohio. Black turnout in Illinois was spectacular for a midterm election. The black share of the total vote in Illinois increased from 10 percent in 2006 to 19 percent in 2010 (20 percent in the US Senate contest). At the top of the ticket in Illinois were competitive US Senate (President Obama's seat) and Governor races. According to the exit polls, in the US Senate race, the Democratic Alexi Giannoulias received 31 percent of the white vote and lost a very close race to Republican Mark Kirk. In the Governor's race, Democrat Pat Quinn received 33 percent of the white vote and won a close race. Thus, due to a strong black turnout, a Democrat is elected governor with only one-third of the white vote, and a Democrat loses a close race for the US Senate despite a strong black vote because he could not manage to win the votes of even one-third of whites.

Ohio was another state where the black vote increased significantly, increasing from 12 percent of all voters in 2006 to 15 percent of all voters in 2010 . However, the statewide Democratic candidates did not receive the support of enough white voters to win. Ted Strickland, the Democrat's candidate for governor, received only 38 percent of the white vote, and thus, despite a strong black vote, he lost a close election.

There were other states where a solid black turnout was insufficient to change the outcome because the Democratic candidate failed to get enough white support to emerge victorious. Pennsylvania Democratic US Senate candidate received solid black support but his 43 percent white support was insufficient to win in a very close election. Democrat Robin Carnahan had even stronger black support in her US Senate run in Missouri, but she failed to get even one-third of the white vote.

The narrative of US House races was very similar. The Democrats lost over 60 seats in 2010, including more than a dozen in districts with a significant black vote. In districts with at least 10 percent black voting-age population, the Democrats lost seats in Alabama (1), Arkansas (2), Florida (2), Louisiana (1), Maryland (1), Mississippi (2), Ohio (2), South Carolina (1), Tennessee (1), Texas (1), and Virginia (2). However, Democrats held on to House seats in such districts in North Carolina, Ohio, and Virginia, and picked up seats in Delaware and Louisiana (New Orleans).

\section{A Perspective on 2010 and 2012}

The results of 2010 Midterms--held during a period of severe economic downturn--were a repudiation of the party in power, the Democrats, as is always the case during periods of economic distress. Turnout was about 42 percent versus about 60 percent in 2008 . There were 29 million people who voted for President Obama in 2008 who did not turn out in 2010. The exit polls suggest that the people who voted in 2010 - much older and whiter than the electorate in 2008- liked the Republican party no more than the Democratic party. The Republicans gained control of one branch of the federal legislature in Washington; they do not control the federal government. There is another important datum from the 2010 elections that has been little noted: many of the gains that the Republicans made were by the slimmest of margins in US Senate races, Governor's races, and US House races. Every year that passes, the US population becomes less white, with the white working class especially in decline. The winning Republican US Senate and Governor candidates will not be on the ballot in 2012, when the composition of the electorate will be quite different than it was in 2010, but all of the newly elected Republican US House members will be on the ballot--and an improved economy and a different electorate could easily change the new status quo. 


\section{African-American Voters: Partisan Direction in the 2010 Midterms}

Across the country, the black vote in US House elections was 90 percent Democratic and nine percent Republican [Table 1]. There again was a gender gap among African-Americans in 2010 with black women (93 percent Democratic vs. six percent Republican) voting more Democratic than black men ( 84 vs. 14 percent). The black vote in 2010 was three-to-two female to male as has been the case in many recent elections.

As expected, there was no partisan shift toward the Republican party given their attacks on President Obama, who remains exceptionally popular with African-Americans. There were very few individual Republican candidates who fared better with black voters than the black population's partisanship would anticipate [Table 2]; the GOP's two losing candidates at the top of the ticket in California, Meg Whitman (21 percent) and Carly Fiorina (17 percent) were the only Republicans who garnered above average support from African-Americans.

\section{Black Candidates for Statewide Constitutional Office in 2010}

There were 16 black candidates who sought statewide constitutional office in 2010 [Table 3a], six women and ten men. The 16 candidates included 15 Democrats, and one Republican. Of the 16 black

\begin{tabular}{|c|c|c|c|c|}
\hline State & $\begin{array}{l}\text { BVAP } \\
(\%)\end{array}$ & Office & Black Nominee(s) & Vote \\
\hline$A L$ & & State Auditor & Miranda Joseph (D)? & 38 \\
\hline CA & & Attorney General & Kamala Harris (D)> & $\mathrm{n} / \mathrm{a}$ \\
\hline $\mathrm{CT}$ & & Treasurer & (x) Denise Nappier (D)> & 54 \\
\hline DE & & Treasurer & Chip Flowers (D)> & 51 \\
\hline $\mathrm{FL}$ & & $\begin{array}{c}\text { US Senator } \\
\text { Lieutenant Governor }^{1}\end{array}$ & $\begin{array}{l}\text { Kendrick Meek (D)? } \\
\text { Jennifer Carroll }(R)>\end{array}$ & $\begin{array}{l}20 \\
49\end{array}$ \\
\hline GA & & $\begin{array}{l}\text { US Senator } \\
\text { Secretary of State }\end{array}$ & $\begin{array}{l}\text { Michael Thurmond (D)? } \\
\text { Georganna Sinkfield (D)? }\end{array}$ & $\begin{array}{l}39 \\
39 \\
\end{array}$ \\
\hline IL & & Secretary of State & (x) Jesse White (D)> & 70 \\
\hline IN & & Secretary of State & Vop Osili (D)? & 37 \\
\hline MD & & Lieutenant Governor $^{1}$ & (x) Anthony Brown (D)> & 56 \\
\hline MA & & Governor & (x) Deval Patrick (D)> & 48 \\
\hline NM & & Treasurer & (x) James Lewis $(\mathrm{D})>$ & 54 \\
\hline $\mathrm{OH}$ & & $\begin{array}{l}\text { Lieutenant Governor }^{1} \\
\text { Treasurer }\end{array}$ & $\begin{array}{l}\text { Yvette McGee Brown (D)? } \\
\text { Kevin Boyce (D)? }\end{array}$ & $\begin{array}{l}47 \\
40\end{array}$ \\
\hline SC & & US Senator & Alvin Greene (D)? & 28 \\
\hline \multicolumn{5}{|c|}{$\begin{array}{l}\text { (x) Incumbent } 1 . \text { Governor and Lieutenant Governor run together on the same ticket. } \\
>\text { Won ? Lost }\end{array}$} \\
\hline
\end{tabular}

candidates for statewide office, eight were winners--seven Democrats and the lone Republican.

Among the Democratic statewide nominees, the most prominent victors were Massachusetts Governor Deval Patrick, re-elected to a second term; this is the first time a black governor has been re-elected. Also re-elected was Maryland Lieutenant Governor Anthony Brown, and in a first, 


\begin{tabular}{|c|c|c|c|}
\hline \multicolumn{2}{|c|}{ Table 3b. Statistical Profile, Black Major Party Nominees for Statewide Office, 2010} \\
\hline \multicolumn{2}{|c|}{ Democrats } & \multicolumn{2}{c|}{ Republicans } \\
\hline Won & Lost & Won & $(\mathrm{N})$ \\
$(\mathrm{N})$ & $(\mathrm{N})$ & $(\%)$ & $(\%)$ \\
\hline$(\%)$ & $(\%)$ & 1 & 0 \\
\hline 7 & 8 & 100.0 & 0.0 \\
\hline 46.7 & 53.3 & & 0 \\
\hline
\end{tabular}

Republican Jennifer Carroll was elected the Lieutenant Governor of Florida. Other noteworthy firsts were the election of Kamala Harris to be California Attorney General, and Chip Flowers was elected Delaware's Treasurer, the first time a black candidate won statewide office in Delaware. Finally, longtime officeholders Illinois Secretary of State Jesse White, Connecticut Treasurer Denise Nappier, and New Mexico Treasurer James Lewis were returned to office.

\section{Black Candidates for Federal Office in the 2010 Midterms}

In 2010, there were 63 black candidates for federal office, 60 for US House seats and three for US Senate seats [Tables 4, 5, and 6]. This was an increase from 56 in 2008 and 57 in 2006. The 2008-2010 increase included six more Republicans and one additional Democrat; the 48 Democratic candidates equals the all-time high.

Of the 48 black Democratic nominees in 2010, 37 were black incumbents and 11 were challengers or running for open seats. For the first time since 1994, two Republicans were elected to the US House; Tim Scott was unopposed in SC-1 and Alan West defeated incumbent Ron Klein in FL-22. The remaining 13 Republican candidates all were defeated. The number of black women among the Democratic nominees equalled the previous record (17) and more were victorious than ever before (15). No incumbent CBC member ran unopposed in 2010, a first since the Joint Center began tracking black candidates in 1990. There were also a record number of black-white contests in the 2010 midterms (44).

The outcomes of the 2010 midterms for black federal candidates were generally favorable [Table 6], with all black incumbents re-elected, and several new black members elected to the US House. Black membership in the US House will be at an all-time high in the new congress with 44 black members, 42 U.S. Representatives and two Delegates. As noted above, there will be two new black Republicans in the US House. Representative-elect Cedrick Richmond (D-LA-2) represents an additional black Democrat in the US House, and four black freshman Democrats are replacing CBC members who retired, lost in the primaries, or ran for other office: Terri Sewell (AL-7), Karen Bass (CA-35), Frederica Wilson (FL-17), and Hansen Clarke (Ml-13).

Winning black Democrats who faced opposition averaged 72.6 percent of the vote, while the one winning Republican with opposition received 54.0 percent. The six losing black Democratic candidates averaged 33.7 percent of the vote, while the 13 losing black Republican candidates averaged 27.8 percent.

\section{The State Legislatures' Post 2010}

The Democrats took a very severe beating at the state legislative level, losing at least 675 seats and legislative control in at least 19 chambers nationwide. In several states with significant black populations, the Republicans control both chambers of the state legislature as well as the governor's office. These states include Alabama, Georgia, Florida, Michigan, Ohio, Pennsylvania, South Carolina and Texas. This of course will be very painful during the upcoming redistricting process. About the only favorable circumstances for the post-2010 redistricting are in California and Connecticut, where the Democrats control the entire process, and Virginia, where the Democrats control the state senate; in 


\begin{tabular}{|c|c|c|c|c|c|c|c|c|c|c|c|c|c|c|c|c|c|c|}
\hline & \multicolumn{6}{|c|}{ Democrats } & \multicolumn{6}{|c|}{ Republicans } & \multicolumn{6}{|c|}{ Total } \\
\hline & $\begin{array}{c}2000 \\
N \\
\%\end{array}$ & $\begin{array}{c}2002 \\
N \\
\%\end{array}$ & $\begin{array}{c}2004 \\
N \\
\%\end{array}$ & $\begin{array}{c}2006 \\
N \\
\%\end{array}$ & $\begin{array}{c}2008 \\
N \\
\%\end{array}$ & $\begin{array}{c}2010 \\
N \\
\%\end{array}$ & $\begin{array}{c}2000 \\
N \\
\%\end{array}$ & $\begin{array}{c}2002 \\
N \\
\%\end{array}$ & $\begin{array}{c}2004 \\
\mathrm{~N} \\
\%\end{array}$ & $\begin{array}{c}2006 \\
N \\
\%\end{array}$ & $\begin{array}{c}2008 \\
N \\
\%\end{array}$ & $\begin{array}{c}2010 \\
\mathrm{~N} \\
\%\end{array}$ & $\begin{array}{c}2000 \\
N \\
\%\end{array}$ & $\begin{array}{c}2002 \\
N \\
\%\end{array}$ & $\begin{array}{c}2004 \\
N \\
\%\end{array}$ & $\begin{array}{c}2006 \\
N \\
\%\end{array}$ & $\begin{array}{c}2008 \\
N \\
\%\end{array}$ & $\begin{array}{c}2010 \\
\mathrm{~N} \\
\%\end{array}$ \\
\hline Total & $\begin{array}{r}46 \\
100 \\
\end{array}$ & $\begin{array}{c}45 \\
100 \\
\end{array}$ & $\begin{array}{c}47 \\
100 \\
\end{array}$ & $\begin{array}{c}48 \\
100\end{array}$ & $\begin{array}{c}47 \\
100 \\
\end{array}$ & $\begin{array}{c}48 \\
100 \\
\end{array}$ & $\begin{array}{c}24 \\
100 \\
\end{array}$ & $\begin{array}{c}10 \\
100\end{array}$ & $\begin{array}{c}15 \\
100\end{array}$ & $\begin{array}{c}9 \\
100\end{array}$ & $\begin{array}{c}9 \\
100\end{array}$ & $\begin{array}{c}15 \\
100\end{array}$ & $\begin{array}{c}70 \\
100\end{array}$ & $\begin{array}{c}55 \\
100 \\
\end{array}$ & $\begin{array}{c}62 \\
100 \\
\end{array}$ & $\begin{array}{c}57 \\
100\end{array}$ & $\begin{array}{c}56 \\
100\end{array}$ & $\begin{array}{c}93 \\
100 \\
\end{array}$ \\
\hline Incumbents & $\begin{array}{l}37 \\
80 \\
\end{array}$ & $\begin{array}{l}34 \\
76 \\
\end{array}$ & $\begin{array}{l}38 \\
81 \\
\end{array}$ & $\begin{array}{l}39 \\
81 \\
\end{array}$ & $\begin{array}{l}41 \\
87 \\
\end{array}$ & $\begin{array}{l}37 \\
77\end{array}$ & $\begin{array}{l}1 \\
4 \\
\end{array}$ & $\begin{array}{l}0 \\
0\end{array}$ & $\begin{array}{l}0 \\
0\end{array}$ & $\begin{array}{l}0 \\
0\end{array}$ & $\begin{array}{l}0 \\
0\end{array}$ & $\begin{array}{l}0 \\
0\end{array}$ & $\begin{array}{l}38 \\
54\end{array}$ & $\begin{array}{l}34 \\
62 \\
\end{array}$ & $\begin{array}{l}38 \\
61\end{array}$ & $\begin{array}{l}39 \\
68 \\
\end{array}$ & $\begin{array}{l}41 \\
73 \\
\end{array}$ & $\begin{array}{l}37 \\
59 \\
\end{array}$ \\
\hline $\begin{array}{l}\text { Challenger } \\
\text { Open Seat }\end{array}$ & $\begin{array}{c}9 \\
20\end{array}$ & $\begin{array}{l}11 \\
24 \\
\end{array}$ & $\begin{array}{c}9 \\
19 \\
\end{array}$ & $\begin{array}{c}9 \\
19 \\
\end{array}$ & $\begin{array}{c}6 \\
13 \\
\end{array}$ & $\begin{array}{l}11 \\
23 \\
\end{array}$ & $\begin{array}{l}23 \\
96 \\
\end{array}$ & $\begin{array}{c}10 \\
100 \\
\end{array}$ & $\begin{array}{c}15 \\
100 \\
\end{array}$ & $\begin{array}{c}9 \\
100 \\
\end{array}$ & $\begin{array}{c}9 \\
100 \\
\end{array}$ & $\begin{array}{c}15 \\
100 \\
\end{array}$ & $\begin{array}{l}32 \\
46 \\
\end{array}$ & $\begin{array}{l}21 \\
38 \\
\end{array}$ & $\begin{array}{l}24 \\
39 \\
\end{array}$ & $\begin{array}{l}18 \\
32 \\
\end{array}$ & $\begin{array}{l}15 \\
27 \\
\end{array}$ & $\begin{array}{l}26 \\
41 \\
\end{array}$ \\
\hline Women & $\begin{array}{l}15 \\
33\end{array}$ & $\begin{array}{l}13 \\
29\end{array}$ & $\begin{array}{l}16 \\
34\end{array}$ & $\begin{array}{l}17 \\
35\end{array}$ & $\begin{array}{l}16 \\
34\end{array}$ & $\begin{array}{l}17 \\
35\end{array}$ & $\begin{array}{c}8 \\
33\end{array}$ & $\begin{array}{c}3 \\
30\end{array}$ & $\begin{array}{c}5 \\
33\end{array}$ & $\begin{array}{c}4 \\
44\end{array}$ & $\begin{array}{c}2 \\
22\end{array}$ & $\begin{array}{c}2 \\
13\end{array}$ & $\begin{array}{l}23 \\
33\end{array}$ & $\begin{array}{l}16 \\
29\end{array}$ & $\begin{array}{l}21 \\
34\end{array}$ & $\begin{array}{l}21 \\
37\end{array}$ & $\begin{array}{l}18 \\
32\end{array}$ & $\begin{array}{l}19 \\
30\end{array}$ \\
\hline Men & $\begin{array}{l}31 \\
67\end{array}$ & $\begin{array}{l}32 \\
71\end{array}$ & $\begin{array}{l}31 \\
66 \\
\end{array}$ & $\begin{array}{l}31 \\
65 \\
\end{array}$ & $\begin{array}{l}31 \\
66 \\
\end{array}$ & $\begin{array}{l}31 \\
65\end{array}$ & $\begin{array}{l}16 \\
67\end{array}$ & $\begin{array}{l}7 \\
70 \\
\end{array}$ & $\begin{array}{l}10 \\
67\end{array}$ & $\begin{array}{c}5 \\
56 \\
\end{array}$ & $\begin{array}{c}7 \\
78 \\
\end{array}$ & $\begin{array}{l}13 \\
87\end{array}$ & $\begin{array}{l}47 \\
67\end{array}$ & $\begin{array}{l}39 \\
71\end{array}$ & $\begin{array}{l}41 \\
66\end{array}$ & $\begin{array}{l}36 \\
63\end{array}$ & $\begin{array}{l}38 \\
68 \\
\end{array}$ & $\begin{array}{l}44 \\
70\end{array}$ \\
\hline $\begin{array}{l}\text { Maj.-Min. } \\
\text { District }\end{array}$ & $\begin{array}{l}29 \\
67 \\
\end{array}$ & $\begin{array}{l}30 \\
67 \\
\end{array}$ & $\begin{array}{l}31 \\
66\end{array}$ & $\begin{array}{l}37 \\
77 \\
\end{array}$ & $\begin{array}{l}30 \\
64 \\
\end{array}$ & $\begin{array}{l}32 \\
67 \\
\end{array}$ & $\begin{array}{l}12 \\
46 \\
\end{array}$ & $\begin{array}{r}4 \\
40 \\
\end{array}$ & $\begin{array}{r}5 \\
33 \\
\end{array}$ & $\begin{array}{r}3 \\
33 \\
\end{array}$ & $\begin{array}{c}4 \\
44 \\
\end{array}$ & $\begin{array}{c}9 \\
60 \\
\end{array}$ & $\begin{array}{l}41 \\
60\end{array}$ & $\begin{array}{l}34 \\
62 \\
\end{array}$ & $\begin{array}{l}36 \\
58 \\
\end{array}$ & $\begin{array}{l}40 \\
70 \\
\end{array}$ & $\begin{array}{l}34 \\
61\end{array}$ & $\begin{array}{l}41 \\
65 \\
\end{array}$ \\
\hline $\begin{array}{l}\text { Maj.-White } \\
\text { District }\end{array}$ & $\begin{array}{l}17 \\
33\end{array}$ & $\begin{array}{l}15 \\
33\end{array}$ & $\begin{array}{l}16 \\
34\end{array}$ & $\begin{array}{l}11 \\
23\end{array}$ & $\begin{array}{l}17 \\
36\end{array}$ & $\begin{array}{l}16 \\
33\end{array}$ & $\begin{array}{l}12 \\
54\end{array}$ & $\begin{array}{c}6 \\
60\end{array}$ & $\begin{array}{l}10 \\
67\end{array}$ & $\begin{array}{l}6 \\
67\end{array}$ & $\begin{array}{c}5 \\
56\end{array}$ & $\begin{array}{c}6 \\
40\end{array}$ & $\begin{array}{l}29 \\
40\end{array}$ & $\begin{array}{l}21 \\
38\end{array}$ & $\begin{array}{l}26 \\
42\end{array}$ & $\begin{array}{l}17 \\
30\end{array}$ & $\begin{array}{l}22 \\
39\end{array}$ & $\begin{array}{l}22 \\
35\end{array}$ \\
\hline $\begin{array}{l}\text { White } \\
\text { Opposition }\end{array}$ & $\begin{array}{l}22 \\
48 \\
\end{array}$ & $\begin{array}{l}30 \\
64 \\
\end{array}$ & $\begin{array}{l}22 \\
47 \\
\end{array}$ & $\begin{array}{l}23 \\
48 \\
\end{array}$ & $\begin{array}{l}25 \\
53 \\
\end{array}$ & $\begin{array}{l}38 \\
79 \\
\end{array}$ & $\begin{array}{r}8 \\
33 \\
\end{array}$ & $\begin{array}{r}5 \\
50 \\
\end{array}$ & $\begin{array}{r}6 \\
40 \\
\end{array}$ & $\begin{array}{r}3 \\
33 \\
\end{array}$ & $\begin{array}{r}2 \\
22 \\
\end{array}$ & $\begin{array}{r}5 \\
33 \\
\end{array}$ & $\begin{array}{r}30 \\
43 \\
\end{array}$ & $\begin{array}{l}35 \\
64 \\
\end{array}$ & $\begin{array}{l}28 \\
45 \\
\end{array}$ & $\begin{array}{l}26 \\
46 \\
\end{array}$ & $\begin{array}{l}27 \\
48 \\
\end{array}$ & $\begin{array}{l}44 \\
70 \\
\end{array}$ \\
\hline $\begin{array}{l}\text { Black } \\
\text { Opposition }\end{array}$ & $\begin{array}{l}16 \\
35 \\
\end{array}$ & $\begin{array}{c}5 \\
11 \\
\end{array}$ & $\begin{array}{c}9 \\
19 \\
\end{array}$ & $\begin{array}{c}8 \\
17 \\
\end{array}$ & $\begin{array}{c}7 \\
15 \\
\end{array}$ & $\begin{array}{c}9 \\
19 \\
\end{array}$ & $\begin{array}{l}16 \\
67 \\
\end{array}$ & $\begin{array}{c}5 \\
50 \\
\end{array}$ & $\begin{array}{c}9 \\
60 \\
\end{array}$ & $\begin{array}{l}6 \\
67 \\
\end{array}$ & $\begin{array}{c}7 \\
78 \\
\end{array}$ & $\begin{array}{c}9 \\
60 \\
\end{array}$ & $\begin{array}{l}32 \\
46 \\
\end{array}$ & $\begin{array}{l}10 \\
18 \\
\end{array}$ & $\begin{array}{l}18 \\
29 \\
\end{array}$ & $\begin{array}{l}14 \\
26 \\
\end{array}$ & $\begin{array}{l}14 \\
25 \\
\end{array}$ & $\begin{array}{l}18 \\
29 \\
\end{array}$ \\
\hline $\begin{array}{l}\text { Unopposed } \\
*\end{array}$ & $\begin{array}{c}8 \\
17\end{array}$ & $\begin{array}{l}10 \\
22\end{array}$ & $\begin{array}{l}16 \\
34\end{array}$ & $\begin{array}{l}17 \\
35\end{array}$ & $\begin{array}{l}15 \\
32\end{array}$ & $\begin{array}{l}1 \\
2\end{array}$ & $\begin{array}{l}0 \\
0\end{array}$ & $\begin{array}{l}0 \\
0\end{array}$ & $\begin{array}{l}0 \\
0\end{array}$ & $\begin{array}{l}0 \\
0\end{array}$ & $\begin{array}{l}0 \\
0\end{array}$ & $\begin{array}{l}1 \\
7\end{array}$ & $\begin{array}{c}8 \\
11\end{array}$ & $\begin{array}{l}10 \\
18\end{array}$ & $\begin{array}{l}16 \\
26\end{array}$ & $\begin{array}{l}17 \\
28\end{array}$ & $\begin{array}{l}15 \\
27\end{array}$ & $\begin{array}{c}21 \\
1\end{array}$ \\
\hline $\begin{array}{l}\text { House } \\
\text { Candidates }\end{array}$ & $\begin{array}{l}45 \\
98 \\
\end{array}$ & $\begin{array}{l}44 \\
98 \\
\end{array}$ & $\begin{array}{l}45 \\
96 \\
\end{array}$ & $\begin{array}{l}45 \\
96 \\
\end{array}$ & $\begin{array}{l}45 \\
93 \\
\end{array}$ & $\begin{array}{l}45 \\
94 \\
\end{array}$ & $\begin{array}{l}23 \\
96 \\
\end{array}$ & $\begin{array}{c}10 \\
100 \\
\end{array}$ & $\begin{array}{l}13 \\
87 \\
\end{array}$ & $\begin{array}{c}8 \\
89 \\
\end{array}$ & $\begin{array}{c}9 \\
100 \\
\end{array}$ & $\begin{array}{c}15 \\
100 \\
\end{array}$ & $\begin{array}{l}68 \\
97 \\
\end{array}$ & $\begin{array}{l}54 \\
98 \\
\end{array}$ & $\begin{array}{l}58 \\
94 \\
\end{array}$ & $\begin{array}{l}54 \\
95 \\
\end{array}$ & $\begin{array}{l}54 \\
96 \\
\end{array}$ & $\begin{array}{l}60 \\
95 \\
\end{array}$ \\
\hline $\begin{array}{l}\text { Senate } \\
\text { Candidates }\end{array}$ & $\begin{array}{l}1 \\
2 \\
\end{array}$ & $\begin{array}{l}1 \\
2 \\
\end{array}$ & $\begin{array}{l}2 \\
4 \\
\end{array}$ & $\begin{array}{l}2 \\
4 \\
\end{array}$ & $\begin{array}{l}2 \\
4 \\
\end{array}$ & $\begin{array}{l}3 \\
6 \\
\end{array}$ & $\begin{array}{l}1 \\
4 \\
\end{array}$ & $\begin{array}{l}0 \\
0\end{array}$ & $\begin{array}{c}2 \\
13 \\
\end{array}$ & $\begin{array}{c}1 \\
11 \\
\end{array}$ & $\begin{array}{l}0 \\
0\end{array}$ & $\begin{array}{l}0 \\
0\end{array}$ & $\begin{array}{l}2 \\
3 \\
\end{array}$ & $\begin{array}{l}1 \\
2\end{array}$ & $\begin{array}{l}4 \\
6 \\
\end{array}$ & $\begin{array}{l}3 \\
5 \\
\end{array}$ & $\begin{array}{l}2 \\
4 \\
\end{array}$ & $\begin{array}{l}3 \\
5\end{array}$ \\
\hline
\end{tabular}


the previous redistricting, the Republicans controlled the entire process in Virginia. Two other things are working in the Democrats' favor: most of the population growth in the country is from minority groups and the Democrats control the Department of Justice (unlike post-2000).

\section{The Congressional Black Caucus in the 112th Congress}

Except for the two newly elected black Republicans, all CBC members are Democrats, and since the Democrats lost control of the US House, the loss of CBC status and power is enormous. The CBC is losing three full committee chairmanships, and more than a dozen subcommittee chairmanships in the 112th Congress; and of course with these losses go concomitant losses in staff positions. While the black membership in the U.S. House is at an all time high, black influence there has been truly diminished. As has happened in the past when the Democrats lost the majority in the House, CBC members are going to have to work with the White House and supportive US Senators to advance the legislative priorities.

Table 5. Statistical Profile of Results for Black Major Party Federal Nominees, 2010

\begin{tabular}{|c|c|c|c|c|c|c|}
\hline & \multicolumn{2}{|c|}{ Democrats } & \multicolumn{2}{|c|}{ Republicans } & \multicolumn{2}{|c|}{ Total } \\
\hline & $\begin{array}{c}\text { Won } \\
(\mathrm{N}) \\
(\%)\end{array}$ & $\begin{array}{l}\text { Lost } \\
(\mathrm{N}) \\
(\%)\end{array}$ & $\begin{array}{l}\text { Won } \\
(\mathrm{N}) \\
(\%)\end{array}$ & $\begin{array}{l}\text { Lost } \\
(\mathrm{N}) \\
(\%)\end{array}$ & $\begin{array}{l}\text { Won } \\
(\mathrm{N}) \\
(\%)\end{array}$ & $\begin{array}{l}\text { Lost } \\
(\mathrm{N}) \\
(\%)\end{array}$ \\
\hline Total & 42 & 6 & 2 & 13 & 44 & 19 \\
\hline Incumbents & 37 & 0 & - & - & 37 & 0 \\
\hline Challengers/Open Seats & 5 & 6 & 2 & 13 & 7 & 19 \\
\hline Women & 15 & 2 & 0 & 2 & 15 & 4 \\
\hline Men & 27 & 4 & 2 & 11 & 29 & 15 \\
\hline Majority-Minority District & 32 & 0 & 0 & 9 & 32 & 9 \\
\hline Majority White District & 10 & 6 & 2 & 4 & 12 & 10 \\
\hline White Opposition & 32 & 6 & 1 & 4 & 33 & 10 \\
\hline Black Opposition & 9 & 0 & 0 & 9 & 9 & 9 \\
\hline Unopposed $^{\mathrm{H}}$ & 1 & 0 & 1 & 0 & 2 & 0 \\
\hline House Candidates & 42 & 3 & 2 & 13 & 44 & 16 \\
\hline Senate Candidates & 0 & 3 & 0 & 0 & 0 & 3 \\
\hline Average Vote & $\begin{array}{c}N=42 \\
72.6\end{array}$ & $\begin{array}{c}N=6 \\
33.7\end{array}$ & $\begin{array}{c}N=2 \\
54.0\end{array}$ & $\begin{array}{c}N=13 \\
27.8\end{array}$ & $\begin{array}{c}N=44 \\
72.2\end{array}$ & $\begin{array}{c}N=19 \\
29.8\end{array}$ \\
\hline
\end{tabular}

$\mathrm{H}$ Unopposed or no major party opposition in general election Average vote is for candidates with opposition. Totals include two delegate races in D.C. and the American Virgin Islands. 


\begin{tabular}{|c|c|c|c|c|c|}
\hline \multicolumn{6}{|c|}{ U.S. House of Representatives } \\
\hline District & \begin{tabular}{|l} 
BVAP \\
$(\%)$
\end{tabular} & Democrat & $\begin{array}{l}\text { Dem } \\
\text { Vote } \\
(\%)\end{array}$ & $\begin{array}{l}\text { Rep } \\
\text { (Vote) }\end{array}$ & Republican \\
\hline $\mathrm{AL} 7$ & 57.8 & $>$ Terri Sewell & 72 & 28 & Carol Chamberlain \\
\hline AR 2 & 17.4 & Joyce Elliot & 38 & 58 & $\underline{\text { Tim Griffin }>}$ \\
\hline CA 9 & 24.5 & $>$ Barbara Lee' & 83 & 12 & Gerald Hashimoto \\
\hline $\mathrm{CA}_{33}$ & 29.6 & >Karen Bass & 86 & 14 & James Andion \\
\hline $\mathrm{CA}_{35}$ & 35.0 & >Maxine Water' & 79 & 21 & K. Bruce Borwn \\
\hline $\mathrm{CA}_{37}$ & 24.7 & Laura Richardson' & 69 & 23 & Star Parker \\
\hline $\mathrm{CO}_{7}$ & 5.4 & $\geq$ Ed Perlmutter $^{!}$ & 53 & 42 & Ryan Frazier \\
\hline D.C. & 55.7 & $>$ Eleanor Holmes Norton' & 90 & 90 & Marjorie Reilly Smith \\
\hline $\mathrm{FL}_{3}$ & 45.1 & $>$ Corrine Brown' & 63 & 63 & MichaelYost \\
\hline $\mathrm{FL} 17$ & 51.3 & $>$ Frederica Wilson & - & - & Unopposed \\
\hline $\mathrm{FL} 22$ & 24.6 & Ron Kleinl & 46 & 46 & Allen West> \\
\hline $\mathrm{FL} 23$ & 46.2 & $>$ Alcee Hastings $^{\prime}$ & 79 & 79 & Bernard Sansaricq \\
\hline $\mathrm{GA}_{2}$ & 40.9 & $>$ Sanford Bishop' & 51 & 51 & Mike Keown \\
\hline $\mathrm{GA}_{4}$ & 48.8 & >Hank Johnson' & 75 & 75 & Lisbeth Carter \\
\hline $\mathrm{GA}_{5}$ & 51.0 & >John Lewis' & 74 & 26 & Fenn Little \\
\hline $\mathrm{GA}_{13}$ & $37 \cdot 3$ & $>$ David Scott' & 70 & 30 & Mike Crane \\
\hline $\mathrm{IL}_{1}$ & 63.2 & >Bobby Rush' & 80 & 16 & Ray Wardingly \\
\hline IL 2 & 59.4 & >Jesse Jackson, Jr.' & 80 & 14 & Isaac Hayes> \\
\hline $\mathrm{IL} 7$ & 55.9 & >Danny K. Davis' & 81 & 16 & Mark Weiman \\
\hline IL 10 & 6.7 & Dan Seals & 49 & 51 & Bob Dold> \\
\hline $\mathrm{IN}_{7}$ & 26.7 & >Andre Carson' & 59 & 38 & Marvin Scott \\
\hline LA 2 & $59 \cdot 3$ & $>$ Cedrick Richmond & 65 & 33 & Anh "Joseph" Cao' \\
\hline $\mathrm{MD}_{4}$ & $55 \cdot 3$ & >Donna Edwards' & 84 & 16 & Robert Broadus \\
\hline $\mathrm{MD} 5$ & 28.7 & $>$ Steny Hoyer $^{\prime}$ & 64 & 35 & Charles Lollar \\
\hline $\mathrm{MD}_{7}$ & 57.0 & $>$ Elijah Cummings' & 75 & 23 & Frank Mirabile \\
\hline $\mathrm{Ml} 13$ & 57.9 & $>$ Hansen Clarke & 79 & 19 & John Hauler \\
\hline $\mathrm{Ml} 14$ & 58.9 & >John Conyers' & 77 & 20 & Don Ukrainec \\
\hline $\mathrm{MN}_{5}$ & 10.2 & $>$ Keith Ellisonl (DFL) & 68 & 24 & $\underline{\text { Joel Demos }}$ \\
\hline $\mathrm{MS}_{2}$ & 58.9 & >Bennie Thompson' & 62 & 37 & Bill Marcy \\
\hline $\mathrm{MO}_{1}$ & 45.8 & $>$ William Clay, Jr.' & 74 & 24 & Robyn Hamlin \\
\hline $\mathrm{MO}_{5}$ & 21.8 & >Emanuel Cleaver' & 53 & 44 & Jacob Turk \\
\hline $\mathrm{NJ} 10$ & $54 \cdot 3$ & >Donald Payne' & 85 & 13 & Michael Alonzo \\
\hline NY 6 & 51.1 & $>$ Gregory Meeks' & 85 & 15 & AsherTaub \\
\hline NY 10 & 60.0 & $>$ Edolphus Towns' & 91 & 7 & Diana Muniz \\
\hline NY 11 & 56.8 & >Yvette Clarke' & 90 & 10 & Hugh Carr \\
\hline NY 15 & 30.5 & $>$ Charles Rangel' & 80 & 10 & Michel Faulkner \\
\hline $\mathrm{NC}_{1}$ & 47.6 & $>$ George K. Butterfield, Jr.' & 59 & 41 & Ashley Woolard \\
\hline $\mathrm{NC} 12$ & 41.9 & $>$ Mel Wattl & 64 & 34 & Scott Cumbie \\
\hline $\mathrm{NC} 13$ & 25.2 & $>$ Brad Miller & 55 & 45 & Bill Randall \\
\hline $\mathrm{OH} 11$ & 51.6 & $>$ Marcia Fudge' & 82 & 18 & Matt Brakey \\
\hline $\mathrm{PA} 2$ & 56.5 & $>$ Chaka Fattah' & 89 & 11 & Rick Hellberg \\
\hline $\mathrm{SC}_{1}$ & 18.6 & Unopposed & - & - & Tim Scott> \\
\hline SC 6 & $53 \cdot 5$ & >James Clyburn' & 63 & 36 & $\underline{\text { Jim Pratt }}$ \\
\hline
\end{tabular}




\begin{tabular}{|c|c|c|c|c|c|}
\hline \multicolumn{6}{|c|}{ U.S. House of Representatives } \\
\hline District & $\begin{array}{l}\text { BVAP } \\
(\%)\end{array}$ & Democrat & $\begin{array}{l}\text { Dem } \\
\text { Vote } \\
(\%)\end{array}$ & $\begin{array}{l}\text { Rep } \\
\text { (Vote) }\end{array}$ & Republican \\
\hline TN 9 & 55.1 & $>$ Steve Cohen' & 74 & 25 & Charlotte Bergmann \\
\hline TX 9 & 36.5 & >Al Green' & 76 & 23 & Steve Mueller \\
\hline $\mathrm{TX}_{18}$ & 40.3 & >Sheila J. Lee' & 70 & 27 & $\underline{\text { John Faulk }}$ \\
\hline TX 22 & 9.1 & Kesha Rogers & 28 & 69 & Pete Olson \\
\hline $\mathrm{TX}_{30}$ & 41.0 & >Eddie B. Johnson' & 76 & 22 & Stephen Broden \\
\hline $\mathrm{VA}_{3}$ & 52.7 & $>$ Robert Scott' $^{\prime}$ & 70 & 27 & Chuck Smith \\
\hline V.I. & 61.4 & >Donna Cristensen' & $\mathrm{n} / \mathrm{a}$ & $\mathrm{n} / \mathrm{a}$ & Vince Danet \\
\hline WI-4 & 27.8 & $>$ Gwen Moore' & 69 & 30 & Dan Sebring \\
\hline \multicolumn{6}{|c|}{ U.S Senate } \\
\hline State & \begin{tabular}{|l} 
BVAP \\
$(\%)$ \\
\end{tabular} & Democrat-\% & \multicolumn{2}{|c|}{$\begin{array}{l}\text { Independent } \\
\text {-\% Vote }\end{array}$} & Republican-\% Vote \\
\hline $\mathrm{FL}$ & 14.7 & Kendrick Meek-20\% & \multicolumn{2}{|c|}{ Charles Christ-30\% } & .MArio Rubio-49\% \\
\hline GA & 29.2 & Michael Thurmond-39\% & \multicolumn{2}{|c|}{$\mathrm{n} / \mathrm{a}$} & Johnny Isaacson'-58\% \\
\hline SC & 26.0 & Alvin Greene-28\% & \multicolumn{2}{|c|}{$\mathrm{n} / \mathrm{a}$} & Jim DeMint'-62\% \\
\hline
\end{tabular}




\section{William G. Allen in Britain}

\section{By Marika Sherwood}

William Allen was among the many free African Americans who made their way to the United Kingdom in the first half of the nineteenth century to escape conditions in the US. He was probably best educated, and one of the few who settled in England permanently. Many African Americans - especially the temporary residents, the visiting lecturers, - found a superficial acceptance in the UK, but William Allen's life demonstrates that this was only on the surface; and that the situation for Blacks deteriorated as the century advanced. A man with his education, and teaching as well as writing experience, should not have found it difficult to earn a living. That he did, and that he and his family probably spent many years in penury, demonstrates the superficiality of English politeness to people with a darker skin.

\section{Early life in the North America}

Born in about 1820, William was the son of a free 'mulatto' mother and a Welshman. His parents died when he was young and he was adopted by a 'relatively well-to-do' Black family. Through contacts with Federal troops stationed near his home following Nat Turner's Revolt, he learned some French and German. An excellent scholar, his schoolmaster at the local elementary school sought the financial support of wealthy abolitionist Gerrit Smith to finance William's further education.

With this support, William enrolled at the Oneida Institute in New York state. This multi-racial school was a hotbed of abolitionist activity. On graduation in 1841 he taught primary or 'common school' in Troy, NY and co-edited abolitionist Henry Highland Garnet's National Watchman and participated in the Black National Convention movement. In 1847 he moved to Boston, began a clerkship in a legal firm andgave lectures as part of the anti-slavery anti-racial prejudice movement. To aid his audiences, he published a booklet of speeches by famous Blacks to which he added biographical sketches and an introduction. He also served as the secretary of the Boston Coloured Citizens Association.

Probably because of his political enthusiasms, Allen left Boston to become a lecturer of Greek Languages and Literature, and 'Belles Lettres' at the Central College, McGrawville, NY. Founded in 1849 as an inter-racial, co-educational, anti-slavery college, the College also advocated women's rights. Though devoted to his teaching, Allen found time to continue his political activism. His speech on 'Orators and Orations' was published in two abolitionist weeklies. At a meeting of the School's Dialexian Society on 22 June 1852 he attacked the neutral stance on slavery taken by Lajos Kossuth, the visiting exiled Hungarian freedom fighter touring the US to seek support for his cause. He became a correspondent in Frederick Douglass' Paper, which, for example, published his thoughts on Uncle Tom, the recently published book by Harriet Beecher Stowe. His commentary concludes with: 'Let us take this to our hearts, at least, that slavery is a national sin, and nations are not fixed facts, but are continually, though maybe slowly, passing away'.

In 1853 Allen's comfortable life came to an abrupt halt. While on a lecture tour in upstate New York, he had met Mary, the daughter of Rev. King, an abolitionist, who was about to join the College. They fell in love and announced their intention to marry. While the Revd. King did not object, the rest of the family did, as did the local villagers. Mary had to literally run for her life, as did William. With the aid of friends they married in New York on 30 March 1853. In a letter to Gerrit Smith from Boston, dated 9 April, Allen advises his benefactor that he and his wife are leaving that day on the 'packet ship Daniel Webster for Liverpool... Mary is in excellent health and spirits and begs to be remembered to yourself and Elder Stowe with most affectionate regards'. Allen signs the letter 'in haste, but ever gratefully.' Evidently Gerrit Smith had continued to support Allen, and now also his wife. 


\section{A new life in Britain, $1853-1859$}

William and his wife Mary arrived with introductions to some of the abolitionists in Britain. Gerrit Smith had written to veteran anti-slavery campaigner Joseph Sturge that he took 'great pleasure in introducing to you my much esteemed friend, Professor Wm. G. Allen. I know him well, and know him to be a man of great mental and moral worth, I trust, in his visit to England, he will be both useful and happy'. But Sturge was not hopeful of the Allens' being able to secure a living in Britain, as he told Gerrit Smith:

In the Spring of last year William G Allen called upon me with a letter of introduction from thee and I afterwards saw both him and his wife living in London. He told me that he intended to remain in England and to lecture on literary and philosophical subjects and I afterwards found from a circular in which he had introduced a short paragraph from thy letter and a few lines from me.... [l]f I had known that he was dependent upon his lectures I should have I think considered his coming here an unwise step and encouraged his early return... but I gave him a note to one of the Secretaries of the AntiSlavery Society in London that he might have some advise with them... I [received] the enclosed note and my object in sending it to thee is that thou mayest see the position he is in, and if thou has any influence with his friends and relatives in the United States I think it would be a kindness to him and his wife if they could encourage him to return...as I expect his reliance upon the proceeds from lecturing here and an agency to the Ladies Anti-Slavery Society shd not be realized. I think he is a well-meaning man of good abilities...but...I believe some part of what he got last winter arose from a benevolent feeling towards him and his wife.

\section{(Unfortunately the enclosed letter by Allen has not been preserved.)}

The Anti-Slavery Society had indeed taken Allen under its wing. He was introduced at the Society's Annual General meeting held in June 1853. The Anti-Slavery Advocate in its July issue described him as a 'gentleman of colour...pleasing, with an intelligent countenance.' (p.76) The story of the Allens' marriage was recounted and it was announced that Allen intended to earn his living by lecturing. We learn more of the Anti-Slavery Society's meeting at Exeter Hall from a letter in Frederick Douglass' Paper of 10 June 1853 by William Wells Brown, the African American anti-slavery activist then touring Britain. The meeting had attracted some 5,000 people, many of whom had come, Brown believes, to see Harriet Beecher Stowe. (Her book, Uncle Tom's Cabin had become a bestseller.) The packed meeting had been chaired by the Earl of Shaftesbury; Mrs Stowe arrived escorted by the Duchess of Sutherland. As the customs of the time did not permit women to speak from platforms, Mrs Stowe sat in the audience; Brown found her husband's speech disappointing and he despairs 'of anything being done by clergymen'. Perhaps he meant White ones, as he deems the speech of the African American Rev. Samuel Ward as the best of the evening. Brown notes that 'Professor Wm. G. Allen and lady and Wm. and Ellen Craft' are in the audience, as well as White American abolitionists.

William Lloyd Garrison, another leading American abolitionist, had introduced Allen to British chartist and abolition campaigner, the Wesleyan George Thompson. Allen described his and his wife's visits to Thompson's home in a letter published in The Liberator on 22 July 1853 . In this he also depicts their experiences:

'Old England' is a wonderful country... The English people - there is nobility in their hearts and dignity in their bearing... [l]n Englishmen [there is] the entire absence of prejudice against color. Here the colored man feels himself among friends; people who when they treat him well, do it not in the patronising spirit, but in the spirit rightly appreciative of the doctrine of human equality. Colour claims no precedence over character.

[T] he marriage of two respectable persons, one of whom should be white and the other colored, passes as a matter of course in England... This state of things, of course, evinces that prejudice against color is entirely a local feeling, generated by slavery. (p.116) 
In this letter Allen also mentions that he and the Rev. Samuel Ward, the visiting Black abolitionist, had been invited to a party given by the Prussian Ambassador at his residence in Hyde Park. He had spent time with visiting American abolitionists, and with the Unitarian abolitionist, James Estlin. Mrs Stowe, the Rev. Ward and William Wells Brown had been drawing large audiences to their lectures, Allen recounts. But all was perhaps not well between Allen and Ward. In a letter to Gerrit Smith, Allen writes that:

'Ward is very successful in his mission. I can do nothing at present for the College. The missions of Mrs Stowe and Ward were cognate of mine and have as a matter of course taken precedence... Mr Sturge and other such men, for the above and additional reasons, advised me not to attempt the agency.'

While we do not learn the nature of this 'agency', it is clear that Allen is being pushed into the background by the presence of Harriet Beecher Stowe, a (White) celebrity.

While waiting for the end of the lecture tours of Ward and Stowe, Allen wrote The American Prejudice Against Color: an authentic narrative, showing how easily the nation went into uproar, which was published simultaneously in London, Edinburgh \& Dublin in 1853. It tells his history as a 'quadroon' in the US and of how he met Mary King, a student in the college where he was teaching. Her father and sister gave them their blessing, but her brothers and step-mother were virulently opposed to their engagement. They stirred up public resentment, which escalated first into public denigration a 'murderous outrage'- in the press; and then in the gathering of a 'band of several hundred armed men...to kill or drive out a single individual' - ie himself.(pp.69-70) He fled, as had Mary.

It is not known how successful this small book was; how much it aided the Allens; or whether it was sold at the meetings Allen was shortly to begin addressing.

Though initially the Allens stayed close to central London, by January 1854 they were living in suburban - and much cheaper - Clapham. It is possible that they moved there with the aid of George Thompson, whose recommendation, printed in the Preface of Allen's book, is from Clapham. Dated 25 August 1853, Thompson hopes that Allen will 'meet with ample encouragement from the friends of abolition throughout the United Kingdom, to whose sympathy and kindness I would earnestly recommend you and still more your heroic and most estimable lady'.

In Clapham, Allen wrote in a letter printed in The Liberator in July 1853, that they lived 'in a sweet little cottage and my wife is as happy as she can be...'

'The dear friends whom we have made in this country have been exceedingly kind... [We] like London... companionable - prejudice against color being a thing entirely unknown in the glorious isle.'

He mentions that they had been invited to the 'house of a gentleman, a man of wealth - retired from business.' The children of their host were at the gathering; the host's son introduced the Allens to his wife, 'a bona-fide colored lady'. This perspective, that there was an 'entire absence of prejudice against color.... Color claims no precedent over character' must have been a great relief to the Allens. But this positive assessment of Britain did not last long.

In this letter Allen also relates that he had been

'spending a few weeks in the provinces. My lectures were enthusiastically received, and the warmest welcomes were extended to us. I say us - for although my wife was not with me, yet the resolutions passed in the meetings invariably included both. At nearly every meeting either the mayor 
of the city or some member of parliament presided.'

Allen was also broadening his interests. In this same letter to Gerrit Smith he states that

'the subject of Penal Reformatory Schools is now beginning to excite much interest in this country and I have embarked in the agitation thereof. I am countenanced and greatly aided in this matter by the Honorable Lady Byron.'

Allen is clearly very happy to have found a 'reliable vocation' (ie paid employment) which 'renders me practically useful to the British public, and at the same time elevates me into a position at once respectable and influential.' This work, which might have included also lecturing for the moral reformatory school movement, did not, he noted 'debar [him] from lecturing upon slavery'. He also hoped, before returning to America, to spend 'a year or two in study in one of the German universities'.

But all did not go well with Lady Byron. We do not know what happened; all we have is a somewhat misogynistic letter from Allen to Alexis Chamerovzow, the Secretary of the Anti-Slavery Society dated 11 July, apologising for not having repaid the 115.5 so he owed. This was due to his

'misfortune to get entangled in business matters not with men but with women. \{unreadable] has undoubtedly told you about that affair with Lady Byron. I am very sorry but do try to think of me

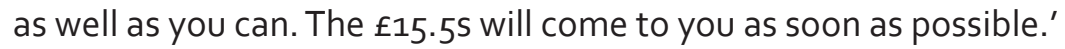

Allen apparently commenced his lecture in the northern counties, beginning in Leeds in November 1853. The Leeds Anti-Slavery Society advertised the lectures in the Leeds Intelligencer of 26 November:

PROFESSOR ALLEN, a coloured Gentleman, from America, to Deliver a course of THREE

LECTURES in the stock Exchange Room, Albion Street, on the following subjects:-

FIRST LECTURE, Tuesday, November 29th, 1853, on 'American Slavery, and prejudice against

Colour.' The Mayor in the Chair.

SECOND LECTURE, Thursday, December 1st, 'The Social and Political condition of the Free

Coloured People in the Northern States of America.' The Rev. Wm. Sinclair, M.A. in the Chair.

THIRD LECTURE, Monday, December 5th, 'The Probable Destiny of the Coloured Race.'

Edwd. Baines, Esq. In the Chair.

Admission to each Lecture, 3d. Reserved Seats, 6d.

Doors open at Seven to commence at Half-past.

The report of his talks in the Leeds Intelligencer tell us much about attitudes towards Black people at the time, as it implies that Allen's accomplishments were at least partly due to his White heritage:

The professor, who is a mulatto, while possessing many of the characteristics of the negro race, has yet much that proclaims the admixture of the blood of the white man, and is gifted with a full, sonorous voice, perfectly correct enunciation, and an easy flowing style.

At the final meeting Edward Baines, who chaired, proclaimed his response to Allen and other Blacks of his class:

'in England [we] receive gentlemen of colour, who come here with testimonials of character showing that they are gentlemen, scholars and Christians....and receive them in our houses and mingle with them at public meetings and treat them as in every whit on a perfect equality with ourselves.'

How true was this in the early 1850 ? Or was it only those involved in anti-slavery work who felt this way? What of 'gentlemen of colour' without testimonials, or the more numerous 'non-gentlemen' how did Baines and his peers respond to them? There is insufficient research in the UK on the lives of 
Black residents in the Victorian era. But it must be noted that some ten years later there was a proslavery lobby in England at the time of the Civil War in the US and Allen himself by then had become critical of British attitudes.

In his first Leeds lecture Allen fully described life under slavery for both women and men, and argued that life for free Blacks was very problematic not only because of restrictive laws, but because 'slavery had led to prejudice against colour'. He named a 'galaxy of geniuses who had been of African blood, to prove that where the opportunity was given there was no inferiority exhibited by the men of African descent'. In the US prejudice was diminishing, due to 'the American people feeling the force of a world's indignation'. Mrs Stowe had helped ignite this, while Douglass and the rise of other Blacks demonstrated that 'now has the star of our hope risen above the horizon'. He 'called upon the people of England to aid in the good work of destroying slavery in the United States.'

The second lecture was devoted to 'the free coloured people of the northern states of America'. He outlined the degrading and highly restrictive laws against free Blacks, the threats of re-enslavement, and the protests mounted against these by African Americans and their supporters. Given half a chance, Blacks could and did succeed - for example, Dr Smith 'who obtained his diploma at the University of Glasgow'. The Rev. W. Sinclair, who had chaired the session added that 'he could not but think the Christian church had fallen short in this respect: for if the churches of America had spoken out as they should have done, the result would have been different.'

In his third lecture, 'The Destiny of the Coloured Race', Allen displayed the prevalent ignorance of the history of Africa and its civilisations:

The future history of the African race would not be marked by the same degree of grandeur and glory which was destined to mark the history of Europeans. The African developed in his nature more of the moral than the purely intellectual superiority; and in his social and religious tendencies he might safely be classed at the head of the races... Then again the African had a decided facility for music...and was also poetical, extremely so... [T] he traits which the African exhibited in a state of barbarism he would exhibit, but in a greater perfection, when developed.

Allen then went on to deal with the future of African Americans, who would all, eventually, be emancipated; this would require 'agitation, not only in America but in this country especially'. Being returned to Africa was out of the question as Blacks were 'getting gradually Anglo-Saxonised' and such mixed-race people could not possibly be forced to move to Africa. He was opposed to the proposals of the Colonization Society, for the most prescient of reasons: it wanted to

'get the free coloured people out of America to Liberia [so that] the country may be developed in order that its resources might be poured into the lap of America'.

Asked if the freed slaves would continue 'their present occupations', in a long and tactful response Allen replied that

'all the slaves would desire, if paid for their labour, to remain [in America]. Of course, if the present oppressive spirit of the slaveholder continued, he could not tell what the result would be...'

Allen concluded by stating that

'since he had been in England he had found friends and not enemies, and learnt that in this country they respected a man for his worth, if he had any, and not according to the colour of his skin'.

At the end of the series, a resolution was passed expressing 'abhorrence at the whole system of 
slavery (and) prejudice'; and it was affirmed that William and his 'truly heroic wife have a large claim on our sympathy'.

Allen's next stop was the Mechanics Institute at Bradford and then Newcastle and South Shields.

The still-birth of their first child found Allen rushing back to London. Mary recovered sufficiently for William to be back on the road by May 1854, to lecture in Halifax and Edinburgh, at Dr. French's Church. It is possible that it was at least partly due to Allen's two lectures that the Edinburgh AntiSlavery Society was formed a couple of months later.

Allen was in London for the Anti-Slavery Society Annual meeting; this time not as a member of the audience, but sitting on the platform. In his address he concentrated on the extension of slavery in the US to Nebraska, and demanded that 'slavery should be swept away entirely'. Black Americans were constantly belittled by Whites, he said, but the 'coloured people of the Northern States presented themselves to the world in an attitude which claimed its respect and admiration'.

The December 1854 Anti-Slavery Advocate noted that Professor Allen had been lecturing in the London areas of Deptford, St John's Wood, Hackney, Sydenham, Southwark and Harrow; also in Bury, Manchester, Miles Platting, Harpenley and Pendleton. 'Many are interested in his lecture on the History, Literature and the Destiny of the African Race. In print he will enter more fully into the subject than is possible in two lectures.'

Is it possible that in his travels Allen had met Richard Webb, the Advocate's publisher? Certainly it seems that he intended to publish an extended version of his lectures. Sadly, he seems not to have been able to accomplish this.

In January 1855 the Allens returned to a more central London location. Had they also stayed at Mr. Thompson's, 11 Union Grove, Wandsworth Road, where Allen asked the Anti-Slavery Society to forward for his mail? 'Clapham had been too far out of town,' he wrote to Louis Chamerovzow, and they not only wanted 'a more central location' but also 'cheaper lodgings'. Yes, he would be happy to lecture in Camberwell.

Some incomplete correspondence indicates that Allen still had not repaid all his debt.

Clearly life was proving problematic for the Allens. While it is possible that Allen extended the range of his lectures, to earn a living as a peripatetic lecturer was clearly proving impossible. One problem he might have faced is indicated in the comment of Mr Baines, the chairman at Allen's final lecture in Leeds, who clearly had no idea of his own racism:

'[T] he last specimen of the African (Mr. Ward) who appeared in Leeds gave them such an overpowering sense of the energy of the blood that was within him. But what he was struck with in Professor Allen was the singularly calm, sedate and reflecting tone of his address.'

Perhaps such a quiet manner, especially in contrast with more flamboyant presentations, did not guarantee large and returning audiences. It is also likely that enthusiasm for the emancipation of African Americans was diminishing: even George Thompson, who had been a popular lecturer on the anti-slavery circuit, found in the mid 1850 s that 'there was not enough anti-slavery work in Britain to keep him in pocket money'. Certainly, if the admission fee charged in Leeds was the standard price, William and Mary could not have done more than scrape together an insufficient living. 
rejuvenate a flagging anti-slavery interest'. They arrived in Ireland in 1856, and stayed till about 1860. Did they go under the aegis, or at least at the suggestion of the Anti-Slavery Society? Did they go to give a series of talks and then decide to settle there? It is possible that the initial invitation had come from the relatively newly formed Cogler Anti-Slavery Society, at whose meeting in June 1855 Allen was the featured speaker. Had Allen received such a welcome there that he decided to move to Ireland? Or was it Richard Webb who suggested that the Allens should move to Ireland?

An itinerant life must have become increasingly difficult with the birth of children. And Allen needed to find some permanent occupation: after all, there are only so many places where the same person can give anti-slavery or even more broadly themed lectures! Especially when, as indicated previously, the lectures tended to be more academic than the fiery denunciations of others such as William Wells Brown or Douglass.

As William used Richard Webb's address for his mail, we can safely assume that the Allens must have been supported one way or another by Webb. Richard Webb was a Quaker, a printer and anti-slavery activist, who was also the founder/editor of the journal Anti-Slavery Advocate, published in Dublin. Webb was steeped in anti-slavery: he had corresponded with and hosted Frederick Douglass when he arrived in Dublin in 1845 and had then published Douglass' autobiography, with a second edition in 1846.

Certainly one way that Webb supported William and Mary and their children was by publishing The African poets, Horton and Placido, with an introduction by Professor Allen. How many copies were sold is not known. There is no trace, so far, of Allen being involved in the Irish equivalent of the education movements which had employed him in England. Nor do we have any comments by him on the horrific living conditions of the poor in Ireland. Did he perhaps feel he could not criticise English imperialism?

From an 1858 letter to Gerrit Smith, we learn that Allen was in Cork, without Mary. Written in response to correspondence from Smith, Allen explains that 'to support an increasing family and to maintain even a show of independence....absorb nearly the whole of my energies.' They had been in Dublin for two and a half years and Allen had been 'endeavouring to establish [himself] somewhat in the line of my old vocation, tuition in the higher departments of learning.' His earnings as a tutor were not meeting his 'family's wants and expenses', especially as his wife had been seriously ill. However, he was also lecturing, and was confident of 'even great success'. The Allens now had two children, Patrick aged two and a half, and Julia Maria, nine months old; they were expecting their third child.

Clearly Smith had asked him to return to America, but Allen said that he did not wish to expose his family to the racism there despite the fact that his initial enchantment with Britain was diminishing: writing of the 'Indian difficulties', he says that

'barbarously as the Indians have acted, the British have quite equalled them, and I, at least, can't help hoping that the upshot of the matter will be to teach this fiery white race that they are not to go all over creation robbing and slaying with impunity "the blacks", and that in the most contemptuous spirit; and all under the guise and in the name of Christianity and Civilization!'

I think this statement indicates that Allen's views - and his experiences - of the United Kingdom had changed. He now recognises the horrors of British imperialism as manifested in the putting down of the 1857 uprising in India. And he also acknowledges that when it comes to matters of empire, Indians and Africans face the same fate: they are all 'blacks' to the British. Had Allen by now also experienced what it could mean to be a 'Black' in the UK?

This was the second time that the city of Cork had offered hospitality to Black anti-slavery campaigners: Frederick Douglass had achieved great success there in 1845 . William wrote to Smith 
when he spent 'three months in the City of Cork', and

'was the guest of the Mayor of the City, who would hardly permit me to leave. They [the Mayor's family] became greatly attached to me and really shed tears on my leaving.'

John Francis Maguire, his host, was not only the mayor, but the founder and editor of the Cork Examiner, founder/ president of the Sick Poor Society, a nationalist, the author of a number of books including one advocating women's rights, and a future MP.

But the Allens were not doing well. Their daughter Harriet Aurilla was born sometime in 1858, and according to his letter to Gerrit Smith in May 1859, they were expecting another child. Allen was much concerned about the rapid increase in his family as he confessed to Smith that 'under our present circumstances [it] naturally occasions us considerable anxiety. We would like it if our future were more satisfactorily defined.' Though Allen told Smith that they were all in good health, he also says that Mary and the children were 'trying what value there is in a change of air, in a little country town, a few miles from Dublin.' They were lodging with a Mrs Heroris at Saul Street, Downpatrick.

The focus of the letter is William's need for help. Very reluctant to approach his patron, he encloses a note from Webb, attesting to the fact that he had done his best to 'be the architect of his own fortune'. Though he 'had labored hard and [they] had lived carefully and economically', his 'income [had] not kept pace with expenses'. Allen pleads for support to buy a house, as living in lodgings, he believes, is the reason that he had not been

'in a position to command that success in teaching that otherwise I could have done. We need therefore not a "home", but a place in which I can conduct my classes, etc.; and more suited to the manner of such things in this country.'

As this letter is written from Leamington Spa in England, was Allen again on a lecture tour? All we know is that he tells Smith that in four weeks he expects to 'return to Ireland and then take my family back to Dublin'. In a postscript regarding the death of 'our esteemed and beloved friend Joseph Sturge', whom he had seen a few days ago, Allen adds:

'the weak, the afflicted, the outcast, the prisoner, the oppressed, have lost a true friend... I have seen him twice since I have been in the country. I was never in Birmingham.'

Again, Allen reflects on the British attitudes to those of African descent:

there is a great need of colored men of the right sort in this country. There is none of the American prejudice against color here, but there is a far lower appreciation of the Negro and Colored races as such: the people of this country have never been accustomed to contemplate the African race in any other light than that of Slavery and consequently they never associate with the race the ideas of intellectual capacity, education and refinement. There's no wonder, of course, in all this, but it is certainly true that the people need to be educated up to a "higher level" with regard to the African race. I have perhaps been in a better position than any other colored man that has ever been in this country to judge rights of the people; and you may take it as my deliberate conviction that half a dozen colored men of the right stamp in this country would be a powerful anti-slavery instrumentality.... I feel satisfied that I have been enabled to do some good in this country for my race...

(What is tragic, though William Allen could not foresee this, is that though now there are many 'colored men of the right sort' in the UK, the general population is probably just as ignorant about Africa and as caustic about Africans' 'capacities' as they were in Allen's day, and notions about slavery still influence White attitudes.) 
We do not know why the Allens left Ireland. We can only presume that William had to confront the realities of not being able to earn enough to support his growing family there.

\section{London - c. 1860-1869}

There is no information regarding the Allens' decision to return to England, or when they returned, or how William earned a living for his ever-growing family.

That they were back in London in 1862, we learn from Allen giving the address at the farewell meeting for John Anderson on 22 December. Anderson, a fugitive slave, had arrived in England in 1861. He was welcomed by the Anti-Slavery Society at a meeting in Exeter Hall, where a support committee under Harper Twelvetrees was established. After encouraging Anderson to undertake a speaking tour, the committee decided to send him to be educated at the British Training Institute in Corby, Northants. The London Emancipation Society decided to help him emigrate to Liberia, where he could become 'independent and respectable'. At the meeting at Shirley's Hotel in Queen's Square, London, Allen said:

Africa could only become great again by the capacity of Africans to make her so. They ought not to complain of the blows they received, but gather strength to prevent them... Depend upon it, Africa has a glorious future before her... I rejoice in Liberia... [M] ust not forget to pay a passing tribute to Hayti. Here was a nation of Africans in the western world that had already illustrated the highest qualities of statesmanship and military genius.... The continent of Africa, its magnificent country, its in-numberable and splendid aboriginal races... It is on this account that I feel a peculiar interest in Liberia.

On 2 July 1863 the Anti-Slavery Society held a meeting, perhaps to advertise the Allen's future role; Harper Twelvetrees, philanthropist, manufacturer and abolitionist presided. The July 1863 AntiSlavery Reporter reported that

For ten years Professor Allen has struggled manfully to obtain an independent livelihood, gaining the confidence of all with whom he has been in contact. At length Mr Twelvetrees, whose benevolence ever assumes a practical character, combining with a few other persons, recently issued a brief appeal [for] $f 100$ for the purchase of the goodwill of a school... Called the Caledonian Training School. Professor Allen was installed on 19 June...[This] offered an excellent opening to launch Professor Allen on a career of usefulness, in an occupation most congenial to his mind and habits.'(p.154)

But the Caledonian School did not survive. We learn of its demise from a letter written on 21 April 1869, from Downham Road, Islington, which was not the address of their school. It is not in William's writing. Is it in Mary's? The letter enclosed a testimonial from Chamerovzow and asks the recipient to see the Anti-Slavery Reporter of June 1853 for

my history....and my autobiography, extensively circulated more especially among the Society of Friends... had purchased a school in Islington six years ago...150 pupils...conducted up to a recent period with much success... I have, I am happy to say, the entire confidence of both parents and pupils in this community... This very success has been the means of placing me in a very awkward, perplexed - even embarrassed position... Certain schoolmasters in this locality, not influenced by a spirit of honorable competiton, but by a spirit not usually supposed to exist among Englishmen, resolved to put down my school. They could not disperse my pupils nor draw them into their own schools, but they did succeed in inducing the landlord to compel me to put the school out of the house and this after I had gone to much expense in fitting up the house for school purposes. I have therefore been compelled to unite my school with a friendly Academy.

Allen goes on to explain that he had to do some repairs to his house after he had been evicted. 
The fees in his school, which had been 'small, and could not be otherwise for the character of the neighbourhood', had barely supported his wife and seven children, and paid the wage of an assistant teacher. Saving anything had not been possible, and what he had earned in the combined Academy had not covered his expenses. 'So Mrs Allen is proposing to establish a school for girls... She is a white person... She called upon a few Friends... and they advised us not to borrow but to endeavour to raise the amount required ( $₫ 150$ ) from a few friends.' They had managed to find suitable accommodation the previous August and now had thirty pupils and hoped to be 'entirely' self-supporting in about three months. But now they were behind with the $£ 9.15$ s quarterly rent which had been due in March: they had received some help towards this; could Miss Edwards also help?

His son Patrick, now aged fourteen, Allen adds, is working with Cassell, the well-known publisher, while his oldest daughter, aged 12, is assisting in the school.

Just how difficult it must have been to write such begging letters, and that his displacement in Islington might have been due to racism, is evident in the concluding paragraph of Allen's letter:

'I deplore the circumstances which have placed me at this disadvantage, but I cannot change my colour to please those who have thus placed me. And I would not do so if I could.'

Among the previous donors listed in this letter are three members of Parliament: C. W. Buxton, W.E. Forster and S. Morley.

Miss Edwards forwarded this letter to Chamerovzow, asking if the Allens were 'a suitable case for assistance.' Another recipient of this plea, Algernon Peckover of Wisbeach, also forwarded it to the Anti-Slavery Society Secretary for comment. Unfortunately the replies have not been preserved. But what is in the file is a printed, undated testimonial by Chamerovzow:

... have known the lady and her husband since their arrival in this country and can testify to their uniform, honorable and deserving conduct, as also to the independence which has characterised their endeavours to obtain a livelihood and to maintain and educate their young family.

That Allen did not give up lecturing, and that he was incensed by the rising tide of social Darwinism and eugenicism, we learn from a very brief statement in The Anthropological Review of April 1868:

In October last a coloured gentleman, Professor Allen, delivered two lectures on 'The Negro Race' in the Vestry Hall, Bow... In the course of his remarks he controverted the views put forth respecting the Negro by some members of the Anthropological society, which he stigmatised as 'foolish, not to say, blasphemous, theories'. The lectures were well attended and much applauded. (p.224)

How very sad that he had no effect on the Society - and how marvellous that those who attended supported his views! The Royal Anthropological Society had been established in 1863; its founder, James Hunt, believed in racial hierarchies and espoused eugenicist notions of racial degeneracy'.

\section{After 1869}

There is no information on the Allens' lives for the next ten years. Did Mrs Allen's attempt to run a school succeed? If it did, was that because she was a White woman? Did William have to avoid being seen in public with his wife in order not to jeopardise the school? But from the one extant letter from this period, it appears that the Allens again fell on hard times. On 8 April 1878 William Allen wrote to F.W. Chesson, who had replaced Chamerovzow at the Anti-Slavery Society: 
as he has responded $£_{5}$, a donation which, under the circumstances, was very useful... Has any more transpired regarding our friend from Barbados?

From this we learn not only that the family continued impoverished, but that William's involvement with the Anti-Slavery Society continued. What form this took is not revealed in the Society's papers.

How did the Allens survive between 1878 and 1887, our final glimpse of William's life? With the support of their children? In August of that year there is an account of a 'party of coloured singers, late of the Pennsylvania Jubilee band' who gave a concert in the Wesleyan Chapel in Strood, a small town in Kent, about 30 miles south-west of London.

'A cultured address on the characteristics of his race was given by Prof. Allen, who adds to pride of past negro history unbounded faith in their future influence of the world's events'.

There was another concert in the Methodist Hall: 'the in interval was admirably filled with the most excellent address from Professor Allen, on "The characteristics of the Negro race", who, in the course of his remarks, said that from a religious, social and humorous point of view the negro race had before them a grand and glorious future; that the black people were not created by the great God for th white man to shoot at; that, when the negro race were fully developed, fully civilised, they would exhibit to the eyes of the world, by their intensity of religious and social feelings, combined with their great intellectual power, what a man should be. He gave many illustrations which clinched the nails he had driven in. He said that "good humour was the juice of the brain", which the negroes had an abundance of, as evinced in their modes of salutation when they met each other. That, by and by, as the negro's mind developed, it should be shown that they had a glorious future'.

From Strood the singers moved further into rural Kent to give concerts in the town of Faversham and the village of Boughton. These were advertised as 'Slave Songs, Quaint Slave Melodies, and Camp Meeting Shouts, Addresses on Slave Life, \&c.' There is no mention of 'Prof. Allen' in the reports of the concerts, though presumably it was he who gave the 'addresses on slave life'.

As the concerts were free, and the 'Collections to defray Expenses' were to be shared with the Continental Sunday School Mission Fund, neither the singers nor the ageing William could have made much of a profit, even if their accommodation was free. How very sad, that this highly educated man, even now when compulsory education had been introduced, could not apparently find more regular and appropriate employment. Had the situation of Black people in Britain deteriorated even further? According to historian Douglas Lorimer,

'at least until the 1860s, Englishmen responded to the social rather than the physical attributes of black residents...they were prepared to accept black gentlemen as gentlemen...\{But] a change in attitude occurred... Blacks were identified by their race and history with servitude and savagery.'

The 1881 Census had found the William, described as 'Professor of Music \& Elcn' (elocution?) and his wife Mary (no occupation given) living in Rackham Street, London, a street which no longer exists. Their children are listed as: Julia, Dublin-born, aged 23, 'Teacher of Music \& Elcn (Music)'; the occupation of Harriett, aged 22 and Mary, aged 19, both Dublin-born, is given as 'Berlin Wool Worker (Fancy)'; Hoxton-born William, aged 12 (who might have died in 1883), and Islington-born Helen, aged 8 were 'scholars'. There is no mention of Patrick - had he left home? Married? We do not know. The remaining Allen family do not appear at this address in the 1891 Census.

William Gustavus Allen died in the 'Paddington district' of London, 'aged 62', in 1888. 
1. A very recent book on the theatre is of great relevance: Hazel Waters, Racism on the Victorian Stage: Representation of Slavery and the Black Character, Cambridge University Press 2007. See also Jan Marsh (ed), Black Victorians: Black People in British Art 1800- 1900, Aldershot: Lund Humphries 2006.

2. The early history of Allen is taken from: R.J.M. Blackett, 'William G. Allen: the forgotten professor', Civil War History 26/1 1980, pp.39-52; 'William G. Allen', www.genealogyforum.rootsweb.com; Benjamin Quarles, 'Ministers Without Portfolio', Journal of Negro History 39/1 January 1954, pp.27-42; Sarah Elbert (ed), American Prejudice Against Colour, Northeastern University Press, 2002.

3. Gerrit Smith was in correspondence with British abolitionists such as Joseph Sturge and William Clarkson.

4. On Oneida see Milton C. Sernett, Abolition's Axe, Syracuse University Press 1986.

5. Email from Saray Ebert, 14/1/2004

6. Wheatley, Banneker and Horton, 1849. There are no copies of this available in the UK.

7. Kossuth was well received in the USA, even given a Congressional Banquet. That he did not attack slavery, though he had been instrumental in ending serfdom in Hungary, provoked many abolitionists, including William Lloyd Garrison, to attack him. Allen's letter on Kossuth was published in the Liberator of 9 January 1852. It is reprinted in Carter G. Woodson (ed), The Mind of the Negro as Reflected in Letters Written During the Crisis 1800-1860, (1926), New York: Negro Universities Press 1969, pp.288-290.

8. Allen wrote a total of five articles for Douglass' Paper, which was the 1851 amalgamation of Douglass' previous paper, the North Star, and Gerrit Smith's Liberty Party Paper. The Star had been started with funds raised in Britain, which were partly used to purchase a printing press. Douglass' freedom had been purchased with $£ 700$ raised in Britain in 1846.

9. Remarks on Uncle Tom's Cabin by Wm G. Allen, Frederick Douglass' Paper 20/5/1852 http/ jefferson.village.virginia.edu:1852/utc/responses.

10. Joseph Sturge, a Birmingham Quaker corn merchant had been an active, and radical abolitionist since1826; he was a key figure in the Central Negro Emancipation Committee. Also a peace campaigner, a Chartist and involved in the Compete Suffrage Movement, Sturge was instrumental in founding the British and Foreign Anti-Slavery Society and in organising the Society's Antislavery conventions of 1840 and 1843 . Sturge visited Jamaica to gather evidence on apprenticeship (published as the West Indies in 1837). There he bought the freedom of James Williams, took him to England, published his life story (A Narrative of Events, since the first of August 1834, by James Williams, an apprenticed labourer in Jamaica, London 1837), and used it to press for the abolition of apprenticeship. Sturge also visited the USA and published his account as A Visit to the United States in 1841, Boston 1842. Had he met Gerrit Smith on that visit? He was a friend and working colleague of Thomas Clarkson, whose father had founded the Peace Society which Sturge had joined. See eg. Christine Bolt, The Anti-Slavery Movement and Reconstruction: a study of AngloAmerican co-operation 1833/1877, OUP 1969 and Ellen Gibson Wilson, Thomas Clarkson: a biography, London: Macmillan1989.

11. This excerpt from the introductory letter is printed in William G. Allen, The American Prejudice Against Color. An authentic narrative, showing how easily the nation got into an uproar, London, Edinburgh \& Dublin, 1853

12. Allen and his wife called on Sturge in Birmingham on their way to London from Liverpool where their ship had docked. (The Liberator 22/7/1853)

13. Syracuse University Archives, Gerrit Smith Collection, box 35L: Joseph Sturge to Gerrit Smith $9 / 8 / 1854$

14. In Scotland, the proposal by the Glasgow Emancipation Society to collect a penny from every reader resulted in $£ 1,930$ being sent to the USA. (Bolt, op cit, p.13)

15. Samuel Ringgold Ward, in his Autobiography of a Fugitive Negro (London: John Snow, 1855) mentions the 'unprecedented influence of Uncle Tom's Cabin', and the many aristocrats attending 
anti-slavery gatherings. This did not at all mean that Britain was prejudice-free: see, for example, Douglas A Lorimer, Colour Class and the Victorians, Leicester University Press, 1978.

16. Thompson was a powerful orator, addressing anti-slavery meetings around the country. He had visited the US in 1834-5 in order to collect information for use in the British campaigns. See, eg. Bolt, op cit.

17. This letter is reprinted in Carter G. Woodson (1926), op cit. , pp.284-287.

18. Syracuse University: Gerrit Smith Papers, Allen to Smith, 24 January 1854; the address is 14 Union Road. Allen asks Smith to reply to him care of the Anti-Slavery Office at 27 New Broad Street, London.

19. Their address had been 26 Swinton Street, off Gray's Inn Road.

20. Blackett (1980), p.48.

21. Lady Byron, the poet's estranged wife, had attended the 1840 London World Anti-Slavery Congress, where she had met the anti-slavery campaigners William Lloyd Garrison and Charles Lenox Remond from the USA; she was a subscriber to Douglass' North Star. (McFeely, op cit, p.153) She was had 'sponsored two runaway slaves' (the Crafts) and had funded a reformatory school in Bristol run by Mary Carpenter, who had also supported the anti-slavery movement, but 'felt strongly that [such] enthusiasm should not muffle social injustice at home'. (Susan Normington, Byron and his Children, Stroud: Allen Sutton 1995, p.182; Jo Manton, Mary Carpenter, London: Heinemann 1976, pp.76, 124).

22. American National Biography, pp.346-7.

23. Ripley (op cit, p.358) states that he had obtained an MA degree, but does not give the university or the source for this information.

24. Rhodes House Library: Mss Br. Emp. S.18 c27 Anti-Slavery Papers, Chamerovzow, folio 39, Allen to Chamerovzow 11/7/1854.

25. Some details of this support for the Confederates is in my After Abolition, London: IB Tauris, 2007 and also in an earlier but somewhat fuller account, 'Perfidious Albion: Britain, the USA and slavery in the 1840 os and 1860s', Contributions to Black Studies, 13/14 1995/6 (published 1999)

26. The reference is to James McCune Smith, who attended the University of Glasgow in Scotland, gaining his bachelor's degree in 1835, a master's degree in 1836, and his medical degree in 1837.

27. Leeds Intelligencer, 3 \& 10/12.1853. My thanks to Suzanne Grahame for sending me copies of this.

28. Anti-Slavery Reporter, January 1954; Anti-Slavery Watchman, \#3, January 1854, p.83; there is a brief review of American Prejudice Against Colour on p.79.

29. Anti-Slavery Advocate June and August 1854; Blackett (1980) p.49.

30. Anti-Slavery Reporter, June 1854. The Crafts, who had also sought refuge in Britain, and William Wells Brown were also at the AGM.

31. 5 Wakefield Street, Regent's Square, off Gray's Inn Road.

32. Rhodes House Library: Mss Br. Emp. S.18 c27 Anti-Slavery Papers, Chamerovzow, folio 39, Allen to Chamerovzow 4/1/1855.

33. Leeds Intelligencer, 10/12/1853.

34. Howard Temperley, British Antislavery $1833-1870$, London: Longman, 1972, p.239. This is an excellent source on anti-slavery and the devastating sectarianism within the movement.

35. C. Peter Ripley (ed) Black Abolitionist Papers, Chapel Hill: University of North Carolina Press 1985 , Vol.1, p.332.

36. The Advocate was also sold in England and Scotland. On Webb, see Douglas C. Riach, 'Richard Davis Webb and Antislavery in Ireland', in L. Perry \& M. Fellman (eds), Antislavery Reconsidered, Baton Rouge: Louisiana State University Press, 1979.

37. Webb and Douglass did not get on: see William S. McFeely, Frederick Douglass, New York: W.W. Norton \& Co, 1991, pp.120-123.

38. Gerrit Smith Papers, Allen to Smith, from Cork, Ireland, 23 February 1858. The only address I have for the Allens is 1, Longwood Avenue, Portobello, Dublin.

39. This refers to what is usually called the' Indian Mutiny', that is the uprising of some in India against 
British rule. See, eg

40. Ibid, Allen to Smith from Leamington, England, 14 May 1859. Unfortunately the Leamington papers held at the British Library are so disintegrated that they cannot be read.

41. Ibid.

42. We do not know if this contradicts Sturge's statement quoted earlier that he had met with Allen; perhaps this was not in Sturge's home in Birmingham.

43. Anti-Slavery Reporter July 1863 p.154.

44. My thanks to Carolyn Abel of the Northamptonshire Black History Project. The London Emancipation Society was formed in 1859, as a result of visits by a number of abolitionists from the USA, which had reignited anti-slavery interests. Sadly there is no biography of the remarkable Harper Twelvetrees, who organised lectures, concerts and religious services in the hall he built next to his factory, and supported literary and mechanics' institutes providing education to his workers and other East End residents.

45. Harper Twelvetrees (ed) the Story of the Life of John Anderson, a fugitive slave, London W'm Tweedie 1863. The proceeds from the sale of this book were given to Anderson.

46. Rhodes House Library: Mss Br Emp S.19, Anti-Slavery Papers: letter to Miss Edwards, in the Alexander Sterry Papers.

47. A letter of enquiry to Cassell drew no response.

48. Rhodes House Library: Mss Br. Emp. S.18 c37 Anti-Slavery Papers, f.118. Testimonial for Mrs William G. Allen.

49. My thanks to Caroline Brassey for a copy of this report. On the Society, see Ronald Rainger, 'Race, politics and science: the Anthropological Society in the 1860s', Victorian Studies, 22/1, Autumn 1978, pp.51-70.

50. See, eg Marika Sherwood, 'Race, empire and education: teaching racism', Race \& Class, 42/3, 2001, pp.1-28.

51. ASS Papers, op cit, C. 124 , Chesson files, f.42, Allen to Chesson $8 / 4 / 1878$; their new address was 57 Treverton Street, Ladbroke Grove Road, Notting Hill. See also R. Blackett, 'William G. Allen', Civil War History, \#26, March 1980, pp.39-52.

52. Chatham and Rochester Observer, 16 July 1887. My thanks to Sandra Fowler, who found this and the other Strood references while going through this newspaper searching for references to Black peoples.

53. Chatham and Rochester Observer, 13 August 1887. The group had also given a concert at the Borstal Institute, where 'Allen gave, as usual, a lecture on the negro and his habits'. Chatham and Rochester Observe, 23 July 1887.

54. We do not where they stayed in their travels. Faversham News and East Kent Journal, 10 \& 19 September 1887. I have not been able to locate any further information on this band. Beth Howse, the Special Collections Librarian at Fisk University could not find any mention of William Allen in the jubilee Singers materials held there. (Email 23 Feb., 2004.)

55. Douglas Lorimer, Colour Class and the Victorians, Leicester University Press 1978, p. 203.

56. They clearly moved a number of times. In 1874, they lived in Islington; in 1978 in a boarding house in Notting Hill, a west London suburb. It is from here that Allen's last preserved letter was written

57. My thanks to Guy Grannum of The National Archives for the dates of 'William G.' and his son's deaths. (Email 27 Feb. 2007) 


\section{Extended Review}

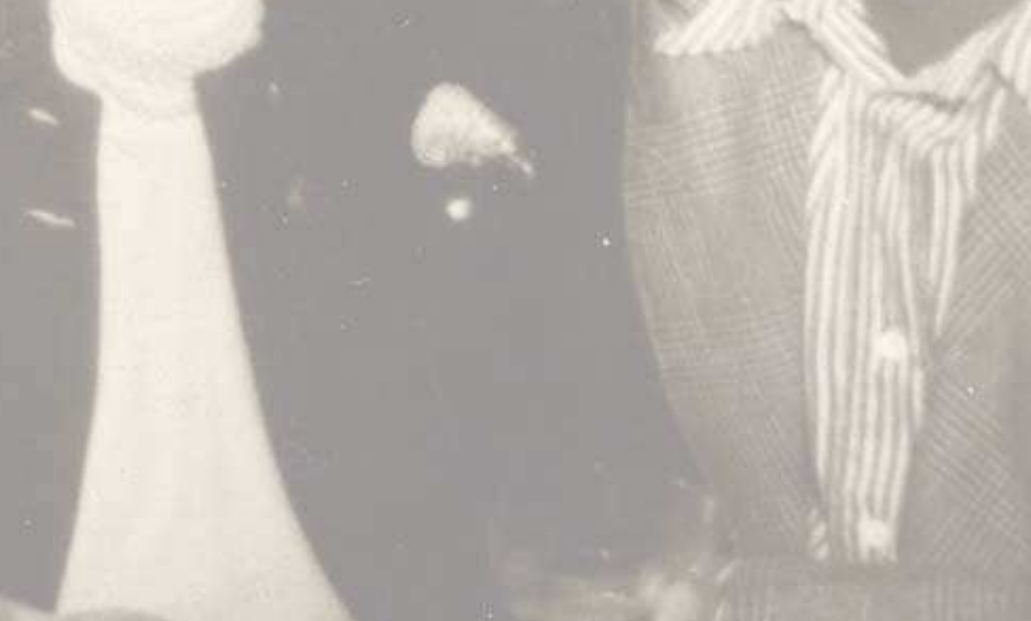


THE TRANSATLANTIC INDIAN, $1776-1930$

\section{Kate Flint}

Princeton University Press, Princeton and Oxford, 2009, pp.376

ISBN 978 o $691131207 \cdot £ 28.95$ (hardback)

Review By Hum, University of Manchester

This study examines the figure of the Native American, considering the image of the 'Indian' in the British cultural imagination and unpicking the ways that this image informed definitions and ideological expressions of British national identity. The study utilises a wide range of arguments, archival research and textual engagements to illustrate how the Native American was used as a symbol in Britain, reflecting both its identity and relationship with America. This was done for a number of political and romantic reasons and marks a transnational movement of cultural myth, image and folklore. Most importantly this work shows how the Native Americans themselves were part of this movement, as material beings rather than simply as symbols.

The study begins by setting out how the image of the Indian became integral to the new nation of the US during the 19th century; informing its expansion, internal policies, national identity and reflections on history. In turn this image is also central to the British conceptualisations of the American continent. The book analyses the emerging dominant trope that Indians belonged to the past, or to an atavistic world that needed to be abolished. The 'Indian' was understood as an 'a-historical other' that the narratives of modernity could be inscribed against. Flint's introduction frames Britain in terms of its empire, emphasising its role as a global imperial power. The relationship between Britain and the US can be seen as contentious: the former colony's increasing imperial drive meant that it was needed as an ally as it was increasing in power, but it also could not be trusted as an honest rival. In this sense the author implicates empire, and in particular Britain, in the negative treatment of the Native Americans whilst also showing that sympathy for their cause could be utilised in the service of imperial identifications.

The author then explores how the repeated image of the dying Indian, found in both textual and visual representations, made the Indian into a figure of pathos, a symbol of what was noble yet destined for extinction. In the US this development of a symbolic figure suggested that the extinction of the Indians was unavoidable, the impact of the introduction of disease from Europe being sidelined and American expansion is supported unequivocally as it is presented as opportunistic rather than destructive. Flint goes on to show how the image of the 'good' Indian and that of the 'bad' Indian became established in Britain, being utilised depending on how they could best serve British interests rather than to engage with Indians as material beings with their own histories and struggles.

The 'bad' Indian was interpreted as wild and savage and as such deserving of his/her fate whereas the image of the 'good' Indian was one who had a common cause with the British, an image that was utilised to argue for the halting of the expansion of America.

The impact of George Catlin is then discussed. He was an American who visited London in the $1840 \mathrm{~s}$ and hosted groups of Ojibwa and lowa as part of his touring exhibition. Through this case study Flint shows how Indians were engaging in the production of their own representation and argues that the Indians wanted the British to understand how Britain was implicated in the causes of Indian poverty that had led them take part in the exhibitions through the need to raise money. She explores how shocked the Indians were by many aspects of British life, especially in relation to the slums and the treatment prevalent in workhouses. This critique demonstrates how the touring Indians were actively engaging with British modernity without compromising their commitment to the validity of their own ways of life. Flint also looks at the way some British women overtly sexualised the Indian men in the exhibitions. By examining public press reports, Flint locates the disapproval levied at these women, both for deigning to have affairs with people they viewed as inferior and also for expressing sexual 
desires. The public disgust attributed to this behaviour, Flint argues, links an implicit racial prejudice to a more explicit expression of domestic sexual politics.

Until the mid century the view of British women writers was either mourning the demise of the Indian or protesting against their treatment. Flint argues that the Indian was an object for compassion, but also an avenue through which disempowerment as women could be articulated. After this moment the representations shifted from 'politically evasive categories of compassion and nostalgia' (p. 111) to anger; rather than focusing attention on compassion for the Indian, it was instead anger for the White man. Flint believes that the portrayal of the persecution of Native Americans by women was often more radical and angry than that found in the work of male authors, as the women were also attacking the masculinity that was represented by the colonising forces. In this we see an enactment of the feminist project of viewing oppressions intersecting, as women writers viewed imperialism in terms of masculinities. This discussion is continued through analysing Longfellow's poem Hiawatha, which deals with the ideal of noble masculinity. Reception of this poem is analysed to explain how Native Americans were understood and engaged with, in relation to masculinity and 19th century American identity.

Flint then focuses on popular writing in Britain and examines how stereotypes of Indians were circulated and modified through domestic concerns. The discussion of Charles Dickens examines how his depictions of Indians reflected his disenchantment with American society; by using the Indian to point to the failings of US society at large, the Indian also became a mechanism by which Britain and the US were made distinct as national projects. Adventure writing by Mayne Reid are also analysed, as the polarised characteristics of Indians - the 'good' and the 'bad' Indian - were exemplified through his representations of characters who were either loyal and courteous allies or violent threats. Flint also draws attention to the ambiguities in Reid's writing that reinforced racial stereotypes and discourses of manifest destiny, but also questioned ideologies of American life.

The following chapter begins with an outline of the popularity of travel fiction and the common move made to collapse racial differences into a common humanity. In such writing, native cultures could only be understood through relativity rather than in their own right. For example, when comment was made on gender in relation to native Americans this was done through a comparison with British or Anglo-American culture. Elizabeth Gaskell's novella Lois the Witch is given attention as instead of relating the Native woman to the English woman, Gaskell stresses the overlaps between their experiences of oppression. Flint's reading identifies ways in which this novella marks a shift in how gender was represented within literary texts to expose the racism of imperialist thought.

Quaker William Howitt's views are then discussed. Howitt levelled attacks at the results of missionary intervention pointing out the links between humanitarianism and colonisation. Flint's discussion considers British missionaries in Canada as well as First Nations converts who toured Britain as preachers, emphasising that the traffic of missionaries moved in both directions. The discussion considers how the missionary approach dealt with the changing world and encounters with difference, as well as the changing face of difference in a larger national context.

The next chapter focuses on Buffalo Bill (Bill Cody)'s Wild West Show in the18gos and takes the discussion to the turn of the century. The show was another American export to Britain and by studying it the author examines the way America was viewed within Britain - as a model of progress and modernity but also as an embodiment of relaxed class structures, mass culture and economic rivalry. There is very little documentation of the Indians' responses to Britain, and although Flint does not discuss this at length, it is interesting to note that in the 1940 Catlin documented a lot of what the Indians did and felt in his exhibitions, whereas in the 1890 Cody did not. This alludes to an increased commodification, identified here through the decrease of interest demonstrated by the 
tour organiser in the Indians, coupled with a heightened awareness of their commercial appeal. For Cody it would seem that they were simply there to be part of the show, revealing an imaginary not a material world, which in fact worked to conceal the realities of native life, such as the move of natives onto reservations.

The discussion is then broadened to address how a comparative understanding of frontiers and subjects was negotiated in relation to America's treatment of Natives; in particular in relation to the increased American influence in Britain - seen to be a form of invasion. Anxiety over this frontier was repeated in relation to the colonial British Indian frontier - a site of struggle in regard to the possible Russian invasion and the rising of Pathan tribes. As well as this, confusion over the term 'Indian' was often produced and used to textual effect in literature. This confusion was a common occurrence in material terms also, with many British people being shocked by the Indians in Catlin's exhibition, as they were expecting to see South Asian colonial subjects. This comparative framework was not always evoked through confusion, though, as at times the Native American was used as the symbol against which all experiences of indigenous peoples were measured. Aboriginal people were expected to be like Native Americans and the 'dying' Indian device was easily applied through poetry in response to massacres of aboriginals.

Flint's conclusion analyses contemporary writings by native peoples, in particular James Welch and Leslie Marmon Silko. These aim to re-appropriate 19th century transatlantic history; the very fact of re-appropriation suggesting that existing historical representations are appropriative. At the 'cusp' of the 19th century, when it became clear that Britain had more to gain from treating the US as an ally rather than rival, the need to assert difference in terms of nationality diminished. This meant that the difference between US and British attitudes towards Native Americans diminished also. These writings use the transatlantic frame to emphasise the dislocation felt by American Indians when engaging with European modernity and also to highlight how the internal colonial relations of the US must be considered within their global frame.

This is a very informed volume that uses an impressive range of literary texts in order to chart a history of representation and interaction. The crucial intervention of Flint's project is in how it implicates Britain in narratives and discourses regarding Native Americans, in a move that demonstrates the long and intimate links that become forged between an empire and its colony. The overarching themes of her discussion are: how national narratives form subjects, how Indians were considered to be a-historical and how they were manipulated for the cause of other narratives, largely because they were not considered to have a stake in a nation's development and so were not defined by a nation. The study also draws attention to the transnational mobility of Native Americans, showing that they were not passive in relation to what was enacted upon them, instead they were active agents in seeking reparations for the theft of their land. This material engagement with Indians highlights that, although they were used as symbols, they were actively resisting this reduction through transnational movement. 


\section{Book Reviews}

\section{Louis Bailey}

Bethan Harries

Saima Latif

Humaira Saeed 


\section{Reviews}

\section{ARTS, LITERATURE AND SPORT}

\section{NIGGER FOR LIFE}

\section{Neal E. Hall}

Publisher: Self published

Year: 2009

Pagination: pp. 265

ISBN: 0972973044

Price: $£ 60.00$

Nigger for Life is a collection of poems by Neal E. Hall. The collection begins with the lines of a poem that state 'to white America I am a nigger for life'. This simple introduction contextualises the title of the book and outlines the volume's focus on racism in the US. Its introduction continues to set out, through recounting Hall's own experiences, how prevalent he believes White privilege, and its associated racisms, are in the US.

Hall outlines how he believes he was 'duped' by the dominant stories of White America such as those of Lincoln freeing the slaves, and those stories that intimated hard work would allow social and economic advancement for Hall and other African Americans towards achieving the 'American Dream'. The injustice he experienced after graduating made him re-evaluate these beliefs as he realised that opportunity was not actually granted equally, regardless of the amount of work he had put in. His poem 'Outside Inside of Outside' demonstrates Hall's own sense of false consciousness as he explores the role of education outlining his beliefs that being taught in the language of the White man will not free the Black man. In later poems he goes on to critique education and its ability to keep Black people misinformed.

The writings contained in this collection span two decades and engage with a variety of themes that focus on the fight against racism. This is drawn together with a call to White people to recognise their privilege and understand that such privilege is part of the machinery of racism - that even if they do not engage in racist behaviour directly, as a whole they benefit from the racism that is enacted. Hall asserts that there are 'white advantages to be secured/and maintained in creating niggers/to keep them niggers' (p.6). In his poems, Hall emphasises the hypocrisy of America in claiming to be changing its attitude towards race, pointing to the continued existence of both racism of individuals and the institutionalised racism that is perpetuated through the State. He points specifically to events such as Martin Luther King's birthday as times when White America 'absolve[s] / itself of the previous 354 days of continuous / racial oppression, injustice and exploitation (p.8).

Hall stresses the ability of poems to inspire Black people to not lose their will and to understand their history in order to achieve liberation. His poems also address internalised racism (Black people do not turing racism on themselves), and consider the role of economics in racial exploitation through racial discrimination, oppression and capitalist exploitation, highlighting the inhuman economic gains of White people and leaders.

In these poems, assimilation and the War on Terror come under scrutiny along with the American criminal justice system. Hall also examines the role of the divergent African American leaders Martin Luther King Jnr. and Malcolm X, with Hall rejecting the former's campaigning as providing a too palatable an anti-racism strategy. Hall, instead brings to the fore his own preference for a resurgence of Black activism in line with the more radical approach of the Malcolm X.

The span of time that Hall's poems address show his changing views regarding racism and his shift towards and expectation and need for a more radical politics in the face of an ongoing and multi-faceted oppression that he terms 'America's continued state of slavery'. This collection provides a fascinating look at one man's changing perspective and his belief that his poems represent the experience of many and the implications for a whole society's future. 


\section{CRIMINAL JUSTICE AND RACIAL VIOLENCE}

\section{RACE, ETHNICITY, CRIME, AND JUSTICE: AN INTERNATIONAL DILEMMA}

\section{Shaun L. Gabbidon}

Publisher: Sage Publications, London, New Delhi, Singapore, Washington DC and Los Angeles

Year: 2010

Pagination: pp. 241

ISBN: 9781412949880

Price: $£ 21.99$ (paperback)

This book sets out to explore the nature and scope of the race/crime relationship and investigate the initial and long-term effects of colonisation on crime and justice for racial and ethnic minorities. The volume gives a chapter to each of the following countries, which were selected due to the centrality of colonisation or other repressive systems in structuring the society: Great Britain, the US, Canada, Australia and South Africa.

The study aims to analyse the 'dilemma' of the relationship between race, ethnicity, crime and justice across the aforementioned countries to examine the similarities and differences between them. Gabiddon identifies this 'dilemma' as the outcome of early European colonisation which has lead to racial and ethnic minorities being excessively targeted for attention by the justice system. The book provides numerous tables providing fascinating and in-depth analysis of crime and population demographic statistics.

In the opening chapter, Gabiddon outlines his framework in assessing each of the five countries. First he expands on his use of the Colonial Model - the theory he uses to contextualise race and crime - and from the outset he is clear that the links between colonialism and criminology are drastically under-explored and consistently excluded from the criminology canon. The chapter proceeds by discussing in brief external and internal colonialism and their links to racial discrimination, and concludes by outlining the pitfalls of using crime statistics cross-nationally and without the use of contextualising data.

The subsequent chapters on each country follow a similar format; each one providing a overview, a history regarding race and ethnicity in that nation, an overview of its criminal justice system and current demographic information of its citizens. This is followed by a summary, conclusion and references. Each chapter also provides sub-headings of particular relevance to the country in question, allowing the book to explore in more specific detail the research and laws pertaining to that country.

In the chapter concerning Great Britain, Gabbidon reviews migration patterns to examine how crime became part of ethnic minorties' everyday experience. His study culminates in an evaluation of racial and ethnic minorities in the criminal justice system today. In his subsequent examination of the United States, he looks at the different groups who have been considered a 'criminal justice problem' in the country, from Native Americans to African Americans and the shifts in their experiences over time.

Chapter four looks at Canada and outlines the history of early European colonisation of Aboriginal land and the current experiences for those Aboriginal people and those termed as 'visible minorities' (non-Caucasian in race and non-White in colour, which does not include Aboriginal people) in Canada today. In the following chapter looking at Australia, Gabbidon continues his examination of European colonisation which has culminated in an over-representation of Australian Aborigines in the criminal justice system. He also explores the efforts to reduce this.

In Chapter six, Gabbidon focuses on South Africa and discusses the disorder caused by Dutch and British colonisation and the racial divisions caused by the discovery of gold and diamonds. Later in the chapter he also looks at the country in its post-apartheid incarnation to consider its crimerelated challenges.

In his conclusion, Gabiddon brings his findings in all of the featured countries together and outlines both the specificities and the similarities within which ethnic minorities negatively experience their home/host countries' criminal justice systems, and the way in which such experiences may help 
towards generating an international understanding of how ethnic minorities experience crime.

\section{QUEER IN BLACK AND WHITE: INTERRACIALITY, SAME SEX DESIRE, AND CONTEMPORARY AFRICAN AMERICAN CULTURE}

\section{Stefanie K. Dunning}

Publisher: Indiana University Press, Bloomington and Indianapolis

Year: 2009

Pagination: pp. 136

ISBN: 9780253221094

Price: 114.99

This study examines African American cultural productions in fiction, film and music that feature interracial desire in the context of same-sex desire to consider the implications of this intersection on expressions of Blackness.

The introduction dissects some of the ideas examining homophobia as part of Black communities and racism as part of White gay communities. By situating the discussion between discourses that locate queer as antithetical to Black nationalism or define it as White, the book aims to address both of these claims as faulty through looking at texts that engage with both same-sex and interracial desire.

The film Jungle Fever is cited through a quotation that equates gay Black men with criminality and drug addiction as well as connecting them to Whiteness - thus suggesting that being sexually and socially available to Black women is that which makes Black men part of the Black nation. Here 'the equation of interracial desire and gay identity connects queer identity to that which is outside' (p.4), and Dunning uses this to set up her argument for reading texts in more complex ways that locate both the interracial and the queer as part of Black nationalism. She also examines the film Tongues Untied by Marlon Riggs to highlight that, whilst the film idealises relationships between gay Black men, inscribing Black with queer, in reality Riggs's was engaged in a long-term relationship with a White man. An intertextual reading allows us to locate the interracial relationship of Riggs's life in the image of Black nationalist gay relationships in the film.

Chapter one looks at Me'Shell NdegéOcello's album Plantation Lullabies which deals with negotiated nationalisms. Again Dunning argues for the inscription of queerness within the Black nationalism expressed within the music, through identifying the use of ambiguously gendered terms. Images of NdegéOcello that accompany the CD elucidate this ambiguity of both gender and sexuality within her music and NdegéOcello openly self-ascribes as bisexual.

The following chapter looks at Eldridge Cleaver's essay 'Notes on a Native Son' and considers its attack on author James Baldwin. In the essay, Cleaver argues that to be both homosexual and Black is to have a hatred for Blackness, to feminise oneself - and that this is doubly true if homosexual relations are with a White man. Later in the chapter, Dunning focuses on Baldwin's novel Another Country and examines Black Nationalism with a focus on the novel's character Rufus, as well as questioning submissiveness and race in terms of his sexual relations.

In Chapter three, she evaluates the novel Loving Her by Ann Shockley - the first novel to focus on a Black lesbian protagonist. The novel is evaluated as a rejection of the sexist logic of Black nationalism and contests the idea of Blackness as male and heterosexual. The novel also portrays interracial love as the protagonist's salvation and this chapter analyses the critiques of this plot that view it as problematic in a queer Black context.

Finally, Dunning looks at Cheryl Dunye's film The Watermelon Woman as a means to analysing the history and body of the Black lesbian. The relationship of the main character - a Black woman - with a White woman provides a narrative for exploring the different experiences between the women due to their races; allowing the film to comment on Blackness through their relationship.

Overall the book allows the reader to consider that in allowing Blackness and Whiteness to interact within them, each of these texts elucidate how their featured interracial relationships allow for, and provide, the opportunity for them to examine Blackness. Dunning argues that if the interracial 
relationship makes Blackness visible, then assertions from certain Black Nationalist canons that imply having intimate relations with White people is deracinating cannot be correct. In conclusion, she argues for a reading of these texts that firmly situates them in the African American tradition, where Blackness is asserted not undermined within the context of same-sex desire.

\title{
POLICING AND THE LEGACY OF LAWRENCE
}

\author{
Nathan Hall, John Grieve and Stephen P. Savage (eds), foreword by Doreen Lawrence OBE \\ Publisher: Willan Publishing, Cullompton and Portland \\ Year: 2009 \\ Pagination: pp.296 \\ ISBN: 9781843925057 \\ Price: $₫ 22.00$ (paperback)
}

This volume marks the tenth anniversary of the Stephen Lawrence Inquiry and explores the impact of the inquiry on policing policy. The book closely and carefully considers how far the recommendations of the enquiry have been incorporated into the various areas of service delivery. Contributions to the volume come from a range of perspectives, that include contributions from key policing figures and chapters that are based on personal reflection. The book includes a foreword by Stephen's mother Doreen Lawrence.

In their introduction, the editors introduce six dimensions of the Lawrence legacy: cultural, governance, political, legal, intelligence and international. They also discuss the role of the Lawrence Inquiry in police reform, outlining themes that emerge within the book and pointing to other studies in the field of race and policing.

The volume is split into three sections:

Part One is entitled 'Lawrence in Context' and has three chapters. Initially in this section, the authors look at the Stephen Lawrence murder investigation and the subsequent miscarriage of justice and failures of the police system. In addition, the chapter also questions why the Lawrence case became a watershed in British policing. The following chapter documents a conversation between one of the book's editors John Grieve and Ben Bowling, Professor of Criminology snd Criminal Justice, who has undertaken research on violent racism and hate crime and also acted as a witness to the Stephen Lawrence Inquiry. Finally the first section looks at police engagement with communities post the Inquiry by assessing the key achievements, weaknesses, and level of independence of the Independent Advisory Group.

Part Two has four individual chapters and is called 'Lawrence and Operational Policing'. The first chapter in this section, Chapter four, examines the Inquiry's recommendations, the Home Office recommendations, and the development and implementation of both the Anti-Racist policing strategy and the Diversity Strategy. It also examines the importance of 'street level' officers in providing leadership for following initiatives. Next, the editors provide a personal reflection by P.C. Bill Griffiths who formed part of the investigatory team into the murder of Damilola Taylor in 2001. This personal account charts the changes within the Metropolitan Police Service since the charges made by the Lawrence Inquiry. Chapter six considers the relationship between concepts of intelligence that were developed independently of the Lawrence Inquiry and the alternative forms of intelligence that emerged as a response to the Inquiry. Chapter seven is comprised of further personal reflection, this time by Jonathan Crego on the impact of public enquiries on training. Crego co-created the Strategic Management of Critical Incidents training regime that was informed by the lessons of the Lawrence Inquiry. The final chapter eight, by the Director of Kingston Racial Equality Council looks at the importance of independent advice and its involvement with the Lawrence Inquiry.

Part Three, 'Lawrence - Widening the Agenda', looks at the implications of the Inquiry and related initiatives outside of the criminal justice arena. The opening essay of this section, chapter 9, discusses the impact of the Lawrence Inquiry on developing community and race relations training; it goes on to question whether training is the appropriate way to achieve the outcomes of the Inquiry, asking whether education would be more effective. The subsequent chapter ten, looks closely at an empirical research study that examines the differences in perception between the police officer and 
the victim of the same racist incident, suggesting that a better understanding of this 'perception gap' (p.215) could contribute to developing an improved policing service. The final chapter of the book provides the concluding overview of the progress of the educational recommendations of the Inquiry. In particular, it questions the lack of reference to, and consideration of educational practitioners in the final recommendations, such as trainee teachers, teachers or school governors.

\section{BLOOD AND CULTURE: YOUTH, RIGHT-WING EXTREMISM, AND NATIONAL BELONGING IN CONTEMPORARY GERMANY}

\section{Cynthia Miller-Idriss}

Publisher: Duke University Press, Durham and London

Year: 2009

Pagination: pp. 295

ISBN: 9780822345442

Price: $£ 17.99$ (paperback)

This study is based on an ethnography carried out at vocational schools in Berlin between 1999 and 2004. Miller-Idriss interviewed 119 young people, 31 teachers and engaged in numerous classroom observations to question how national identity is experienced and constructed differently across generations, and how the young people negotiated their different approaches between citizenship and national pride within the classroom. This discussion also considers class differences between the mostly working-class students and middle-class college-educated teachers.

Miller-Idriss looks at how the specific history of the Holocaust and World War Two make understanding and developing a national identity particularly challenging for Germans, especially with regard to different generations. The repeated explanation by teachers regarding why it is important to reject the fascistic articulations of national affiliation shown by the generation before them can often lead to a backlash against such views by their students; with these student actively seeking an opportunity to take pride in being German. The author also reflects that this is engaged in with the concept of being German very much understood in cultural rather than ethnic terms.

The introduction looks at the current cultural landscape of the German capital, Berlin, considering the changes brought about through migration and globalisation, as well as providing an outline of the German school system. It also discusses the notion of belonging and the concepts of imagined national communities that are articulated through state practices such as public education, whilst highlighting that such practices also require adherence by individuals in order to be cohesive.

Comprised of six chapters, the book initially looks to contextualise this study within theories of nations and nationalisms and outlines the assumptions of engagements with German nationalisms that see them as constructed through blood rather than culture. Next, it further locates the study by looking at citizenship, naturalisation, belonging and identity throughout history, looking closely at the years leading up to and proceeding World War Two. Following this, the author turns to the ethnographical research she undertook and focusing on the interviews that debated the expression of German pride, also looking at the student responses to public discourses that associate national pride with right-wing activities.

In chapter four, Miller-Idriss investigates what ideologically constitutes the far-right in Germany and how these ideas are engaged with by those in her study. She considers this from a range of standpoints - from in-class observations, teacher training workshops, through to curriculum and interventions. She also looks at the life stories of people in the far-right as well as those who were previously associated with the far-right. The next chapter looks at schools more closely and its content is based on an analysis of the classroom observations to see how citizenship and identity are dealt with by teachers in their roles as public sector workers. Miller-ldriss notes that this approach is very purposeful and resistant to right wing ideas and so also uses the chapter to outline the students' reactions to this and elucidate how their own opinions develop in response to this. Chapter six provides an extension of the generational change evident in the distance between the opinions of teachers and students and identifies the younger generations' culture-based nationalism, which challenges dominant ideas that German-ness is defined through blood. 
The final chapter, seven, provides a conclusion of the study and revisits the notion of national construction in order to consider how the younger generation is redefining the nation and the ways in which these do and do not create democratic and tolerant citizens. Miller-Idriss also uses this final section to question whether a final conclusion can be made as to whether the appeal of the right wing is generated through a generational backlash or as a youth movement that expressing its distinction from the older generation.

Readers of the book also benefit from the inclusion of two appendixes: one providing an overview of the schools studied in Berlin that includes contextual information on staff and students as well as details of the student demographic; and the other the methodology which outlines the processes of questionnaire design and data collection. The appendixes provide an important further tool of contextualisation for the wider text.

\section{RECONSTRUCTING LAW AND JUSTICE IN A POSTCOLONY Nonso Okafo}

Publisher: Interdisciplinary Research Series in Ethnic, Gender and Class Relations Series, Ashgate Publishing, Farnham and Burlington

Year: 2009

Pagination: pp.249

ISBN: 9780754647843

Price: $£ 60.00$

This study of comparative law examines the experience of recreating law and justice in societies that have just emerged from colonial rule or internal dominations. Through analysing information gained from twelve post-colonies: Afghanistan, Australia, Brazil, Canada, India, Iraq, Japan, Kenya, Nigeria, Saudi Arabia, South Africa and the US, Okafo argues that any post colonial reconstruction needs to consider the traditions and customs of a society as well as official laws that have been imposed by the colonial powers. The chapters of the book investigate elements of indigenous-based and foreignbased law systems applicable in a country, and include an in-depth look at the Nigerian experience. The book has four parts.

Part one explores the critical importance of customary law in contemporary times and argues that all laws are rooted in custom. He utilises the term 'grounded' to describe a law's connection to the culture from which it is developed. Okafdo also aims to avoid any assumptions that grounded law is inferior to foreign law if it is able to remains effective and efficient; and he subsequently assesses the effectiveness of traditions in rural and industrial societies and defines the differences between these societies in their justice characteristics.

Part two evaluates the relationship between indigenous and foreign laws in each of the twelve countries. This section provides an international comparative perspective on home-grown law versus foreign systems via comparisons of geography, history, and relations of certain elements of law to others; it also presents the key similarities and differences between the countries. By comparing colonies of different countries, Okafo aims to give an insight into the effects of different forms of domination, for example looking at the distinct effects of British modes of 'indirect rule' compared with French methods of 'assimilation' and examining each country's efforts to 'reconcile the indigenous and foreign law' (p.35).

Part three focuses mostly on Nigeria to examine the processes and results of a reconstructed legal system and offers suggestions for successful rebuilding, outlining the challenges of creating an effective legal system within an emerging nation. Okafo also recounts the history of Law in Nigeria, explaining how the English 'Common Law' system was imported to Nigeria and to create the general law - pre-existing laws were presented as backward and not considered to have the requisite authority. The discussion extends to consider how, even after independence, Nigerians are ruled by English law and the book argues for a more pragmatic law to be instigated that incorporates a more direct engagement with African-based life, stating that a '[P]roper law and justice restoration would yield an indigenized postcolonial system in which the age-old indigenous systems are synthesized 
and blended with appropriate elements of the foreign systems' (100).

Part four concludes the book by insisting on the need for a new outlook on law and justice, offering ideas based on a shared responsibility by both governments and citizens. By urging for a sense of common owner-ship so more feel invested in the legal system, countries would also shed one legacy of colonial rule - lack of trust in government and the expectation that laws will be imposed rather than participated in.

The book also has one appendix - the questionnaire used by Okafo to interview people connected to the Nigerian legal systems.

\section{RELUCTANT GANGSTERS: THE CHANGING FACE OF YOUTH CRIME John Pitts}

Publisher: Willan Publishing, Cullompton and Portland

Year: 2008

Pagination: pp.176

ISBN: 9781843923657

Price: $₫ 22.99$ (paperback)

This book is based upon a study using field research undertaken in three London boroughs between 2005 and 2008 which was part of Pitts long term commitment to researching this issue. In these boroughs, including Waltham Forest, Pitt researched the prevalence of youth gangs, and their social impact on the neighbourhood. He also evaluated a gang desistence programme - interviewing its participants and peer mentors, spoke to volunteers working in gang-affected neighbourhoods and the young people and parents from those areas. In total, Pitts talked to over 300 people from areas affected by gangs.

Chapter one introduces the framework for the book and looks at existing research into youth gangs and surveys compiled in the late twentieth century. During the 1980 s and 1990 s there was no evidence of youth gangs, and the gangs that existed were mostly made up of White adults - evidence which challenges the perceptions that gang membership has always been a problem associated with young people of colour. Pitts notes that in starting the research for this book, many respondents expressed a sense that something had changed in the last decade, with the results to preliminary questionnaires and police reports highlighting problems with youth gangs that had developed over the past five to eight years. Significantly, as the number of gun crimes has risen, the age of the perpetrators has dropped. Further to this Pitts points out how, although there has been an overall decrease in crime in Britain, there has been an increase in certain areas with certain groups becoming more criminalised.

In Chapter two, Pitts looks closely at the term 'gang' and the surrounding scholarship, looking at the body of work that has emerged from the US and has become increasingly influential in Europe. Chapter three examines gangs and criminality within Britain through looking at two dominant theses: 1) one that sees youth crime as a problem of governance and external social forces, and 2) which identifies the individuals involved as inherently disruptive. Later in the chapter a possible third option is considered - the 'political economy' of gangland (7).

The author uses chapter four to argue that gangland is the result of gentrification and the connected estrangement of certain groups from political participation into social exclusion. In the following chapter, organised crime, the international drugs trade and street crime are discusses and Pitts argues that such criminality has informed the emergence of gangs. Chapters six and seven look at the role of gangs in the development of young people's world views and the appeal of gangs for young people, with the later involving consideration of the perceived safety and support provided by gangs.

The final two chapters, eight and nine, look into the wider impact of gangs on the areas in which they operate and give consideration to the policy changes that are needed to alleviate this impact - Pitts looks in detail at the government initiative 'Every Child Matters' to see how its principles could be applied to gangland related interventions.

Overall the books provides a variety of accounts of armed youth gangs in his chosen locations 
and reveal the devastating impact that gangs can have on their members, the wider communities, and those charged with safeguarding the all. Essential to Pitts' text is his stress on the link between the private troubles of young people affected by violent youth gangs and the public issues of the estrangement of their neighbourhoods from the socio-economic and political mainstream, providing evidence that gangs exist through a multitude of problems that cannot be understood or dealt with in isolation.

\section{RIOTING IN THE UK AND FRANCE: A COMPARATIVE ANALYSIS}

Edited by David Waddington, Fabien Jobbard and Mike King

Publisher: Willan Publishing, Cullompton and Portland

Year: 2009

Pagination: pp. 276

ISBN: 9781843925040

Price: $£ 45.00$ (hardback)

This book was created following a series of workshops between British and French academics interested in French and British rioting in the late twentieth century and early twenty-first century. It is a collection of essays reflecting this collaborative work engaging with three main strands of interest:

1) an analysis of the British riots of the 1980 (in cities such as Liverpool, London and

Birmingham), 1991/2 (in various cities across the UK), 2001 (Burnley and Oldham) and 2005 (Bradford and Birmingham);

2) an analysis of the French riots in 2005 (beginning in Paris but spreading across France); and

3) the introduction of a collaborative framework which also examines rioting in Germany and the US.

The volume aims to engage with the antecedents and aftermath of riots and emphasises the need for a full sociological analysis of the locations of riots, how they started, and the roles of the state and/or existing race relations.

In Part One, Chapter one contextualises the riots in Britain in 2001 and in France in 2005 and aims to understand the causes of the French riots through an analysis of British riots, as well as looking at recent studies by French scholars. Chapter two examines the disorders in Britain in the 1980s and 1990s, evaluating academic approaches to them, presenting an overview of events and an outline of theories and the subsequent chapter provides a similar analysis and overview of the French riots 1981-2004

The whole of Part Two focuses on the British riots of 2001 and 2005, and contains four chapters - each analysing a different aspect of the riots. Firstly, they look in depth at local history of the riot locations, as well as the mechanisms by which rioters assembled, whether the hierarchical regime of policing is compatible with sensitivity to diversity. They also utilise interviews carried out in Bradford between 2003-5, with convicted rioters, third-party observers and police officers. In the ensuing analysis the authors dissect the assumption that riots are enacted by groups holding a collective identity and opinion - arguing that where rioting groups may look homogenous there is a wide-range of motivations for involvement as well as a mix of attitudes towards police and violence. Finally consideration is given to the government strategy of 'community cohesion' that was developed in the aftermath of the 2001 riots, asking why these riots were such a watershed for policy. The discussion draws on field research on the impact of community cohesion work with young people in Oldham.

Chapter eight examines the uniqueness of the 2005 clash between South Asian and AfricanCaribbean youths in Lozells. The chapter outlines the events of this disorder and the police operation linking this in to a comparison with the 1980s Handsworth / Lozells riots.

Part Three looks in depth at the French riots of $2005-8$, and is comprised of five chapters (ninetwelve). Initially this section investigates the structural variables that were at play in relation to the 2005 riots to question what it was about this time that generated riots, with the first chapter analysing the role of population segregation, employment ethnicity and family size. Subsequent chapters in this section explore the relationship between riots and urban regeneration programmes, considering the often racial dynamic of these programmes; as well as how participation in social life can potentially 
cause rioting and the differences between first and second generation migrants' attitudes towards political involvement. Finally, in chapter twelve, consideration is given as to whether riots can be considered to be a political protest, and the differences in the political beliefs and lifestyles of those who chose to riot and those who chose not to participate.

Chapters thirteen look further at field study of youth gangs involved in the UK riots, as well as some riots in Germany and the US. Analysis in these chapters assess the relationship between delinquency and rioting, and further discuss the role state agencies such as the police and government have in the development of rioting and potentially inflaming rioters, leading to escalations in violence. The book concludes by drawing together the lessons of the contributions and re-engaging in a comparative study of France and the UK. It closes by looking at current preventative policies and how these engage with ideas of multiculturalism and race relations.

\title{
CULTURE, IDENTITY, GENDER AND RELATIONSHIPS
}

\author{
IMPERIAL SUBJECTS: RACE AND IDENTITY IN COLONIAL LATIN AMERICA \\ Edited by Andrew B. Fisher and Matthew D. O’Hara, foreword by Irene Silverblatt, \\ Publisher: Duke University Press, Durham and London \\ Year: 2009 \\ Pagination: pp. 303 \\ ISBN: 978 o 823344209 \\ Price: $£ 14.99$
}

Fisher and O'Hara's collection is based upon the premise that race and ethnicity in colonial Latin America were fluid and that its communities had diverse understanding of themselves as individuals and imperial subjects. The introduction discusses the relevance of identity to the study of the Iberian colonial world, emphasising how identity is formed through interactions between imperial subjects and the colonial institutions.

They argue that Colonial reality was formed by a multitude of interactions among imperial subjects, and this collection aims to unpick 'how Iberian settlers, African slaves, Native Americans, and their multiethnic progeny understood who they were as individuals, as members of various communities, and ultimately as imperial subjects' (p.). The collection insists on the importance of studying identity in relation to the contextual social formations and of studying it historically, and seeks to explore how structures of rule impacted on lived experience and as such, created identities. The eight contributions to this book span the colonial era and beyond, each focusing on a different aspect of the identities embodied by imperial subjects. Jeremy Mumford starts the collection with a discussion of the Perpetuity Controversy in Peru in the sixteenth century - a conflict between the Crown, indigenous lords and Spanish counterparts which led to more complex understandings of their identities and the relational power different subject positions held.

Jane E. Mangan then charts the evolution of colonial racial hierarchies and categories for indigenous and Mestiza women involved in urban trade, detailing how their assertive engagement with this social space challenged gendered and racial assumptions and the terminology used to discuss their existence and experience. David Tavárez also addresses terminology to show how generic terminology failed to adequately represent the complex identities and interactions of subjects.

Cynthia Radding looks at borderland societies to consider the ways in which colonial ideologies can persist in locations at a distance from the imperial centre, and how the flux in populations meant that meanings used to describe inhabitants also coalesced. Mariana Dantas's chapter focuses on Brazil and the use of colonial racial categories in the eighteenth century, examining how Black people - both enslaved and free - carved out their own spaces in colonial society despite racist attitudes.

Dantas specifically examines the ways in which Black people utilised racial categories to articulate themselves as imperial subjects. Ann Twinam continues to explore Black social mobility through discussing processes in late colonial Spanish America whereby Black citizens could secure White identity from the king - identifying the sources of colonial discourse around Whiteness and its impact on how race was understood. 
Sergio Serulnikov's essay is concerned with the united response of Creole patricians and nonWhite plebeians in La Plata to the abolishment of its militias. The imposition of a royal garrison of Spanish troops is identified by Serulnikov as generating a unique alliance between patricians and the town's non-White populace. Maria Elena Diaz analyses how imperial subjects constructed ambiguous identities by looking at royal slaves in Eastern Cuba who were awarded a level of self-governance in exchange for their obedience. Finally, Karen Caplan concludes this volume with her examination of how indigenous communities and state governments of Oaxaca and Yucatán modified and challenged established colonial institutions in the years following Mexican independence. Caplan highlights how, in so doing, postcolonial citizenship and identity was being negotiated.

Overall the collection aims to bring into discussion the creativity and agency with which imperial subjects in Latin America navigated their colonial and postcolonial worlds.

\section{CULINARY FICTIONS: FOOD IN SOUTH ASIAN DIASPORIC CULTURE Anita Mannur}

Publisher: Temple University Press, Philadelphia

Year: 2010

Pagination: pp. 255

ISBN: 9781439900789

Price: $£ 18.99$ (paperback)

This volume focuses on the role of food in describing South Asians in the diaspora in literature, film and Television. Mannur's argument considers how national identity, home, belonging and racialisation are all articulated through the culinary and aims to highlight the politics and symbolism of food.

The introduction analyses various comments that assign the smell of Indian food to Indian bodies in negative and racialised ways so as to 'illustrate the multiple complexities and conflicts enmeshed with culinary rhetoric' (p.5). The chapter also emphasises how food repeatedly becomes the matrix by which the difference of South Asian bodies is discussed. The study aims to focus on the Anglo-American diaspora of South Asia, to also pay attention to the interchange between the US and other diasporic sites, considering how an 'understanding of home, Diaspora, and migration become complexly intertwined with food and belonging within gendered hierarchical structures' (p.10). The introduction also engages in a discussion of food studies as a discipline. Mannur considers food as a discursive space that exists beyond an action of a symbol of group identity and moves into an understanding of food as a register which we can use to theorise gender, sexuality, class and race. The study is split into three sections each comprised of two chapters: 'Nostalgia, Domesticity, and Gender', 'Palatable Multiculturalisms and Class Critique' and 'Theorizing Fusion in America'.

Chapter One analyses the affective role of food in experiences of dislocation. For this discussion Mannur coins the term 'culinary citizenship' which addresses the identities that can be forged and claimed through food. She looks closely at the work of Shani Mootoo, Sara Suleri and Madhur Jaffrey to consider how food is always available as the script through which to talk about displacement and belonging. In ChapterTwo, she addresses the site of home as one that genders and disciplines subjects whilst also allowing for alternative rendering of the space. The chapter ties several texts together (Ismat Chughtai, Romesh Gunesekera, Shani Mootoo, Mira Nair, Deepa Mehta) to emphasise the compulsory heterosexuality embedded in food, family and the home, to then explore how this is underpinned with the possibilities of a queer kinship that can be articulated through food.

In the second section 'Palatable Multiculturalisms and Class Critique', Mannur begins by highlighting the expression of colonial power through investments in the trade of sugar and spices and goes on to consider the notion of 'food pornography' whereby writers engage in a form of self-exoticisation by exaggerating their food in terms of its otherness. She looks closely at Chitra Bannerjee Divakaruni and Bharati Kirchner to discuss how racialisation is expressed through food via multiculturalism Subsequently she addressed the issues of race and labour and looks at the film Mirch Masala to consider the gendered and classed labour inherent in food production. Here Mannur considers how and when the image of food is pitched away from romantic ideas and onto harsh realities of labour that make 'antiporn'. 
In 'Theorizing Fusion in America', the final section of the book, the author looks at writings that engage with the experiences of second generation characters in the US. The discussion begins with Indiana Jones and the Temple of Doom and Jhumpa Lahiri's fiction to consider how food is a way that abjection is expressed - but can also become the medium where a desire to resist abjection can be expressed. Mannur then goes on to frame Harold and Kumar go to White Castle within the unexpected narratives of migration and nostalgia. Finally, she explores the political meanings articulated via a variety of cookbooks highlighting that some act to manage immigrant excess whilst others act to restrict it - illuminating how food can be a disruptive form of culinary difference.

The book culminates by the author reminding us what is at stake in discussions of food, especially within discourse of multiculturalism. Her conclusion emphasises how food is used to make south Asians palatable and consumable and that we need to look for alternate readings and expressions that note the nuances, range and contradictions that emerge from culinary fictions.

\section{AFGHAN WOMEN: IDENTITY AND INVASION}

\section{Elaheh Rostami-Povey}

Publisher: Zed Books, London and New York

Year: 2007

Pagination: pp. 159

ISBN: 9781842778562

Price: $₫ 16.99$

This book argues that women's rights in Afghanistan must be understood within the global perspective of imperial domination and the tensions between Muslim countries and the West. Rostami-Povey discusses how region, ethnicity, conflict and colonial interventions affect approaches to, and treatment of, gender, emphasising that historical context is crucial to any understanding of these. A central concern of the book is to 'counter the often inaccurate and misleading impressions put about by the media and politicians in the West when they talk about Afghanistan and Afghan women in particular' (p.xi). Rostami-Povey argues against popular stereotypes to demonstrate how US intervention in Afghanistan has not lead to any improvement in conditions for women, and to highlight that the challenges facing Afghan women are both global and local.

In Chapter One, Roastami-Povey recasts popular arguments regarding Afghan women to emphasise that any discussion needs to consider the challenges faced by Afghan women within, and by, the West - rather than only apportioning blame to historic and current Afghani culture. She also highlights the resilience of Afghan women, focusing on their struggle for rights to illuminate how these women are agents for change. The discussion takes as its starting point the symbolic role that women have played in Afghan politics, their experiences and their survival strategies at the time of Taliban oppression, US invasion and the current occupation.

In the following chapter, Roastami-Povey considers communal identities and gender relations in more detail by looking at the situation for women under the Taliban and focusing on women's survival strategies. It explores the solidarity of men and women when under Taliban rule, arguing that this coalition between genders enabled women to be mobile and run operations such as secret schools. The co-operation of anti-Taliban men and women meant that expected gendered practices such as Mahram, (whereby women must be chaperoned by male relatives when in public), were performed in order to allow these women to carry out these forbidden activities. In this way, the enactment of an image of male domination was actually an enabling force for women, and as such Rostami-Povey argues that we must be wary of interpreting Mahram as a straightforward expression of male domination as often these actions were more complex.

Chapter Three addresses the impact of reconstruction, questioning whether it is better for women in Afghanistan after the US-led invasion. This chapter argues that the presence of foreign forces weakens nation-state building as Western imports such as Market liberalism create tensions between the state, foreign private companies and warlords. The challenges of being under invasion also include the rise of the opium economy; the insecurity of the nation-state and the resulting conditions force many to leave for Pakistan and Iran. Roastami-Povey considers the impact of these 
contextual shifts on women's experience in particular.

The next chapter focuses on the experiences of Afghan women in the diaspora, exploring the tremendous support given to them by feminist movements in Iran and Pakistan, and comparing these to the limited connections with US and UK movements. This chapter considers the impact of $9 / 11$ and 7/7 on women's consciousness, and through a comparative study of diasporic communities, RostamiPovey uses interviews to discuss the isolation and racism experienced by women in exile. She also examines how Afghan women in Pakistan and Iran started to break free from lives of domination and marginalisation through negotiating their own feelings and attitudes regarding patriarchy and Islam.

The book concludes by charging imperial agendas as posing the ultimate challenges to women in Afghanistan, arguing for a need to reconceptualise women's rights and democracy within the context of imperialism and invasion thus creating a challenge for local feminism and the larger global context.

\section{VISIBLY MUSLIM: FASHION, POLITICS, FAITH}

\section{Emma Tarlo}

Publisher: Berg Publishers, Oxford and New York

Year: 2010

Pagination: pp. 241

ISBN: 9781845204334

Price: $₫ 19.99$ (paperback)

In this book Emma Tarlo begins by noting the increased visibility of faith amongst Muslim women over the past decade and considers why dress is such an important issue for Muslims. She asks why this has become a matter of such media and political interest and aims to explore the diversity of clothing that is worn to express Muslim identities and concerns today. Tarlo questions why this diversity of expression of faith is reduced by the mainstream to be one particular gendered look that is considered repressive. The book aims to contextualise Muslim dress practices in Britain as ones that are undergoing major transformations and reflect 'complex debates about identity, faith, politics, ethics, aesthetics and belonging' (2). It also sets out to focus the discussion on the experiences of those wearing the clothes themselves to identify what the clothes mean to them and what impact their dress has on their engagement with public space.

The introduction incorporates a critique of the dominance of 'the veil' in any discussion of Muslim women, highlighting how many of these discussions are ingrained with binaries of for/against, liberative/oppressive, stating that this book hopes to move beyond this reductive approach. Through pointing to the diverse cultural backgrounds of Muslims in Britain she highlights the many different clothing traditions that have been incorporated into fashion trends, that can be called Muslim and are then worn by Muslims from a mix of different cultural backgrounds themselves. As such, Tarlo argues, there are many nuances of visibly Muslim appearances in Britain today that are subsumed under the generalised term 'the veil'.

Next, Tarlo present three biographies of professional Muslim women - Rezia Wahid, Shazia Mirza and Humera Khan - to emphasise the variety of changing factors that have influenced their clothing practices. Through this the chapter indicates the complexity of their stories and analyses how individual histories and experiences become incorporated into dress styles.

In chapters three and four, Tarlo shifts the focus by engaging with a White British convert to Islam who wears hijab to explore ideas of multiculturalism and agency. This chapter also considers how meanings of the hijab are shaped by conceptual and contextual factors such as the 'war on terror'. The next chapter looks at how young women have experimented with style through incorporating their own personal aesthetics into their Muslim dress. Tarlo argues, through referring to particular case studies, that looking Muslim is not always a case of conforming to an inherited tradition and that Muslim looks can be a way to negotiate multicultural backgrounds. Here she considers in detail two Muslim hip-hop artists called Poetic Pilgrimage.

Chapter five looks at the radical political organisation Hizb ut-Tahrir, addressing the multiple attempts by media representations, radical and conservative Muslim groups, and far-right British 
groups to place women's dress at the 'centre of a mythological 'clash of civilizations' (p.14). Tarlo considers her analysis of the media in the following chapter and questions how it is that face-veiling has become such an emotive issue and why it generates such affective responses. She examines the different meanings of the niqab through analysing different women's experiences - both of wearing the niqab and engaging with those who do, and looks at online discussions. The analysis of the internet is continued in chapter seven wherein Tarlo looks at the website thehijabshop.com in considering the role of fashion commerce in understanding the visual elements of religion. Next, Tarlo expands on this to consider Islamic fashion designers in Britain focusing on the role these designers play in generating cosmopolitan fashion for British Muslims by drawing together a multitude of regional global styles.

The book is full of pictures to emphasise Tarlo's points regarding the diversity of Muslim image and to highlight the direct engagement she has had with the communities she discusses. The brief afterword highlights how, since the manuscript was finalised, she has come across several blogs and online fashion stores showing even more shifting styles and emphasises that the book's crucial contribution is to highlight how fluid expressions of Muslim identity are, that fashions are ever changing and as such resist reductive generalisations.

\section{MAKING A NON-WHITE AMERICA: CALIFORNIANS COLORING OUTSIDE ETHNIC LINES,}

\section{5-1955,}

\section{Allison Varzally}

Publisher: University of California Press, Berkeley, Los Angeles and London

Year: 2008

Pagination: pp. 305

ISBN: 9780520253452

Price: $₫ 17.95$

This study looks closely at multiethnic neighbourhoods in California to examine the everyday encounters and interactions among diverse neighbourhoods comprised of Asian, Mexican, African, Native American and Jewish American people. Neighbourhoods with eclectic populations, argues Varzally, developed pan-ethnic understandings that acted as the foundation for multiethnic civil rights activism. Varzally has drawn on many primary sources for her argument: interviews, memoirs, personal papers, court records and newspapers.

Varzally explores how the desire for a multicultural society played out through interactions between minority groups; and how these interactions were not always successful. Though there were many interactions between groups that actively crossed cultural lines, there were also reservations regarding mixing between certain groups, and that relative similarities or differences in the various disadvantages affected how people interacted. As such these associations were constantly shifting due to the ongoing changes in marginalisation caused by White racism.

Chapter one explores the context that encouraged interethnic mixing in California by outlining how the impact of arrival of new immigrants accentuated diversity. She also charts how ethnic identity was formed and constructed through migration processes. After this follows an investigation of the role of youth culture in inter-ethnic mixing before World War Two, wherein Varzally considers the different approaches of young people to an interracial peerage. Highlighted are instances where children's enthusiasm for cross cultural interaction provoked their parents to look beyond isolation alongside instances where this enthusiasm was hindered through an insistence on adherence to ethnic conventions, cultural choices and a fear of disapproval, elucidating how some had a stronger separatist approach.

Chapter three looks at the cases of intercultural families and marriages between minorities as well as marriages of minorities with Whites. Here Varzally identifies the uniqueness that came from minorities mixing with minorities - as neither could offer the advantages that Whiteness could, each put forward the strengths of their own cultures which meant more balance than one partner bringing more privilege to the relationship. Next, Varzally asks what impact wartime stresses and conflicts had on minority interaction, considering this through examples such as the Zoot Suits Riots and the Japanese internment that exposed the ethno-racial prejudice of America. She uses such examples 
to highlight how these made minorities reconfigure how they saw California, and also realise more keenly the misfortunes they shared with other minorities.

In Chapter five, Varzally brings a broader perspective into this discussion by identifying the renewed vigour experienced by minority soldiers who served beyond California and so saw different forms of cross-cultural interaction - presenting the argument that they engaged with injustice in a broader way and became more attuned to White racism. In the final chapter, she looks at how informal connections across minority groups moved into politics and shaped civil rights, and considers coalitions that were unsuccessful, largely due to reservations already outlined, but also engages in detail with the successes of close networks of neighbourhoods. Throughout her book, Varzally aims to analyse mechanisms of Whiteness and privilege, engage with theories of immigration and assimilation and the larger framework of citizenship in 'multidescent nations', in order to highlight ways of negotiating belonging in a heterogeneous society.

\section{HISTORY}

\section{EMPIRE, DEVELOPMENT AND COLONIALISM: THE PAST IN THE PRESENT}

\section{Eds. Mark Duffield and Vernon Hewitt}

Publisher: James Currey, Woodbridge and Rochester

Year: 2009

Pagination: pp.211

ISBN: 9781847010117

Price: $\mathbf{4 5} .00$ (hardback)

This collection aims to explore 'the similarities and differences between contemporary debates on socio-economic development, humanitarian intervention and aid and the historical artefacts of European empire' (p.1). Duffield and Hewitt are keen to examine what can be revealed through looking at the repeats of past discourses of colonialism within present debates on development.

Co-editor, Matthew Merefield focuses on the Morant Bay Rebellion of 1865 in colonial Jamaica. Here liberal governmental strategies were promoting the freedom of slaves but maintained a racist view that the African body must still be disciplined as it was not capable of being rational. Merefield goes on to draw parallels with immigration policy and international development strategies. Vernon Hewitt compares the use of the term 'good government' in contemporary Britain and its past use in the colonial empire. Hewitt looks at the origins of the term to analyse how it originated and thus what assumptions it may still carry as a strategy of power.

Henrik Aspengren examines early twentieth-century Bombay and colonial governance to highlight the shift towards a vocabulary of social reform. This shift meant an embracing of liberalism yet continued to resist the political participation of Indian people. In his chapter, Suthaharan Nadarajah looks at the post-2002 ceasefire in Sri Lanka to consider the West-led conflict sensitivity codes of practice that were put in place to aid peace. Nadarajah argues that these western models of state structure that are imposed by development agencies actually cause conflict.

Richard Sheldon examines how colonial lands were portrayed as backward lands of famine in order to justify domination. Sheldon goes on to question what legacy this leaves for the present in terms of developmental intervention, especially in terms of famine. Subsequently, Lisa Smirl challenges the ethical neutrality of post-disaster intervention and compares this to the spatial policies of colonialism. She pays special attention to the status and power difference between Nongovernmental Organisations (NGOs) and local groups and their volunteers.

David Williams and Tom Young highlight colonial aims as a civilising mission; identifying similar language in development that is administered by the British State. They go on to point to domestic strategies that discipline and civilise though the nation state. Then, co-editor, Mark Duffield turns his attention to the colonial method of indirect rule and compares this to current intervention into 'fragile states'. He argues that both of these utilise discourses of security and are dependent on keeping power away from indigenous people.

Patricia Noxolo examines the racial anxiety and fear that mean bodies must be contained in 
some way even within discourses of freedom. She considers the emancipation of slaves that was enacted through denying them agency and compares this to the displaced people being contained in the name of humanitarian aid. April R. Biccum frames Empire as a form of politics that continues today and argues that any discussion of development has notions of empire at its centre. She posits that the prevalent idea of there being a historical rupture since the height of empire masks the continuities that are simply being expressed through different means.

Uma Kothari reviews the factors that were considered for colonial recruitment and sees a striking similarity between this demographic and those recruited into international volunteering today. She considers factors such as class and the cultural knowledge of adventure in more depth.

Douglas $\mathrm{H}$. Johnson focuses on the Sudan and the relationship between ethnic territories ad national development. He draws links between Britain's southern policy, the isolation of the south after independence, and the failure of nationalist development. Paul Kelemen looks at how left wing writers incorporated a critique of how the 'traditional life' of Africans was being eroded by capitalist influence, but also an expectation that the British governments needed the colonial enterprise to 'prepare them for the modern word' (p.5).

The chapters in this volume explore how humanitarian and liberal interventionism can echo and continue forms of governance expressed by European empires; the collection also highlights a crucial contradiction within the liberal project - the assertion and simultaneous denial of universal emancipation.

\section{BESA: MUSLIMS WHO SAVED JEWS IN WORLD WAR II \\ Norman H. Gershman}

Publisher: Syracuse University Press, New York

Year: 2008

Pagination: pp.125

ISBN: 978 o 815609346

Price: $£ 33.50$ (hardback)

In this book, photographer Norman Gershman collects stories and photographs of Muslims who, at great personal risk to themselves, sheltered Jews from the Nazis before and during the German occupation of 1943-44. In the foreword, Mordecai Paldiel outlines the significance of the book's title Besa, an Albanian code of honour that is coupled with the Albanian folk principle that one provides refuge to others when in need. This code of Albanian culture was intertwined with Islamic belief in compassion and mercy, which led to the prominent role of Muslims in Albania and Kosovo in sheltering Jews who were fleeing the Nazis.

In his introduction, Akbar Ahmed emphasises the importance of documenting these stories in 'fostering dialogue and understanding between Jews and Muslims' (p.xv). Ahmed emphasises how this humanitarianism in Albania was an enactment of Islamic faith, by saving Jews people were being good Muslims. The preface also outlines how '[s]urvivors relate that Albanians vied with each other for the honour of sheltering the fleeing Jews, a phenomenon unheard of in other European countries under the heel of the Nazis' (p.xiii).

The book is photography and part-ethnographic. Gershman visited Albania many times in putting this book together, interviewing many surviving partisans and their families. Through collecting stories, artefacts and photographs together, this book acts as a document of interpersonal and interfaith connections and compassion.

The text is comprised of fifty-eight portraits, with accompanying story/text/narrative detailing the person pictured. Across these narratives the consistent generosity and sacrifice made by those who had sheltered Jews is made clear. There are many direct narratives but some are of people recounting what their parents or grandparents did: Kujtim Civeja reads an extract from his family's diary, this charts how the family sheltered Jews and when the Germans came hunting down partisans and Jews, they all escaped together to the mountains to take refuge with an uncle there; and the son of King Zog and Queen Geraldine recounts how his father the king issued 400 passports to Jews fleeing the Germans in 1938. His father was the only Muslim ruler of a European nation. 
What is consistent among all is the belief in the strong bonds between Judaism and Islam in terms of history and origin. Many talk of the honour they felt in providing shelter, and in the words of Petrit Kika, the Muslims and Jews are 'old friends' (p.36). The term Besa also comes up frequently, people express their reasons for helping in these terms - that they live in the tradition of Besa. Ismet Shpuza explains that it 'seems strange to be asked why my father did what he did for this Jewish family. Besa is a tradition of the entire nation of Albania' (p.44).

The context of present day Albania is also mentioned, many talk of the years of communism and how this has impacted on how they practice Islam, though their faith remains strong. Those interviewed also discuss whether they are still in touch with those they sheltered, many citing the Albanian Israeli friendship Association as a way in which they have regained contact.

Gershman gives more details of the process of carrying out these interviews in his afterword, which outlines how he travelled with a driver, interpreter, and a guide from the Albanian Israeli Friendship Association.

\section{FIGHTING FOR BRITAIN: AFRICAN SOLDIERS IN THE SECOND WORLD WAR David Killingray (with Martin Plaut)}

Publisher: James Currey, Suffolk

Year: 2010

Pagination: pp. 289

ISBN: 9781847010155

Price: $f 55$ (hardback)

This accessibly written volume utilises oral testimony and letters to tell the story of Africans fighting in the British imperial forces during the Second World War. The book focuses on 'those who were black and who came from what rather crudely can be called 'Anglophone' Africa' (p.1), and aims to be a people's history through the centrality of the accounts from the soldiers themselves. The introduction sets out the methodology deployed by Killingray in researching the book and also outlines the structure of colonial armies in Africa between 1939-1945. This section also outlines the deployment of African colonial troops whih was also undertaken by French, Belgian and Italian armies at this time.

In the first chapter, entitled 'Africa 1939', Killingray outlines the context of colonial Africa, showing which European countries had conquered which regions and charting the colonial armies in Africa from the early 1900s until 1939. The multiple roles of the colonial armies are discussed, from supporting the police to providing aid to nearby colonies. The chapter points to the rise of Italian fascism as a catalyst to the British modernising their African armies to better face an Italian invasion from the Italian colonies within Africa.

In the subsequent chapter, 'Recruiting', he discusses how men were recruited for a battle they knew very little about, and howthe majority of recruitment was done in poor areas with limited access to economic modernity and these people were mostly recruited via local rulers. The author also provides a definition of martial races that were encouraged to sign up. These decisions made using were racially-based assumptions about who would be most likely to adapt to obeying new rules. The chapter goes on to discuss the specificities of recruiting for the Second World War and looks in turn at the different regions of Africa.

In 'Army Life', attention is drawn to the many new experiences, people and attitudes soldiers were exposed to in the army, as well as a reference to the training and the part race played in defining rank. Discipline, institutional violence and punishments are discussed alongside the role language played in defining opportunities. Killingray discusses the various skill sets taught through army training, as well as hygiene conditions and food provision, pay, welfare services, sport, leave and education.

The following chapter, entitled 'Indiscipline, Strike and Mutiny' contains accounts of various mutinies, and addresses how armies drawn from different regions had specific responses to mutiny. Often unrests were articulated through strike action and the withdrawal of labour - mostly arising from the hardships of military conditions but also from a growing resentment at the racial discrimination within the forces. Killingray discusses how acts of indiscipline were frequent but generally quite minor. 
In 'War', Killingray runs through the military campaigns that utilised African troops and charts the journey of people and supplies, pointing to the war as the largest movement of African men overseas since the slave trade. He also outlines combat conditions, war casualties and the experiences of prisoners of war who were used in German and Italian propaganda films. In the following chapter, 'Going Home and Demobilisation', he explores the ways in which the war disrupted the colonial order, as well as providing a description of the post-war resettlement plans that were prepared in advance of the end of the war to limit anti-colonial unrest. Killingray argues that the hope of colonial administrations that Africans would go back to their rural lives after the war was mostly fulfilled even though not all veterans could access the employment schemes and training opportunities that were set up.

Finally Killingray presents the chapters, 'Ex-servicemen and Politics' and 'The Social Impact of War Service'. Firstly he continues his discussion from the previous chapter to show how veterans were, for the most part, reabsorbed into rural life. He notes how some became involved in political parties but that most of the post-war ambition was focused on family, development and education. He also considers the changes created through military service, and the cases when authority was challenged as a result. The volume concludes with a brief postscript by the author; a full bibliography including details of primary sources; and index.

\section{FIGHTING FOR DEMOCRACY: BLACK VETERANS AND THE STRUGGLE AGAINST WHITE SUPREMACY IN THE POSTWAR SOUTH}

\section{Christopher S. Parker}

Publisher: Princeton University Press, Oxford and Princeton

Year: 2009

Pagination: pp. 266

ISBN: 978 o 691140049

Price: $₫ 16.95$

This volume focuses on the experiences of African American soldiers who became active in the Civil Rights Movement in the American South after returning from fighting in World War TWo and the Korean War. Through setting up the notion of 'black republicanism', Parker argues that the relationship between military service and local political activism culminates from the experience of fighting for their country and battling racism within the military and the everyday occurrences of risking their lives in domestic struggles against White supremacy.

Parker uses both interviews and survey information to explore how international war impacts on local attitudes and behaviours in order to locate and highlight the vital role of veterans in the Civil Rights struggle. The crux of the argument is that 'war stimulated what ultimately proved an insatiable appetite for equality - especially among black Southerners' (p.xi), and that after sacrificing so much to fight for their country Black Southerners saw themselves as deserving of first-class citizenship.

In the introduction, Parker questions why Black Southerners were willing to risk their lives in challenging White authority, exploring both the sense of agency from fighting war and a realisation of their strengths as they had fought both 'the enemy' and institutional racism. He argues that fighting for the US generated a connection to the nation that in turn meant veterans wanted to be able to participate fully in it. Through the following chapter, he then sets up the historical background of African-American military service since the American Revolution. This discussion elucidates how military service was considered an advancement for the race and a way of gaining respect, and that Black Americans often wanted to fight for a country that treated them like second-class citizens in the belief that this would lead to benefits in post-war times.

Chapter Two develops Parker's discussion of 'black republicanism', where beliefs and values that drew on republican ideas - such as the normative institutional experience of the military - were developed to fit the Black experience in America. Here Parker argues that the republicanism that was developed through the military was used to challenge White supremacy.

In the two subsequent chapters, Parker looks at the war time and post-war return experiences of the veterans. Initially he uses in-depth interviews with African American war veterans that explore the meaning of military service, the experiences of racism within the institution as well as the confidence 
given by serving. He also looks at how engagement with different cultures generated a heightened awareness of the segregation in the South, via an enablement of a comparative outlook. He moves on to focus on the return of veterans to the South and their criticisms of America, arguing that the criticisms were always couched in republican rhetoric stating the belief that the sacrifices they made for serving should have helped them on their return - as individuals and their race as a whole. At this point, Parker's discussion focuses specifically on two war veterans, Aaron Henry and Charlie Sims, charting their involvement with war and subsequent engagement with activism

Next, Parker utilises the Negro Political Participation survey to compare insurgent attitudes between veterans and non-veterans in the South, to argue that veterans' military service made them more likely to resist the status quo. He argues that veterans were committed to change and compares the attitudes of those in the South to African Americans in other parts of the country to support his claim. Finally, he examines the risks entailed in insurgent behaviour and considers the methods of activism, questioning how far activists would go to achieve their goals. He also highlights how these goals were always in support of democratic processes; activism centred on voting to challenge White supremacy, and veterans insisted on using mainstream political processes on which to base their challenges.

The book concludes by maintaining that the specific achievements of veterans, and in particular their leadership, need to be inscribed into the history of the Civil Rights Movement. Appendixes include an outline of interview methodology used for Chapter Three, as well as profiles of veteran activists. The volume also contains a thorough index and many tables and figures pertaining to survey information.

\section{FROM FARMS TO FOUNDRIES: AN ARAB COMMUNITY IN INDUSTRIAL BRITAIN}

\section{Kevin Searle}

Publisher: Peter Lang, Oxford and New York

Year: 2009

Pagination: pp.232

ISBN: 9783039119349

Price: $₫ 32.00$ (paperback)

This study aims to be an intervention into the post-war history of Britain, tying together immigration and industrial production. The book is based on extensive interviews with Yemeni former-steelworkers in Sheffield and takes an engagement with racism, class oppression and resistance as its central concern. Searle sets out to explore how these themes link into a story of migration, and contextualises these into the broader history of post-war settlement in Britain.

The introduction outlines how Yemenis were the largest section of the Muslim community in Britain for much of the first half of the twentieth century; and that Yemeni labour had been used to facilitate the flow of industrial exports from Britain to the colonies, across Suez. Searle is keen to note the long history and contribution of Muslim communities to Britain. He also highlights how post-war migration was undertaken at a time when Orientalism (Edward Said's theory of western concepts of the Orient) was rife and generating many negative portrayals. The Yemeni workers that Searle interviews cite these depictions, as well as negative representations of the Suez war, among their earliest memories of being in Britain.

The introduction outlines the aims of the study, theoretical approaches to racism and life story methods. It also details the research questions of the project, stating how much the project's scope has been informed by the interviews.

Chapter one looks at the multiple reasons for migration and engages with experiences of the actual journey from Yemen to Britain. Searle outlines how these journeys were a shared history that has helped to define the group identity of the Yemeni migrants he interviewed.. Next, the book recounts the experiences of migrants after arriving. He documents how they were met by high levels of unemployment in the late 1950 and also states that there was a notable difference in employment patterns between African Caribbeans and Arabs and Pakistanis. Searle explores these differences through the frame of racism. 
In Chapter three, Searle considers how themes of racism and class intersected with the experiences of migrants when working - referencing how a racial division of labour was characterised by the upwards mobility of White people compared with the static roles of Yemeni people working on the same production lines. He looks at the formation of informal resistances against exclusionary practice that were enacted by Yemeni workers.

The subsequent chapter looks at how race and class structured time outside of work and demonstrates that workers had very little time spare time, and that such time was characterised by exhaustion. The amount of time worked highlighted how the Yemeni interviewed by Searle were keen to earn money in Sheffield in order to return home to Yemen.

The final chapter considers the broadening social context of economic crises in the steel industry, alongside feelings of cultural estrangement and the racialised discourse of the Thatcherite government. It looks at how these factors affected migrants and also highlights the role of community organisations in promoting welfare and workers' rights to those Yemeni who were now unemployed in Sheffield. The study concludes by considering its own limitations and pointing to future directions for research. It also includes an appendix of Searle's literature review.

\section{MIGRATION, IMMIGRATION AND THE REFUGEE EXPERIENCE}

\section{CHILDREN IN IMMIGRANT FAMILIES IN EIGHT AFFLUENT COUNTRIES: THEIR FAMILY, NATIONAL AND INTERNATIONAL CONTEXT, INNOCENTI INSIGHT SERIES \\ Donald J. Hernandez, Suzanne McCartney and Victoria L. Blanchard}

Publisher: UNICEF, Innocenti Research Centre, Florence

Year: 2009

Pagination: pp. 100

ISBN: 9788889129937

Price: $\$ 20.00$ (paperback), free to download

This report is based upon internationally comparable data collected on children of immigrant families. The research was undertaken in Australia, France, Germany, Italy, The Netherlands, Switzerland, the UK and US. The findings were put collated to urge governments to ensure participation, access to education and employment, access to housing and reduction of poverty for the children of migrants. The report indicates areas of success in social inclusion and integration, as well as pointing to areas that call for greater improvement.

The foreword outlines the reasons for the report and emphasises how the 'child immigrant population frequently exceeds the share of the adult population' and that 'children's situation and experience has been largely missing from the migration debate and from related efforts in data collection and analysis' (p.vii). The report aims to generate a deeper understanding of the diversity in social groups, living conditions and opportunities of children of migrants.

The Introduction discusses the goals of the report in more detail, and points to the importance of referencing the national and international context to the children of immigrants, as well as the need to invest in the prospects of children in immigrant families. The report compares the impact of a range of indicators between children of immigrants and children of non-immigrants. The introduction goes on to explain its approach to terms such as 'inclusion' and 'integration' and also outline the methodology and approach behind collecting the data that informed the report.

The report looks at a broad range of factors and experience components, as well as examining the historical context of migration to the countries being studied, pre and post World War Two and more recent changes in policy and pattern. Factors examined include: inclusion of children of immigrants to societies at large; increasing immigrant populations coupled with aging native populations - and the prominent role children of immigrants have to play in socio-economic life; social inclusion in the area of education, and a comparison of engagement between children of immigrant and non-immigrant parents; civic participation through parents' citizenship, children's citizenship and immigrant generations. Also considered are factors relating to family life such as family size, the education levels of parents and their work situation, housing, residential overcrowding and home 
ownership. The importance of language and bilingualism is given special attention - in particular the pattern of bi- and multi-linguism and decisions about languages spoken at home. The authors also look at the role of government support to alleviate poverty and social transfer support, health status - including psychological adjustment and identity.

The report includes detailed figures and tables throughout. A series of Innocenti Working Papers have been published that review the literature pertaining to children of immigrant families in each of the countries studied.

\section{MOVEMENTS, BORDERS, AND IDENTITIES IN AFRICA Touin Falola and Aribidesi Usman (eds)}

Publisher: University of Rochester Press, Woodbridge and Rochester

Year: 2009

Pagination: pp.318

ISBN: 9781580462969

Price: 145 (hardback)

This collection investigates the causes and effects of migration and border crossings, population displacement, and shifting identities within Africa. The volume sets out to consider the variety of different forces that have acted on migrations and the development of states and societies that include 'slavery, commerce, gender, religion, colonialism, poverty, and development' (1). It discusses how migrations and population shifts have varied in being forced or voluntary depending on context. In their introduction, Falola and Usman highlight the slave trade as the most common form of international migration, and then outline other multiple reasons that can exist for migration - both internal and international - in Africa. They emphasise the substantial scale upon which this has occurred numerous times within the history of the continent, thus setting the tone for the collection as they seek to emphasise that population movements 'can best be understood within the context of the political and historical evolution of African societies' (p.2).

The introduction charts migration patterns across history, looking in turn at the pre-colonial, colonial and postcolonial periods. The editors emphasise how the specific and different conditions of each of these eras informed differently motivated migrations and also looks at female migration, identifying the multiple reasons for gender-based migration to resist making homogenising claims. The remainder of the volume is split into two sections: 'State Formation and Migration Crossroads' and 'Movements and Identities'.

The Chapters in the first section look at two migrations - of the Osogbo in southwest Nigeria followed by that of the Yoruba. The Osogbo analysis is based upon oral history and archaeological evidence and acts as a challenge to the assumptions made by Igor Kopytoff regarding the nature of the internal African frontier. The examination of the Yoruba incorporates consideration of the origins of pan-Yoruba ethnicity and its connections to population movements and Ile-Ife utilising an analytical approach to the relevant history and assessing how archaeological artefacts might contribute information regarding population movements. Chapter four provides a chronological analysis of regional migrations of Yoruba and considers the challenges of taking an archaeological approach, whilst presenting the benefits from the details held within artefacts that can point to dominance of certain cultures over others.

Chapter five considers the different social forces that informed nineteenth and twentieth century 'Afro-Brazilian' architecture in Lagos; and analyses this hybrid architecture as a result of returned slaves expressing influences of places where they had been enslaved.

In the section entitled Movements and Identities, the editors include chapters that look at other migrant communities. Firstly, they investigate the impact of rural-urban migration on informal settlements such as squatter camps and slums and focuse in particular on the role of a shantytown in Mamelodi, South Africa in terms of supporting migration; which is followed by chapter concerned with analysing the population displacement that occurred during colonial conquest as a result of divide and rule. The displacement of the Jo-Ugenya of western Kenya into a permanent migration once their territories were taken over by rival groups, is cited as an example of this. 
In chapters eight and nine, the collection shifts its attention to the experiences of the Hausa Diaspora in Ghana and the role of the Hausa as soldiers and traders, as well as the forced colonial migration of the Madheruka to the Gowke region of Zimbabwe. This forced migration occurred due to their experience of cotton farming and the impact this had on the ethnic identity of the indigenous Shangwe.

Next the book turns to fiction and looks at The Suns of Independence (1968) to consider the legacy of forced labour migrations, in particular how the Ivory Coast needed cheap migrant workers to replace the forced labour that had been sent away as a result of independence. Chapter eleven widens the approach to look at intercontinental migration, addressing how the need for hometown-based associations evolved to help people survive in host cultures. In the next Chapter, the Swahili culture on the coast of Kenya is considered. This includes an examination of how traumatic experiences of slavery have had varying effects on identity production, including an internalisation of oppression that means people would rather identify with slave owners than Africans. The last chapter unpicks the impact of taxation and forced labour by French colonisers and considers how this led to people migrating to work for private operators of cocoa farms outside of the colony.

\section{POLITICS AND GOVERNMENT}

\section{WAVES OF DECOLONIZATION: DISCOURSES OF RACE AND HEMISPHERIC CITIZENSHIP IN CUBA, MEXICO, AND THE UNITED STATES \\ David Luis-Brown}

Publisher: Duke University Press, Durham and London

Year: 2008

Pagination: pp.340

ISBN: 978 o 82234366 o

Price: $₫ 13.99$ (paperback)

The focus of this volume is writer-activists in Cuba, Mexico and the US who made connections between their local civil rights struggle and anti-imperialist thought with struggles in other nations. These writers, acting from the 1880s to 1930s, aimed to reconceptualise the notion of rights to consider their losses under the expanding empire of the United States.

Taking as his departure point an engagement with W. E. B. Du Bois, Luis-Brown highlights the links being made by him between those being subjected to the US's imperial policy and African Americans. For Du Bois, particularly in relation to the Spanish-Cuban-American war of 1898, US imperial expansion meant people of colour would be victimised, thus creating the need for alliances , across a 'global color line' (p.3). Luis-Brown uses the term 'decolonization' to refer to these alliances that put in place anti-racist and anti-imperial movements; as well as reconsidering geographies and temporalities through identifying local struggles with global movements against imperialism and historical movements of the same.

The book sets out to explore these connections further and analyse how writers other than Du Bois articulated similar resistances. The cross-national scope of the writing Luis-Brown aims to explore demonstrate a commitment to transnational and inter-ethnic exchange and coalition; where an analysis of imperialism sheds light on domestic racial inequalities, writings on race also contribute to cross-national understandings of decolonisation. The book focuses on the role of the Americas in decolonisation and uses decolonisation as an analytical frame to link writers in the US to those in Cuba and Mexico.

Luis-Brown argues that these links across nations and history demonstrate the attempts of writers to enact an alternative form of citizenship, or 'hemispheric citizenship', which acknowledges the new meanings citizenship, takes on due to the fluxes in nation geography, for both imperial subjects and citizens of the imperial state. The focus of the book is marked out through identifying two waves of decolonisation, 1880s-90s and 1920 s that 'roughly coincide with the age of PanAmericanism, an institutional and ideological project defined by US efforts to gain economic control 
over Latin America' (p.7).

In the first chapter, he analyses Helen Hunt Jackson's Ramona and Maria Amparo Ruiz de Burton's The Squatter and the Don to consider sentimental melodrama and romantic racialism as structural forms in these texts. He asks what effect these structures can have on the representation of imperialism and expression of decolonisation. Following this, Luis-Brown engages with the works of José Martí who was writing C. 1889 and returns to W. E. B. Du Bois work of the 1920 s and his book Darkwater. The discussion unpicks their attitudes towards the image of the US as a nation of liberty and the global impact of this image and the chapter is concerned with drawing links between their attitudes regarding race and empire across the two generations.

Chapter three highlights the crossover between movements in the 1920 such as the Harlem Renaissance, Mexican indigenismo, and Cuban negrismo movements. These ties occurred across national, ethnic and religious lines and drew on similar discourses of primitivism that Luis-Brown identifies as a transnational move that develop a political affinity between these identities. He also looks closely at three texts: Claude McKay's Home to Harlem, Menéndez's Nayar, and Masdeu's La Raza Triste. Subsequently he extends the argument from chapter three into the next by considering the influence of Franz Boas on both the Harlem Renaissance and Mexican indigenismo - given that Boaz delivered seminal lectures and mentored key writers at this time. Luis-Brown also draws connections between sociologist Robert E. Park and his influence on both nationalisms. In his afterword, the author emphasises his focus on the forging of links between seemingly distinct histories through his exploration of 'waves of decolonisation'.

\section{GANDHI AND THE MIDDLE EAST: JEWS, ARABS AND IMPERIAL INTERESTS Simone Panter-Brick}

Publisher: I. B. Tauris, London and New York

Year: 2008

Pagination: pp. 193

ISBN: 9781845115845

Price: $£ 47.50$

Gandhi's belief in non-violence is at the centre of Simon Panter-Brick's historical account of his involvement in Middle Eastern politics. Through studying a collection of Gandhi's letters that were only recently discovered, this book traces both his conviction that non-violent peace was attainable, and the failure of his ideals to come into being. The book takes a chronological approach and begins by charting how Gandhi first became involved with politics in the Middle East through fighting for the continuation of Ottoman Caliph's jurisdiction over Palestine.

The book makes the case that many of Gandhi's opinions regarding Palestine were informed by an understanding of the comparisons that could be drawn between Palestine and India. While he opposed partition in India he also could not support it in Palestine and so became adamant that Palestine should not be divided - but he also wanted to prevent the marginalisation of the Jews. The letters also provide further evidence of the connections felt between Indian Muslims and the situation of Muslims in Palestine, with demonstrations against the Balfour Commission being held in India in 1937. Gandhi, being understood as pro-Arab in the context of partition in Palestine, is seen by Panter-Brick as helping his domestic political situation for demonstrating support for Muslims. Panter-Brick also argues that Gandhi drew many comparisons between Jews and 'untouchables' (very low-caste and marginalised Hindus), seeing both as marginalised groups that needed to be allowed to participate in mainstream political arenas rather than be separated - again enforcing his resistance to partition in Palestine. Charting the historical trajectories that lead to shaking off British rule and subsequent partitions in India and Palestine, Panter-Brick draws links between the two to highlight the role of Gandhi as a political negotiator.

The book goes on to discuss in more depth Gandhi's characteristic priorities in politics: his commitment to non-violence, to Hindu-Muslim unity, to independence from colonial rule and greater rights for 'untouchables'. The volume also explores Gandhi's character as it was evidenced through his politics. Panter-Brick's study highlights the contradictions in Gandhi's opinions regarding Palestine 
and Muslim and Jewish claims to sovereignty, in order to draw attention to his constantly evolving opinions and make the claim that it is intellectual honesty that led Gandhi to always speak his mind regardless of whether this was consistent with previously expressed thoughts. She also explores how ambivalent the term non-violence could be for Gandhi in that he often tolerated violence even though he would never advocate it. Where he argued for non-violent measures to be upheld in Palestine, Panter-Brick explains how he was seen by Jews to be excusing violence by Arabs as a justifiable response to invasion. However, his insistence remained that in upholding a non-violent campaign the support of the world could be ensured. To Gandhi, non-violence expressed bravery, and, whatever the outcome, was worth the risk of a negative outcome, as it allowed for the ability to be morally superior and gain or retain the favour of public opinion. In conclusion, Panter-Brick argues that Gandhi's relationship with Palestine was akin to a love affair, and his love of the place led him to advocate non-violent methods; but ultimately, as with all great love affairs, it did not end well.

Overall, this study charts the trajectory of developments in both the Middle East and India to identify Gandhi's shifting roles and opinions in relation to the two struggles. The book works to highlight points of convergence and divergence between these contexts and Gandhi's place in between. This approach aims to makes sense of his differing opinions and how these changed. The book concludes with appendixes of a ballad about Gandhi, a letter he wrote for the magazine Harijan regarding Jews in 1938 where he compares then to 'untouchables'; and his article 'Jews and Palestine' in 1948 for the same magazine.

\title{
SOCIAL THEORY
}

\author{
DARKER THAN BLUE: ON THE MORAL ECONOMIES OF BLACK ATLANTIC CULTURE \\ Paul Gilroy \\ Belknap Press, London and Cambridge, Massachusetts \\ Year: 2010 \\ Pagination: pp. 207 \\ ISBN: 978 o 674035706 \\ Price: $₫ 16.95$
}

The three chapters that make up this book were initially presented as the W. E. B. Du Bois lecture series at Harvard. Gilroy aims to make suggestions that could lead to the revitalisation of African American studies by promoting a stronger relationship with contemporary critical thought and engaging with Du Bois in a more unconventional way. Each chapter sets out to address a particular issue that the politics of race, racism and Blackness have altered and been altered by.

In 'Get Free or Die Tryin", Gilroy considers consumer culture, examining how the culture of freedom that was generated through the overthrow of racial slavery has been utilised for commerce. Here Gilroy expresses a need for us to consider how capitalism and commerce were key factors in the slave trade where people were treated like any other commodity and that as consequence the Black person has become just an object in the midst of objects.

'Declaration of Rights' analyses the contestation of human rights, looking at the ways in which the ideas of freedom discussed in chapter one articulate themselves through rights discourse. Gilroy begins by highlighting how 'struggles against racial or ethnic hierarchy are not usually viewed as an important source for human rights movements and ideologies' (p.55). He argues that human rights developed in an uneven way and that struggles against racial hierarchy are actually crucial to how we have come to understand the human. The discussion engages with writers such as Giorgio Agamben, Primo Levi, Hannah Arendt and Michel Foucault to challenge the disinterest in abolitionist struggles shown by chroniclers of human rights struggles.

'Troubadours, Warriors, and Diplomats' unpicks geo-politics and the subsuming of AfricanAmerican cultural production into Americana to consider how the Black Atlantic is embedded in the discourse of the 'War on Terror'. Gilroy makes a stark comparison between Bob Marley, James Brown and Curtis Mayfield, and the contemporary music 'brands' such as Jay-Z, positing that music used to be made for freedom but has developed into a new meaning of freedom equating to consumption 
as the satisfaction of all desires. The chapter ends with a discussion of the racism of the US state and its connections to histories of colonial warfare, and a consideration of the current interpretation of freedom in the political climate given the prominent political presences of Condoleeza Rice and Barack Obama.

Overall this collection explores African American intellectual and political legacies alongside the place of Black culture in today's political and economic climate. Gilroy traces the shifting characters of Black intellectual and social movements to question the reach of the global force of Black cultures that have been drained of their moral message for global justice.

\section{Muslim Spaces of Hope: Geographies of Possibility in Britain and the West Edited by Richard Phillips}

Publisher: Zed Books, London and New York

Year: 2009

Pagination: pp. 271

ISBN: 9781848133013

Price: $₫ 19.99$

This extensive and interdisciplinary collection incorporates fourteen chapters examining what Muslims have to be hopeful about in the contemporary political climate, and challenges assumptions that are frequently made regarding Muslims and the West. These discussions are located within the wider constructions of race and identity to make larger points regarding social difference and colonial histories. The collection aims to highlight what problems Muslims face in order to resist popular discourses that identify Muslims as a problem, and to create positive and hopeful ways to move forward.

The book's introduction outlines a series of Muslim geographies and engages with the politics of location. It also addresses the issues of the poverty experienced by many Muslims across the UK and US due to the geographical spaces they inhabit offering suffering socio-economic deprivation. Further, it outlines the basis for the collections discussions of the notion of the 'West', imperial binaries of East v. West, and Muslim v. Christian that are used to define this conceptual space.

The subsequent chapters are divided into four sections:

'Spaces of hope?' introduces the major themes including Sardar's challenge to the very assumption that segregation is negative and integration always positive, arguing that these terms are contextually contingent. Following this Hopkins elucidates the problems with the notion that categories of 'Muslim' and 'West' must be considered as oppositional and Dunn and Kampo conclude this section by examining Islam in Australia.

'Convivial cities' focuses on more specific experiences of Muslims in Western urban cultural life; with Reina Lewis considering fashion, looking at how young Muslim women combine religious identity with fashion retailing. Sarah Mills then analyses the role of children in mixed cultural institutions, arguing the amount of integration evident in their engagement with civic life. Sibley and Faldi examine the role of the Islamic bathhouse, proposing that it extends an Islamic concept to the wider European world through welcoming people into its space. Datta continues the focus on space by looking at how housing in East London has been tailored to suit the needs of Bangladeshi communities.

'Economic and political empowerment' continues to look at specific experiences but in the context of economic and political life; Pollard, Lim and Brown's chapter demonstrate the empowering potential of Islamic financial systems for both Muslim and non-Muslim communities. Iqbal and Phillips look at the participation of Muslim activists in anti-war campaigns, considering this as an engagement with Western political space. Following this, Glynn analyses the responses of Western governments to the politicisation of their Muslim citizens.

'Integration and resistance' concludes the volume with Dwyer and Uberoi's look at the community cohesion debates of local government, followed by Brice's analysis of the census to examine integration through residential patterns. Sirin and Imamoğlu engage with Muslim-American youths to identify how they are finding harmonious ways to embody their hybrid identities and Abbas 
concludes the volume by examining the 'threats and opportunities' (p.252) within wider national government initiatives in the UK since the $7 / 7$ bombings in London.

The collection endeavours to 'recast [these geographies] as potential spaces of hope' (p6) and argues that identifying exclusions and deprivations provides the first steps towards locating the hope for a progressive and inclusionary politics within.

\section{THE INVISIBLE EMPIRE: WHITE DISCOURSE, TOLERANCE AND BELONGING, Georgie Wemyss}

Publisher: Studies in Migration and Diaspora Series, Ashgate Publishing, Farnham and Burlington

Year: 2009

Pagination: pp. 148

ISBN: 978 o 754673477

Price: $£ 55.00$ (hardback)

This engagement with Critical Race Theory (CRT) takes on ethnographic and discourse analysis to consider how any burying of the histories of Empire allows tropes of empire to be mobilised in the present, fixing British society within the violence of its imperial legacy. The book's title stems from Wemyss noting how histories of Empire are assumed to be irrelevant to contemporary international politics, such as the Iraq war. Wemyss argues that as a result Britain cannot offer 'belonging' to people of colour, and that central to this amnesia is a denial of the involvement of minorities in making Britain what it is today. The study looks at Western cultural hegemony through looking at notions of Britishness to show how this discourse maintains its power to exclude along race lines. In turn it discusses the intolerance that lies at the heart of discourses of tolerance purported by White liberals, arguing that 'tolerance' actually supports White-centricity. The study focuses on Bengali communities and London's East End.

The text begins with a personal introduction that outlines the author's specific experiences of racism and cultural assumptions made by White middle class families in her neighbourhood, outlining how these represent a dominant discourse of ideas about Bengalis, and more generally about multiculturalism. The main focuses of dominant discourse explored include how the history of Britain asserts particular histories while silencing other narratives. It is also noted how, when colonialism is mentioned, it is claimed as a civilising force. Theoretical approaches of Foucault and Raymond Williams are utilised to analyse discourse around Britishness and see how negative histories of empire - exploitation and racism - have been obscured. Here the core question is ' $[\mathrm{H}]$ ow does the absence of some histories of the British Empire, and the mobilisation of others, work to include or exclude different categories of people from the twenty-first-century British collectivity?' (p.12)

A discussion of Whiteness is also central to the overall argument and the assumptions of certain characteristics as White - such as being middle-class or English - are addressed. Further , it references how these assumptions both privilege and naturalise Whiteness, producing the counter- that Bengali or Muslim identities have also become homogenised. With this Wemyss aims to specifically 'investigate the processes through which White liberal discourse mobilises specific histories, normalises Whiteness and constructs different subjects' (p.11).

The book's is separated into sections that: outline the methodology and theoretical framework Wemyss deploys; provide a context for two geographical locations - Tower Hamlets and Docklands in London; and a history of commemorative events related to Empire (including highlighting evidence of ways those areas have excluded Ethnic Minorities from their histories in public presentation). Finally, the author addresses the racialised hierarchy of belonging to Britain, arguing that tolerance is used to maintain cultural hegemony. Here Wemyss analyses how South Asian communities have been excluded by this discourse of tolerance as well as by the British state.

The book concludes by considering how, through making the invisible visible, commonality and metropolitan belonging might be gained. 


\section{Ethnicity and Race in a Changing World: \\ A Review Journal}

ISSN 1758-8685

MANCHESTER
$\frac{1824}{\text { Manchester University Press }}$

MANCHESTER 